\title{
HYDROLOGY OF AREA 31, EASTERN REGION; INTERIOR COAL PROVINCE, ILLINOIS AND INDIANA
}

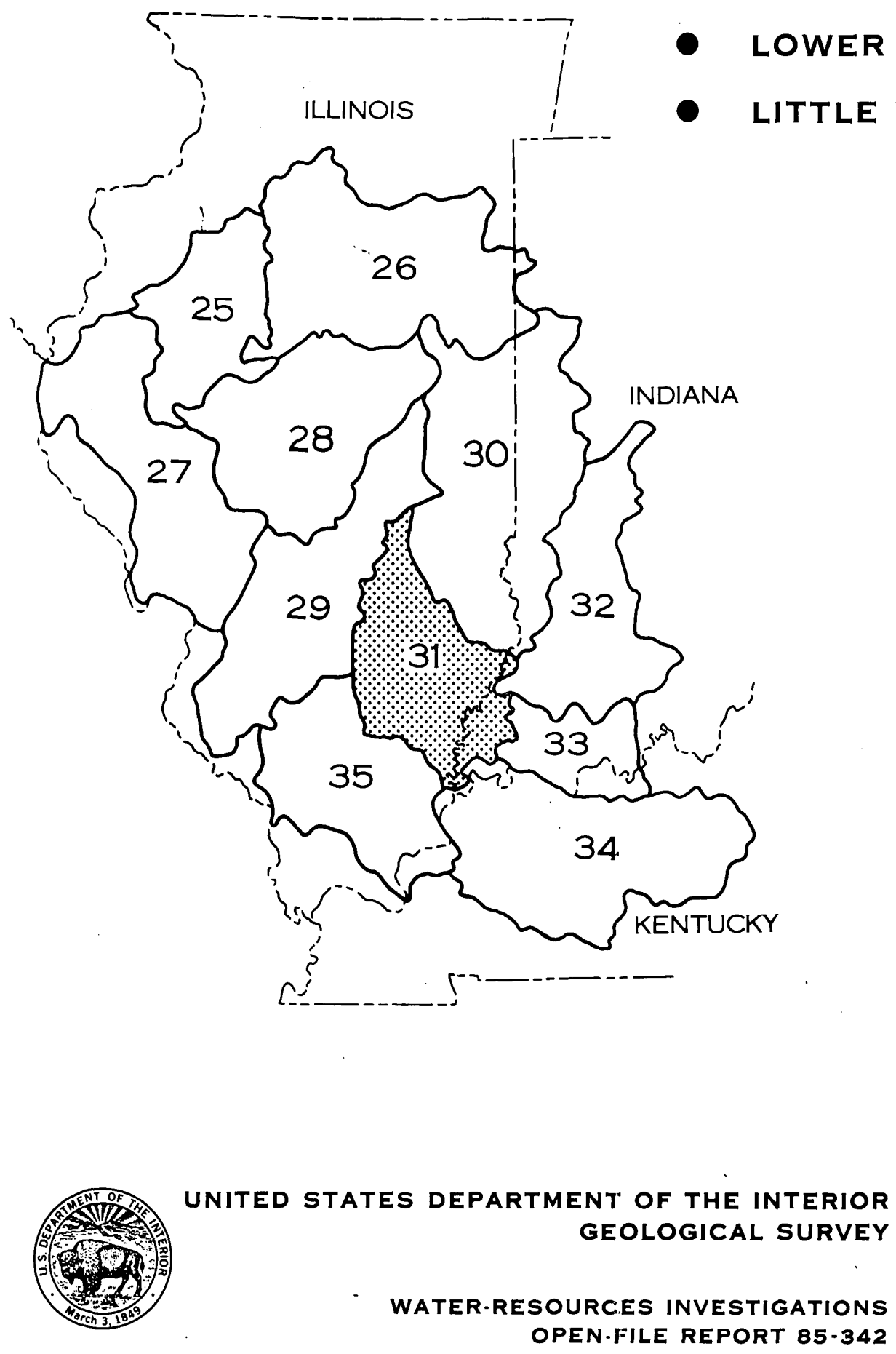




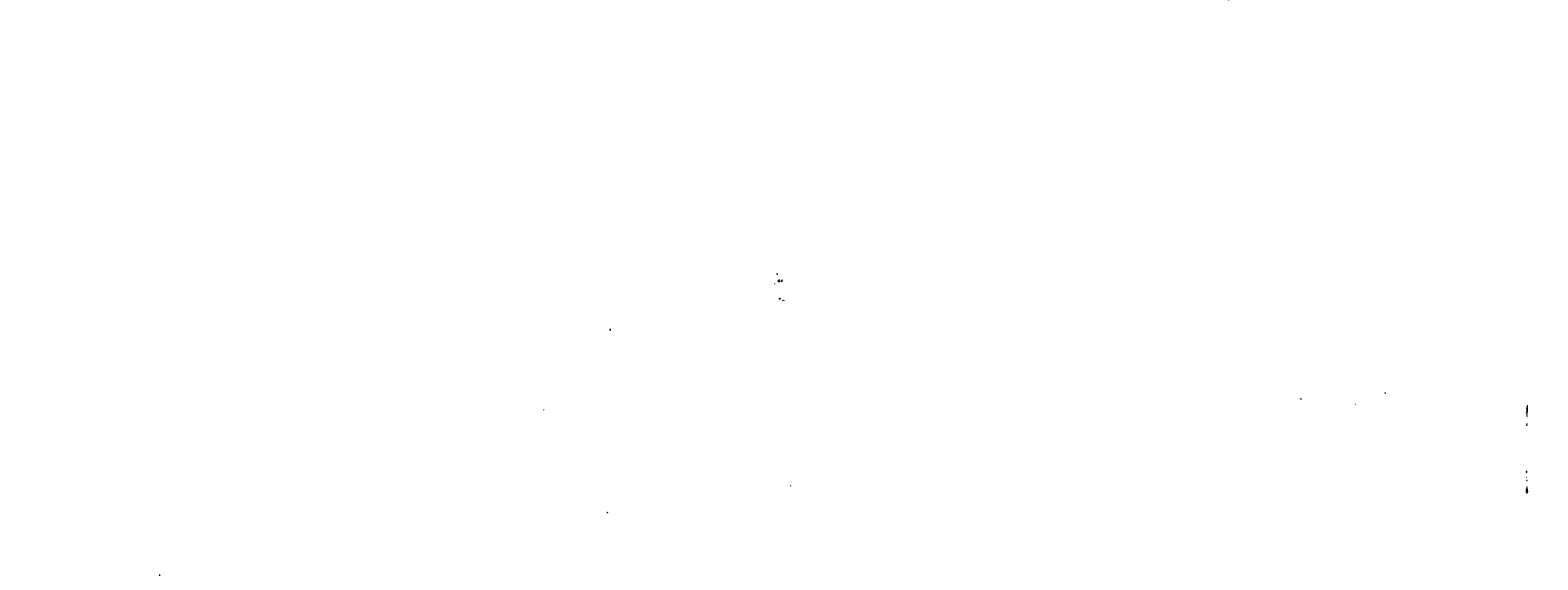
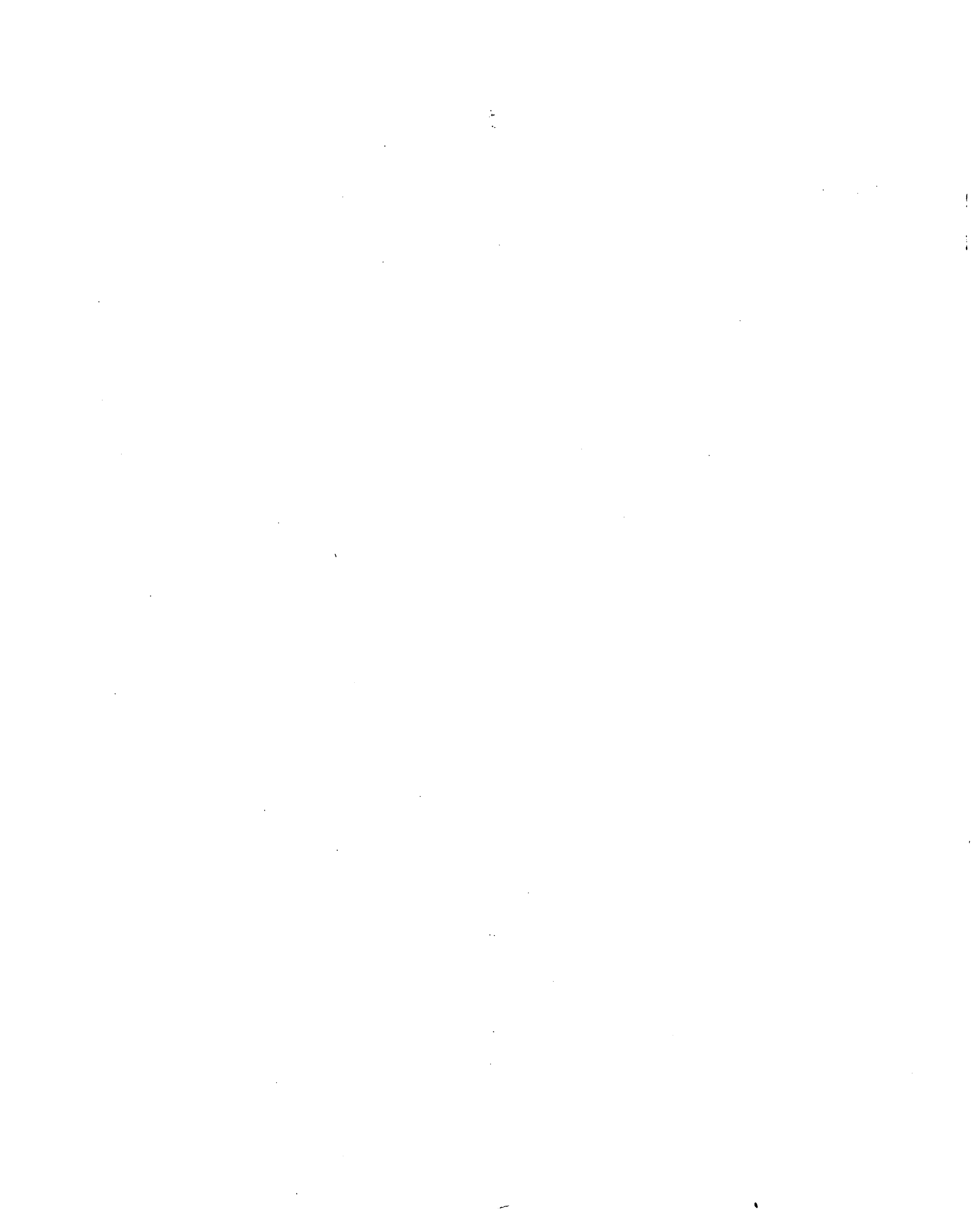


\section{HYDROLOGY OF AREA 31, EASTERN REGION, INTERIOR COAL PROVINCE, ILLINOIS AND INDIANA}

BY

E. E. ZUEHLS

U.S. GEOLOGICAL SURVEY

WATER-RESOURCES INVESTIGATIONS

OPEN-FILE REPORT 85.342

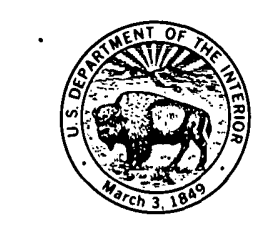

URBANA, ILLINOIS

JANUARY, 1987 


\section{UNITED STATES DEPARTMENT OF THE INTERIOR}

DONALD PAUL HODEL, SECRETARY

\section{GEOLOGICAL SURVEY}

Dallas. L. Peck, Director

For additional information write to:

District Chief

U.S. Geological Survey

Water Resources Division

Busey Bank County Plaza

102 East Main Street, 4th Floor

Urbana, Illinois $\quad 61801$ 


\section{CONTENTS}

Abstract

1.0 Introduction

1.1 Objective. .2

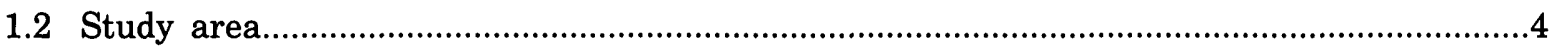

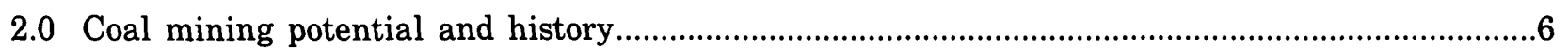

3.0 Geology

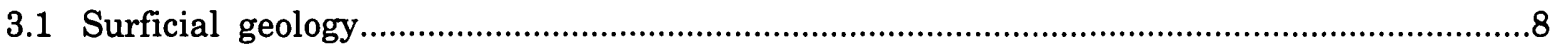

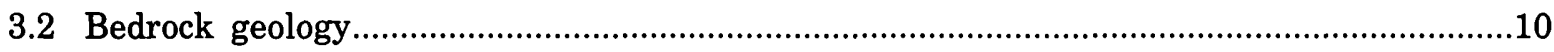

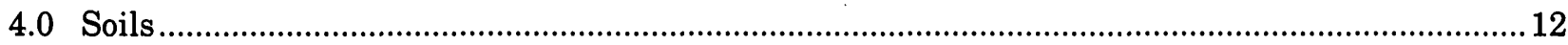

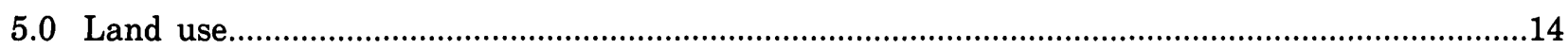

6.0 Water use

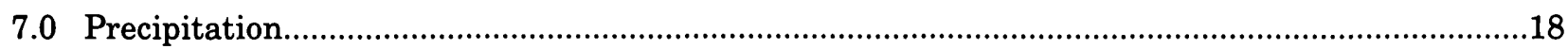

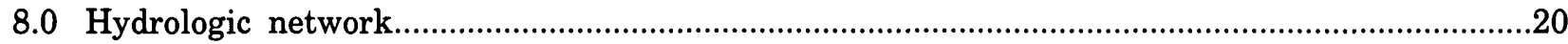

9.0 Surface-water quantity

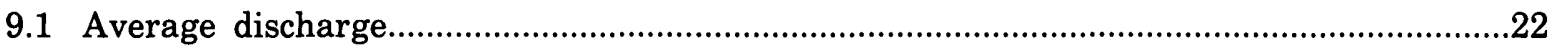

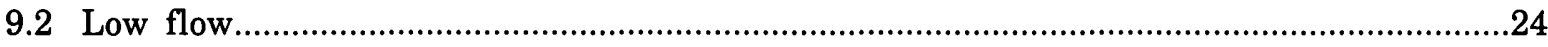

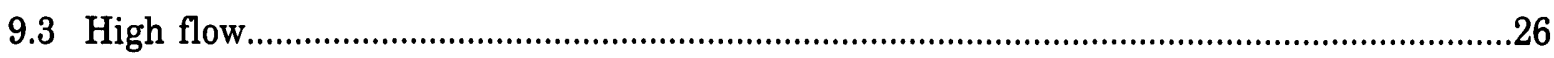

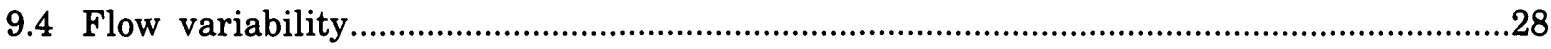

10.0 Surface-water quality

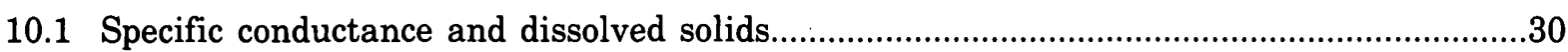

$10.2 \mathrm{pH}$

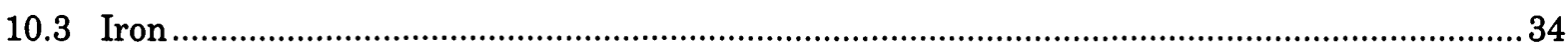

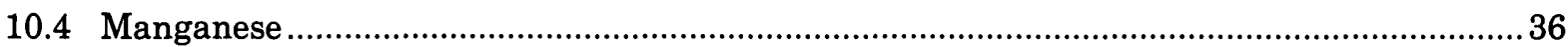

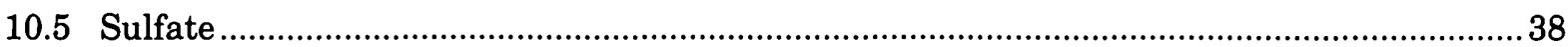

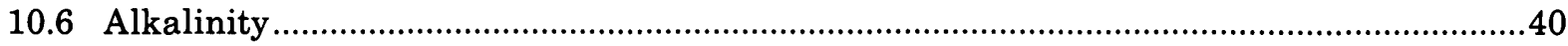

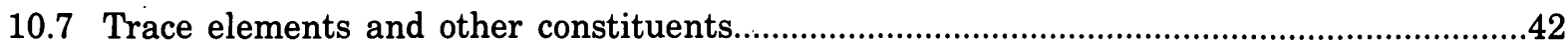

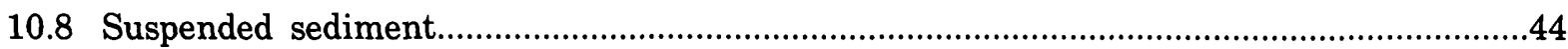

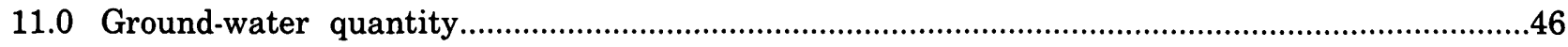

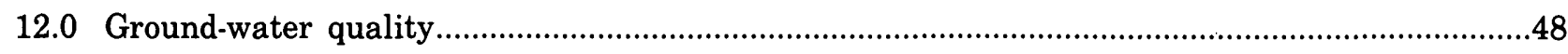

13.0 Water-data sources

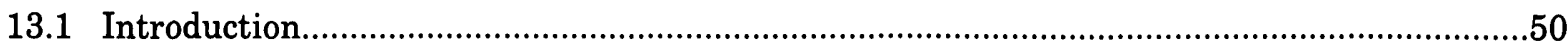

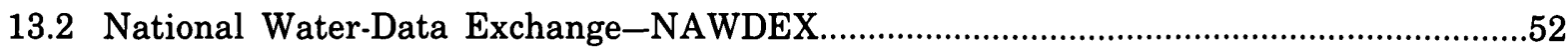

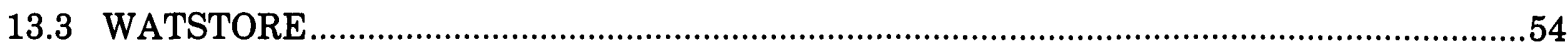

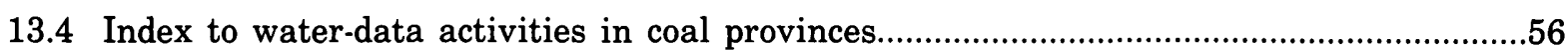

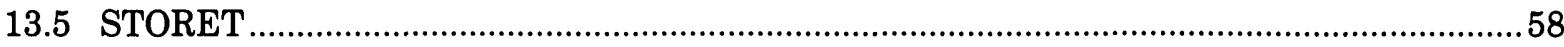

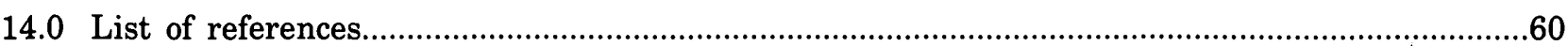




\section{CONVERSION FACTORS AND RELATED INFORMATION}

For the convenience of readers who may want to use the International System of Units (SI), the data may be converted by using the following factors:

Multiply inch-pound units

inch (in.)

inch per hour (in./h)

foot $(\mathrm{ft})$

foot per mile (ft/mi)

mile (mi)

square mile $\left(\mathrm{mi}^{2}\right)$

cubic yard $\left(\mathrm{yd}^{3}\right)$

gallon per minute (gal/min)

million gallons per day (Mgal/d)

cubic foot per second $\left(\mathrm{ft}^{3} / \mathrm{s}\right)$

cubic foot per second per square mile $\left[\left(\mathrm{ft}^{3} / \mathrm{s}\right) / \mathrm{mi}^{2}\right]$

ton per square mile per year [(ton $\left.\left./ \mathrm{mi}^{2}\right) / \mathrm{yr}\right]$

ton, short $\underline{\text { By }}$

25.40

25.40

2.54

0.3048

0.1894

1.609

2.590

0.7646

0.06308

0.04381

3,785

0.02832

0.01093

0.3503

0.9072
To obtain SI units

millimeter $(\mathrm{mm})$

millimeter per hour $(\mathrm{mm} / \mathrm{h})$ centimeter per hour $(\mathrm{cm} / \mathrm{h})$

meter $(\mathrm{m})$

meter per kilometer $(\mathrm{m} / \mathrm{km})$

kilometer (km)

square kilometer $\left(\mathrm{km}^{2}\right)$

cubic meter $\left(\mathrm{m}^{3}\right)$

liter per second $(\mathrm{L} / \mathrm{s})$

cubic meter per second $\left(\mathrm{m}^{3} / \mathrm{s}\right)$ cubic meter per day $\left(\mathrm{m}^{3} / \mathrm{d}\right)$

cubic meter per second $\left(\mathrm{m}^{3} / \mathrm{s}\right)$

cubic meter per second per square kilometer $\left[\left(\mathrm{m}^{3} / \mathrm{s}\right) / \mathrm{km}^{2}\right]$

metric ton per square kilometer per year $\left[\left(\mathrm{t} / \mathrm{km}^{2}\right) / \mathrm{a}\right]$

megagram $(\mathrm{Mg})$

Temperature can be converted to degrees Fahrenheit $\left({ }^{\circ} \mathrm{F}\right)$ or degrees Celsius $\left({ }^{\circ} \mathrm{C}\right)$ by the following equations:

$$
\begin{aligned}
{ }^{\circ} \mathrm{F} & =9 / 5\left({ }^{\circ} \mathrm{C}\right)+32 \\
{ }^{\circ} \mathrm{C} & =5 / 9\left({ }^{\circ} \mathrm{F}-32\right)
\end{aligned}
$$

The inch-pound units for reporting specific conductance micromhos per centimeter at $25^{\circ}$ Celsius are equivalent to the SI units of microsiemens per centimeter at $25^{\circ}$ Celsius $(\mu \mathrm{S} / \mathrm{cm})$. 


\section{GLOSSARY}

Alkalinity-In this report, it is the capacity of a solution to neutralize acid to $\mathrm{pH}$ of 4.5 .

Climatic year-A continuous 12-month period, April 1 through March 31; designated by the calendar year in which it begins and includes 9 of the 12 months.

Dissolved-That material in a representative water sample which passes through a $0.45 \mu \mathrm{m}$ membrane filter. This is a convenient operational definition used by Federal agencies that collect water data. Determinations of "dissolved" constituents are made on subsamples of the filtrate.

Dissolved solids-A measure of total concentration of dissolved minerals in water.

Flow duration-The percent of time a given discharge at a streamflow site will be equaled or exceeded.

$M_{7,10}$ low flow-The lowest 7-day mean discharge expected to be equaled or exceeded once in a 10 -year period.

$p H$-The negative logarithm to base 10 of the effective hydrogen ion activity in moles per liter.

Specific conductance-A measure of the ability of a water to conduct an electrical current. It is expressed in microsiemens per centimeter at $25^{\circ} \mathrm{C}$. Specific conductance is related to the type and concentration of ions in solution.

Suspended sediment-Solid material that originates mostly from disintegrated rocks and is transported by or suspended in water; it includes chemical and biochemical precipitates and decomposed organic material such as humus.
Suspended-sediment concentration-The concentration of suspended sediment in the sampled zone measured as milligrams of dry sediment per liter of the water-sediment mixture.

Suspended-sediment load-The amount of suspended sediment passing a section in a specified period.

Suspended-sediment yield-The suspendedsediment load divided by the drainage area.

Total recoverable-The amount of a given constituent that is in solution after a representative water-suspended sediment sample has been digested by a method (usually using dilute acid solution) that results in dissolution of only readily soluble substances. Complete dissolution of all particulate matter is not achieved by the digestion treatment, and thus the determination represents something less than the "total" amount (that is, less than 95 percent) of the constituent present in the dissolved and suspended phases of the sample. To achieve comparability of analytical data, equivalent digestion procedures would be required of all laboratories performing such analyses because different digestion procedures are likely to produce different analytical results.

$V_{7,10}$ high flow-The highest 7-day mean discharge expected to be equaled or exceeded once in a 10 -year period.

Water year-A continuous 12-month period, October 1 through September 30; designated by the calendar year in which it ends and includes 9 of the 12 months. 


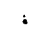

:

i 


\title{
HYDROLOGY OF AREA 31, EASTERN REGION, INTERIOR COAL PROVINCE, ILLINOIS AND INDIANA
}

BY

\author{
E. E. ZUEHLS
}

\begin{abstract}
This report broadly characterizes the hydrology of Area 31,1 of 11 study areas in the Eastern Region of the Interior Coal Province. This area was investigated to provide applicants for coal-mining permits, and regulatory authorities, general hydrologic information for determining the probable hydrologic consequences of any proposed mining.
\end{abstract}

ABSTRACT

Area 31 is located in southeastern Illinois and southwestern Indiana and covers about 4,500 square miles. Major streams in Area 31 are the Little Wabash River and the lower Wabash River. Agriculture is the dominant land use, 67 percent cropland and 9.8 percent pasture. Average annual precipitation ranges from 39 to 44 inches.

Glacial deposits overlie the bedrock, form the land surface, and are the parent material for most soils in the area. Pennsylvanian rocks underlie the glacial material and contain from 1 to 2 percent coal along with sandstone, limestone, siltstone, shale, and clay. The only operational coal mine, as of December 1983, removed about 2.5 million tons of coal from a depth of about 700 feet in 1982.

The U.S. Geological Survey operates a network of 33 hydrologic monitoring sites in the study area. Data from this network are available from computer storage through the National Water-Data Exchange (NAWDEX) operated by the U.S. Geological Survey.

Average streamflow, low flow, high flow, peak discharge, and flow duration values are available for 10 continuous-record gaging sites. Streamflow data are also available for 1 additional continuous-record gaging site, 10 crest-stage sites, 2 low-flow partial-record sites, and 8 sites where miscellaneous water-discharge measurements were made. Average streamflow, high flow, and peak discharge can be estimated at ungaged sites based on drainage area and stream channel slope.
Flow duration values indicate uniform streamflow characteristics for high flow but variable characteristics for low-flow. Sites with drainage areas of less than 240 square miles had a 7-day low-flow value of zero for all recurrence intervals of 5 or more years.

Surface-water-quality data were collected at 18 sites. Water samples were analyzed for specific conductance, $\mathrm{pH}$, alkalinity, dissolved sulfate, total-recoverable and dissolved iron and manganese, dissolved solids, and other properties and constituents. Dissolved-solids concentrations can be estimated from specific conductance measurements using the equation $0.68 \mathrm{~K}=\mathrm{S}$. Specific conductance values ranged from 120 to 2,200 microsiemens per centimeter at 25 degrees Celsius. Values of $\mathrm{pH}$ for area streams were common to natural waters. Average concentrations of total recoverable iron ranged from 830 to 15,000 micrograms per liter and of total recoverable manganese, from 170 to 1,100 micrograms per liter. These concentrations commonly exceeded the U.S. Environmental Protection Agency's criteria for domestic use of 300 and 50 micrograms per liter for iron and manganese, respectively. Sulfate exceeded the criteria of 250 milligrams per liter for domestic water supplies at one site. Average alkalinity concentration was 137 milligrams per liter which is adequate to buffer small acid influxes. Suspended-sediment yields ranged from less than 50 to more than 300 tons per square mile per year.

Unconsolidated aquifers located in bedrock valleys yield 20 to 500 gallons per minute of ground water; bedrock aquifers in the area usually yield less than 10 gallons per minute. Water in deep bedrock aquifers is highly mineralized. U.S. Environmental Protection Agency's criteria for public water supplies were not always met for iron, manganese, chloride, and sulfate in ground-water supplies in the area. 


\title{
1.0 INTRODUCTION
}

1.1 Objective

\section{AREA 31 REPORT TO AID PREPARATION OF MINING PERMITS}

\author{
Hydrologic information provided in this report partially meets the \\ needs set forth by the "Surface Mining Control and \\ Reclamation Act of 1977".
}

\begin{abstract}
A need for hydrologic information and analysis on a scale never before required nationally was created when the "Surface Mining Control and Reclamation Act of 1977 " was signed into law as Public Law 95-87 on August 3, 1977. This need is partially met by this report, which broadly characterizes the hydrology of Area 31 in the Eastern Region of the Interior Coal Province in southeastern Illinois and southwestern Indiana (fig. 1.1-1). This report is one of a series that covers the coal provinces nationwide. The report contains a brief text with an accompanying map, chart, graph, or other illustration for each of a number of water-resources-related topics that describe the hydrology of the area.
\end{abstract}

The hydrologic information presented here and available through sources identified in this report, may be used to describe the general hydrology of a proposed mine in Area 31. This hydrologic information, along with the lease applicant's sitespecific data and data from other sources, can provide a more detailed picture of the hydrology near the mine and the anticipated hydrologic consequences of the mining operation.

The information contained herein should be useful to surface-mine owners, mine operators, and consulting engineers in preparing permit applications, and to regulatory authorities in appraising the adequacy of the applications. 


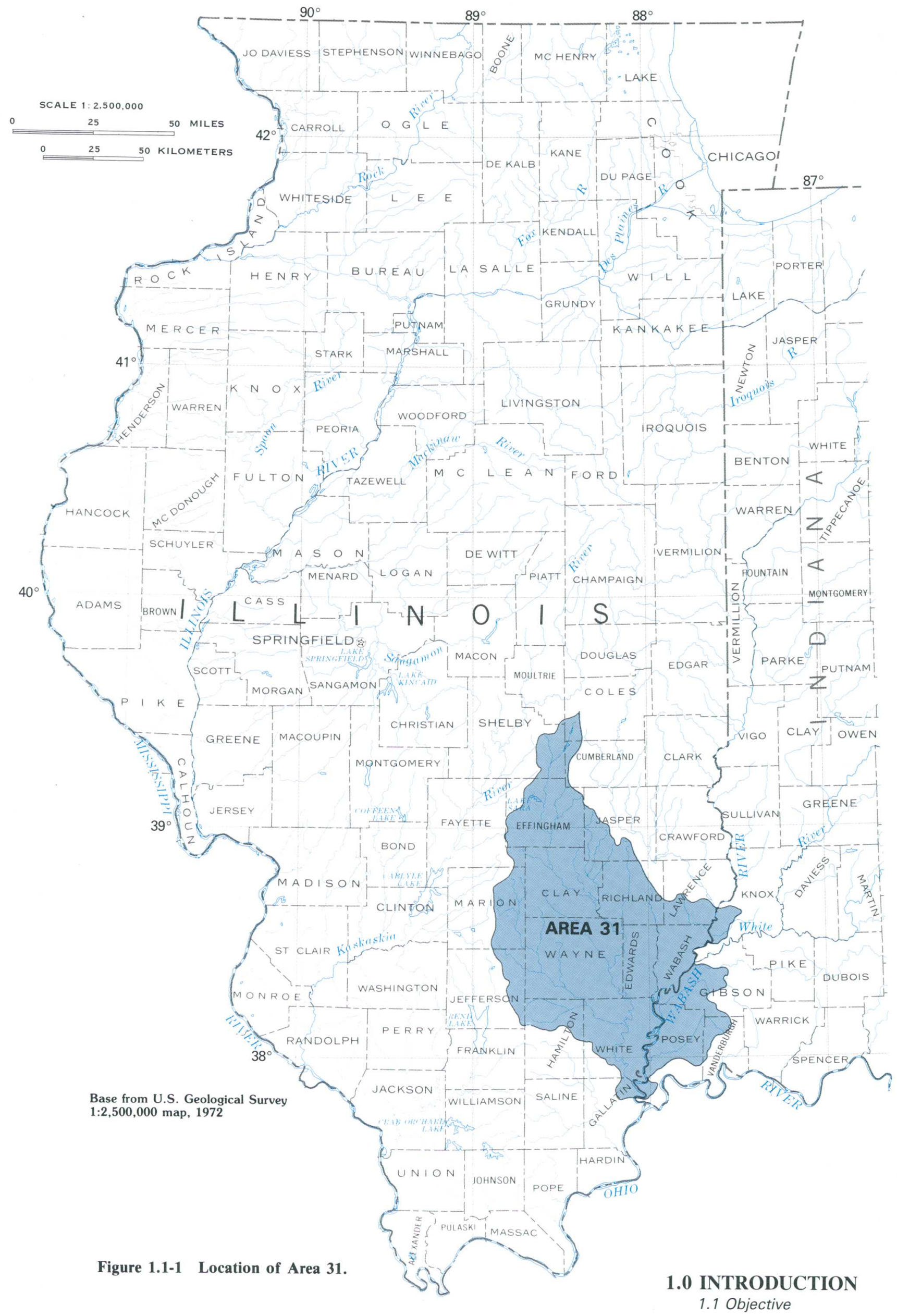




\title{
1.0 INTRODUCTION--Continued 1.2 Study Area
}

\section{AREA 31 IS LOCATED IN EASTERN REGION OF THE INTERIOR COAL PROVINCE}

\author{
Area 31 is located in southeastern Illinois and southwestern \\ Indiana and is primarily drained by the Little Wabash River. \\ It includes parts of three physiographic divisions.
}

Area 31 is located in the Eastern Region of the Interior Coal Province, commonly called the Eastern Interior Coal Field (Smith and Stall, 1975, 1977), and covers about 4,500 square miles in southeastern Illinois and southwestern Indiana (fig. 1.2-1). The area includes all or part of three drainage basins, or cataloging units, as delineated by the Office of Water Data Coordination on State Hydrologic Unit Maps (U.S. Geological Survey, 1975). Each unit is identified by an 8-digit number. The hydrologic units included in Area 31 are the lower Wabash River (05120113), Little Wabash River (05120114), and Skillet Fork (05120115) (fig. 1.2-2). The Little Wabash River, including its tributary Skillet Fork, drains over 70 percent of the area.

The study area includes all of Clay, Edwards, Wabash, and Wayne Counties and parts of Coles, Cumberland, Effingham, Gallatin, Hamilton, Jasper, Jefferson, Lawrence, Marion, Moultrie, Richland, Shelby, and White Counties in Illinois and Gibson, Knox, Posey, and Vanderburgh Counties in Indiana. The population of the study area is about 201,000 (1980 census, Edgar, 1982, p. 530-569). Cities with populations of 5,000 or more in the study area are Carmi, Effingham, Fairfield, Flora, Mattoon, Mount Carmel, and Olney, Illinois, and Princeton, Indiana. Mattoon, with a population of 19,055 in 1980, is the most populous city and is located on the boundary between Area 30 and Area 31.

The area includes parts of three physiographic divisions (fig. 1.2-3)-the Bloomington Ridged Plain, the Springfield Plain, and the Mount Vernon Hill Country (Willman and others, 1975, p. 16)-all of which are in the Till Plains Section of the Central Lowland Province. The Bloomington Ridged Plain is a series of broad morainic ridges that alternate with wide areas of relatively flat to gently undulating till plains. The Springfield Plain is level to gently undulating and the Mount Vernon Hill Country is flat to gently rolling with broad alluvial valleys along the major streams (Thornburn, 1963). 


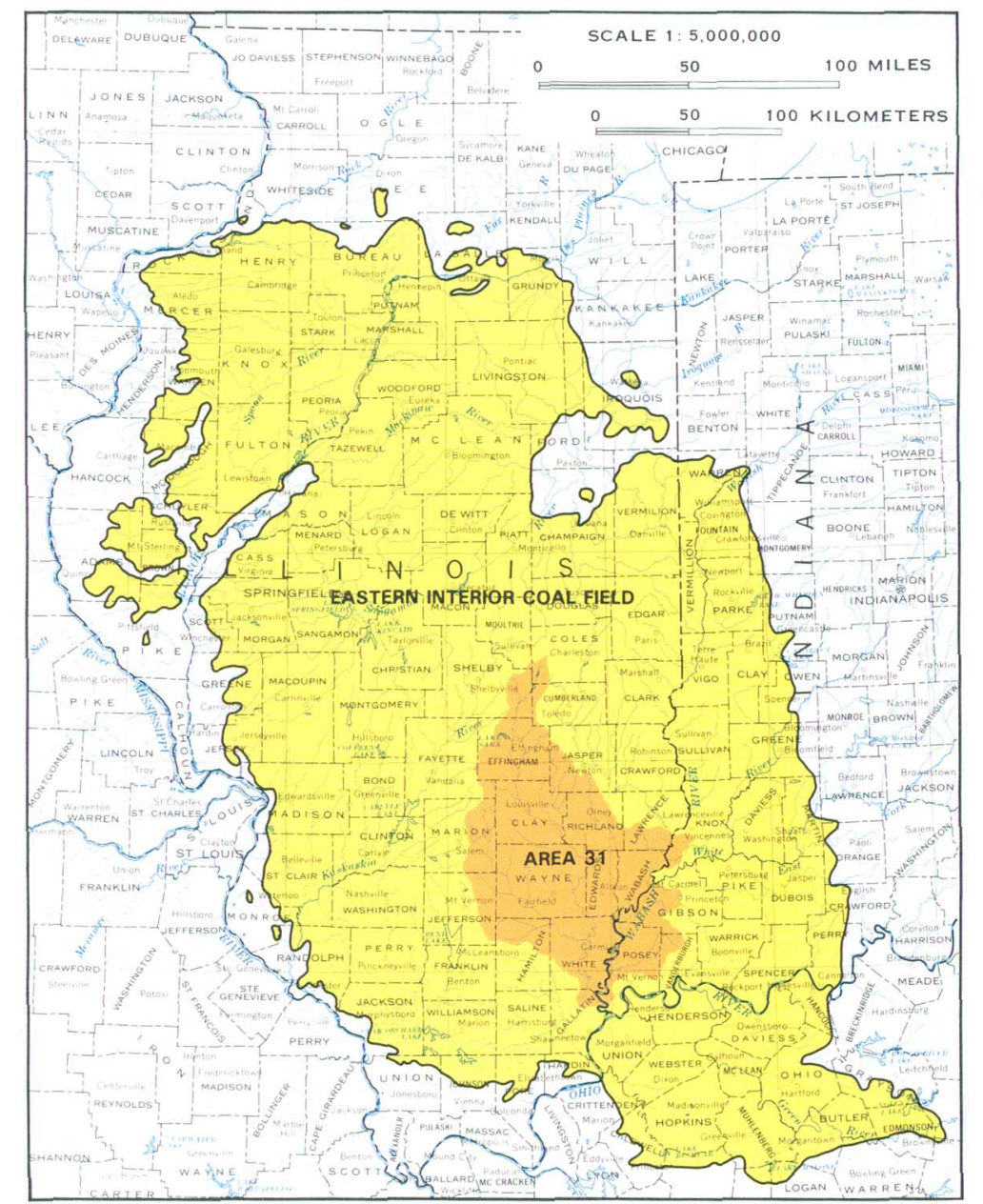

Figure 1.2-1 Location of the study area
in the Eastern Interior Coal field.

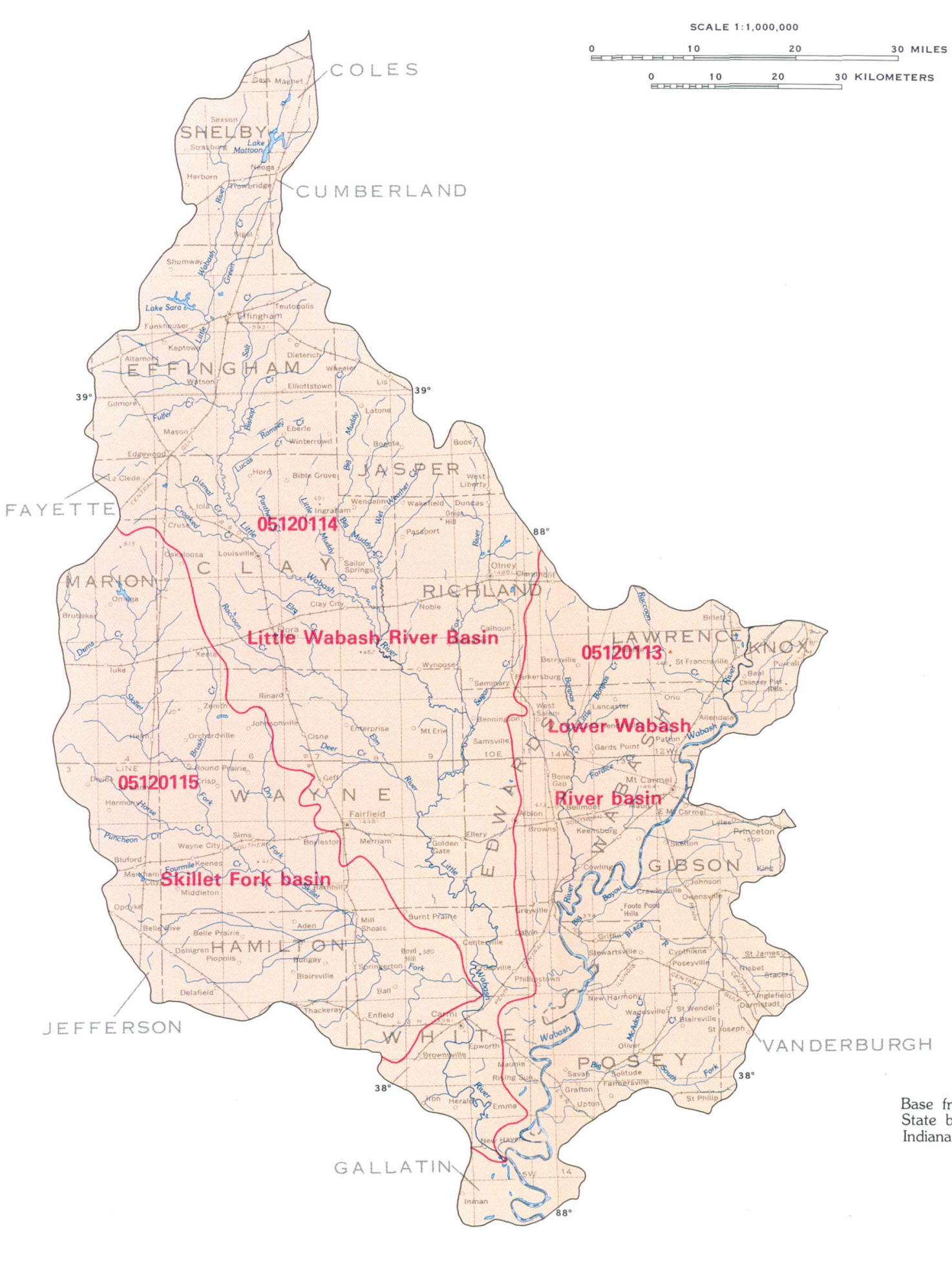

Figure 1.2-2 Hydrologic units.

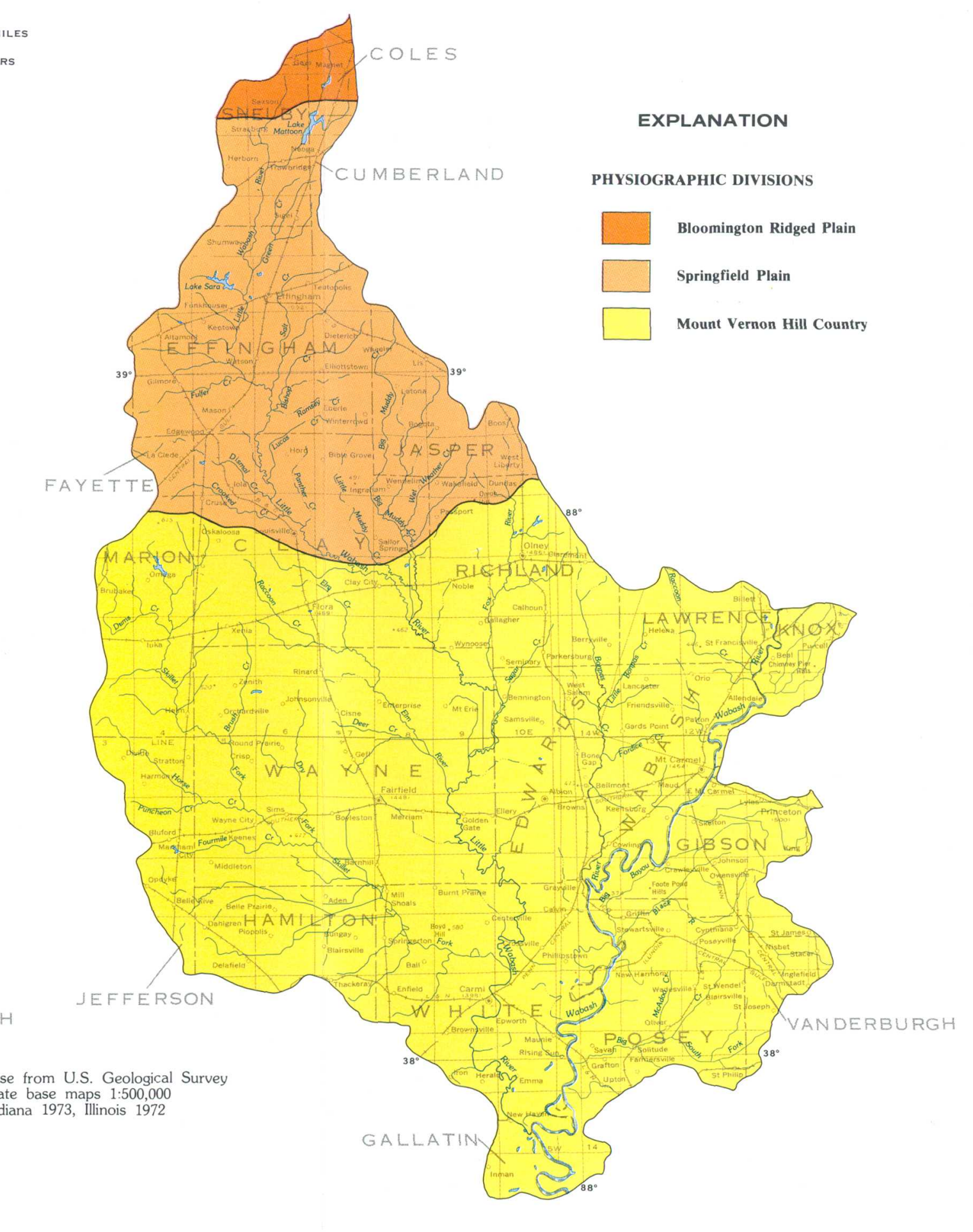

Figure 1.2-3 Physiographic divisions. 


\title{
2.0 COAL-MINING POTENTIAL AND HISTORY
}

\section{AREA 31 IS RICH IN ENERGY RESOURCES}

\author{
All of Area 31 is underlain by coal. Oil \\ and gas are produced in every county.
}

All of Area 31 is underlain by coal. Identifiable coal reserves, as of January 1976, totaled about 27.5 billion tons. About 0.8 percent of these reserves could be extracted by surface mining (Smith and Stall, 1975, second printing 1977). The only active coal mine in Area 31 is an underground mine located near Keensburg in Wabash County, Illinois. This mine produced $2,509,918$ tons of coal in 1982 , which was 4.1 percent of the total coal produced in Illinois and 7.0 percent of the coal produced from underground mines in Illinois (Illinois Department of Mines and Minerals, 1983).

Mining laws, coal seam thickness and accessibility, and quality of the coal deposits determine the development potential (fig. 2.0-1). The Illinois State Geological Survey classified the development potential as high (active mines or equivalent conditions), moderate (coal in thinner and deeper seams), and low (coal that will not be mined in the forseeable future) (Treworgy and Bargh, 1982, p.2).

Oil and gas are produced in every area county. In Illinois, the area produced 82 percent of the State's total crude oil; 21,792,755 barrels in 1979 (Van Den Berg and Elyn, 1981, p. 7). Coles and Wayne Counties, in Illinois, produced 706 million cubic feet of natural gas in 1979 , which was 44.5 percent of the total State production. Production figures for Indiana are not available at this time.

Rickert and others (1979) suggest that the coal resources of the Eastern Interior Coal Field are among those most likely to be used for synthetic fuel production because of the large amount of coal available, plentiful water supplies, lack of serious geologic constraints, and proximity to northeastern markets. The Nation's move toward energy independence and diminishing domestic supplies of oil and gas could also increase the demand for midwestern coal.

The first coal discovery in North America was by Marquette and Joliet in 1673 along the Illinois River. The first commercial underground coal mine in Illinois was opened in 1810 in Jackson County (Andros, 1915). Commercial surface mining began in 1866 near Danville, Illinois. Early surface mining was accomplished by removing overburden with horsedrawn scrapers. Coal was hauled out of the mine pit in wagons and wheelbarrows. Within two decades, the steam shovel, made mostly of wood, was used to remove up to 12 feet of overburden. From these beginnings, coal mining technology has progressed to the giant electricpowered shovels of today that remove up to 220 cubic yards of material in a single bite (Lewis, 1972).

Coal production in Area 31 from 1882 through 1982 was about 100 million tons. Peak production was reached during World War I. The Depression of the 1930's was accompanied by a decline in production that was reversed during World War II. Another decline in production occurred when diesel locomotives and alternative industrial fuels came into use. Increased energy consumption, declining oil and gas reserves, and new energy conservation methods have resulted in an increase and leveling off of production during the past two decades (Nawrot and others, 1980). 


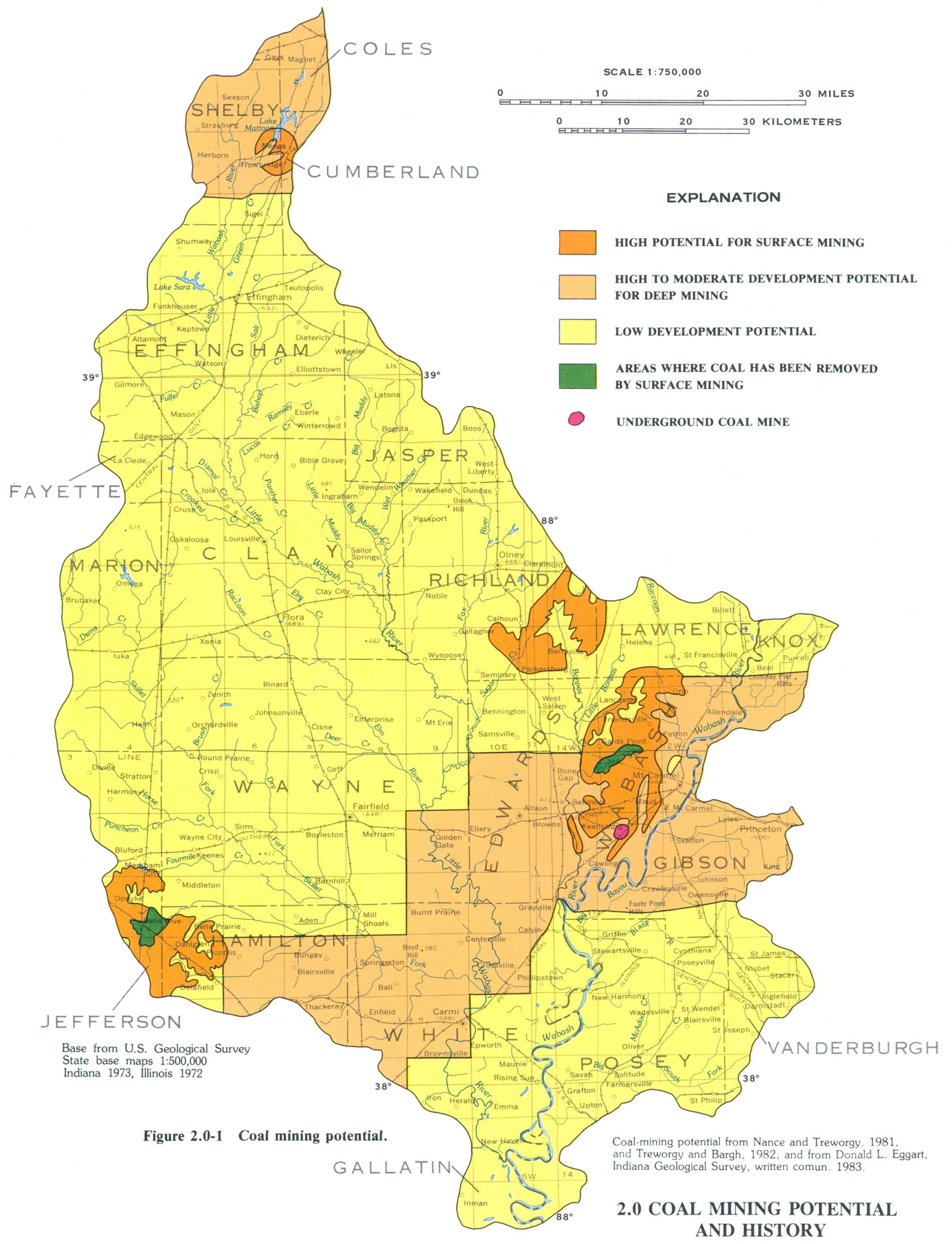




\subsection{GEOLOGY \\ 3.1 Surficial Geology}

\section{GLACIAL DEPOSITS COVER AREA}

Glacial deposits are parent material for area soils. Loess, lake sediments, and alluvium cover Area 31.

Glacial deposits of Pleistocene age overlie the bedrock, form the land surface, and are the parent material for most soils in Area 31 (fig. 3.1-1). They are important sources of building materials and ground water (Piskin and Bergstrom, 1975). The glacial deposits are less than 50 feet thick on the uplands and more than 100 feet thick in bedrock valleys under the Little Wabash River, Bonpas Creek, Skillet Fork, and Wabash River (Willman and others, 1975, p. 213 and 216; Piskin and Bergstrom, 1975; Gray and others, 1970).

The sands, gravels, and sandy till of the Illinoian Glasford Formation (fig. 3.1-2) covers almost all of the area except parts of Coles and Shelby Counties. There, the sandy till of the Wisconsinan Wedron Formation is present.

Peoria Loess, a wind-blown material, forms a mantle up to 15 feet thick on the land surface throughout the study area except in the river valleys. There, alluvium of the Cahokia and Martinsville Formations and the lake sediments of the Equality and Atherton Formations are present (Willman and others, 1975). 


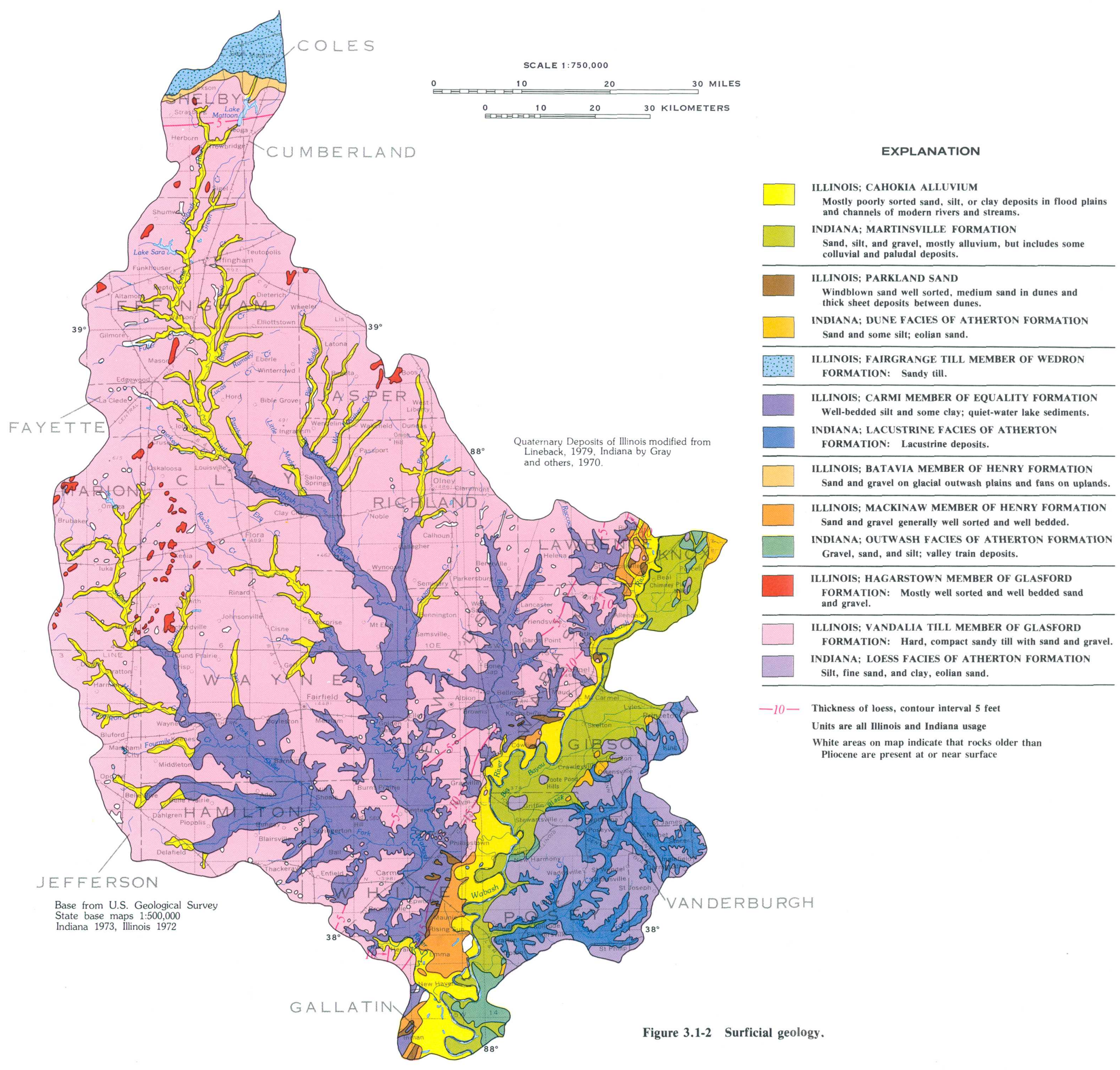

STRATIGRAPHIC CLASSIFICATION OF

THE PLEISTOCENE DEPOSITS OF ILINOIS

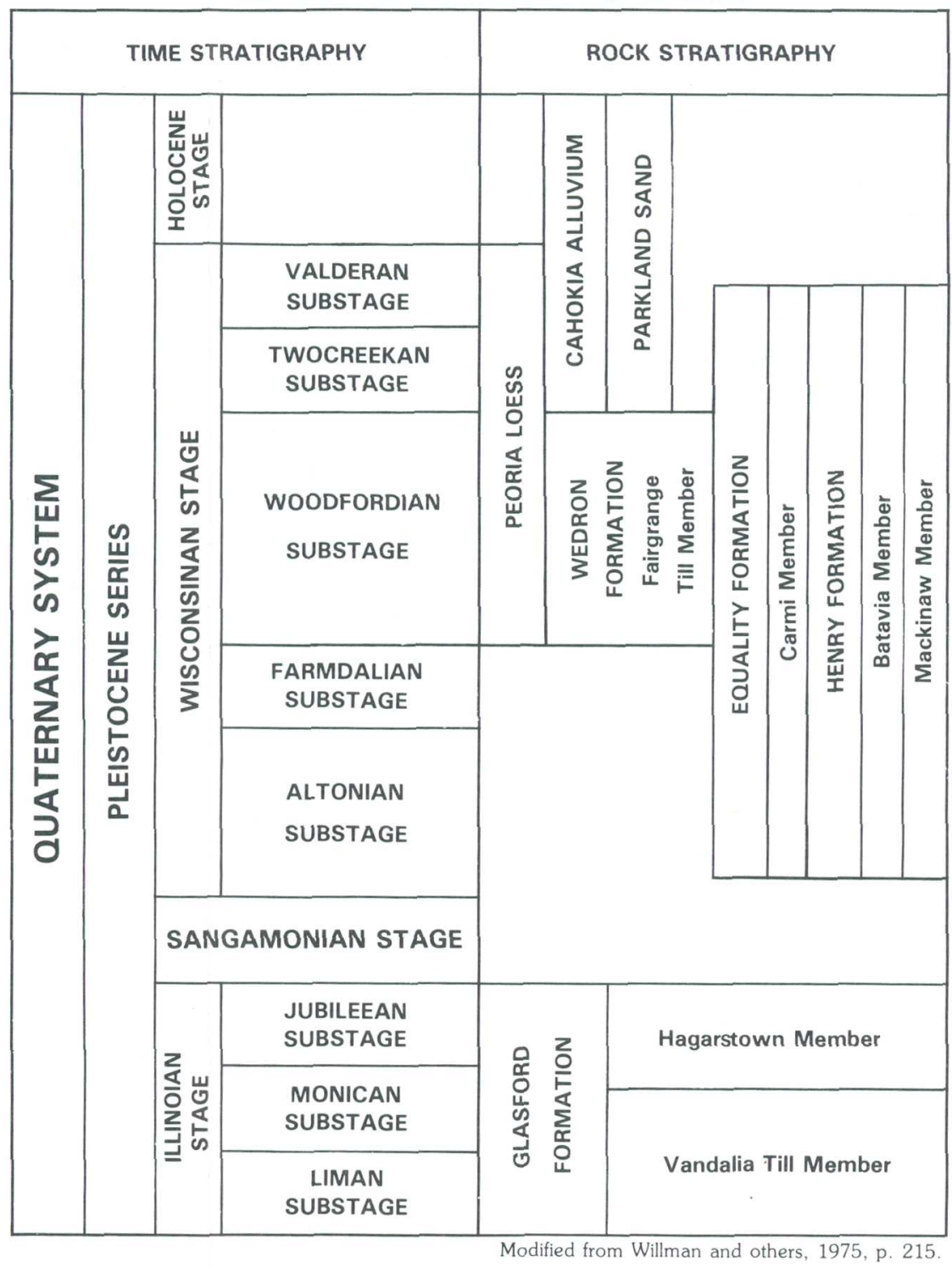

Figure 3.1-1 Stratigraphic column of Quaternary System showing location of rock units found in Area 31 the straigraphic nomenclature follows the usage of the usage of the U.S. Geological Survey). 


\title{
3.0 GEOLOGY--Continued \\ 3.2 Bedrock Geology
}

\section{THE COAL-BEARING PENNSYLVANIAN SYSTEM IS THE UPPERMOST BEDROCK}

\begin{abstract}
Coal is interbedded with sandstone, siltstone, limestone, shale, and clay. Coal comprises no more than 2 percent of the Pennsylvanian System.
\end{abstract}

The Pennsylvanian System is the uppermost bedrock in Area 31 (fig. 3.2-1). The maximum depth of the Pennsylvanian System in Area 31 is about 2,500 feet (fig. 3.2-2) in White County, Illinois; this coincides with the deepest part of the Illinois basin-"a spoon-shaped structure" (Willman and others, 1975, p. 23) that is oriented north-northwest to south-southeast. The basin was formed by slow subsidence from Cambrian to post-Pennsylvanian times (Willman and others, 1975). This subsidence is the cause of the relative great depths of major coal seams in the area.

The Pennsylvanian System consists of sandstone, siltstone, limestone, shale, clay, and coal (fig. 3.2-3). Changes in lithology are sharply defined which indicates that the depositional environment was changing abruptly. Organic growth and decay in freshwater swamps formed peat deposits that were buried and compressed to form coal.

In Illinois, about 60 percent of the lower section of the Pennsylvanian System is sandstone; the remainder is mostly siltstone and shale. About 25 percent of the middle and the upper sections is sandstone, 5 to 10 percent is limestone, and 65 to 70 percent is shale and clay. Coal comprises no more than 2 percent of the Pennsylvanian System and is most prominent in the middle section (Willman and others, 1975). The Harrisburg (No. 5) Coal Member of the Carbondale Formation, which is the only coal now mined in the area (Illinois Department of Mines and Minerals, 1983), is being removed from a depth of about 700 feet in Wabash County, Illinois. 


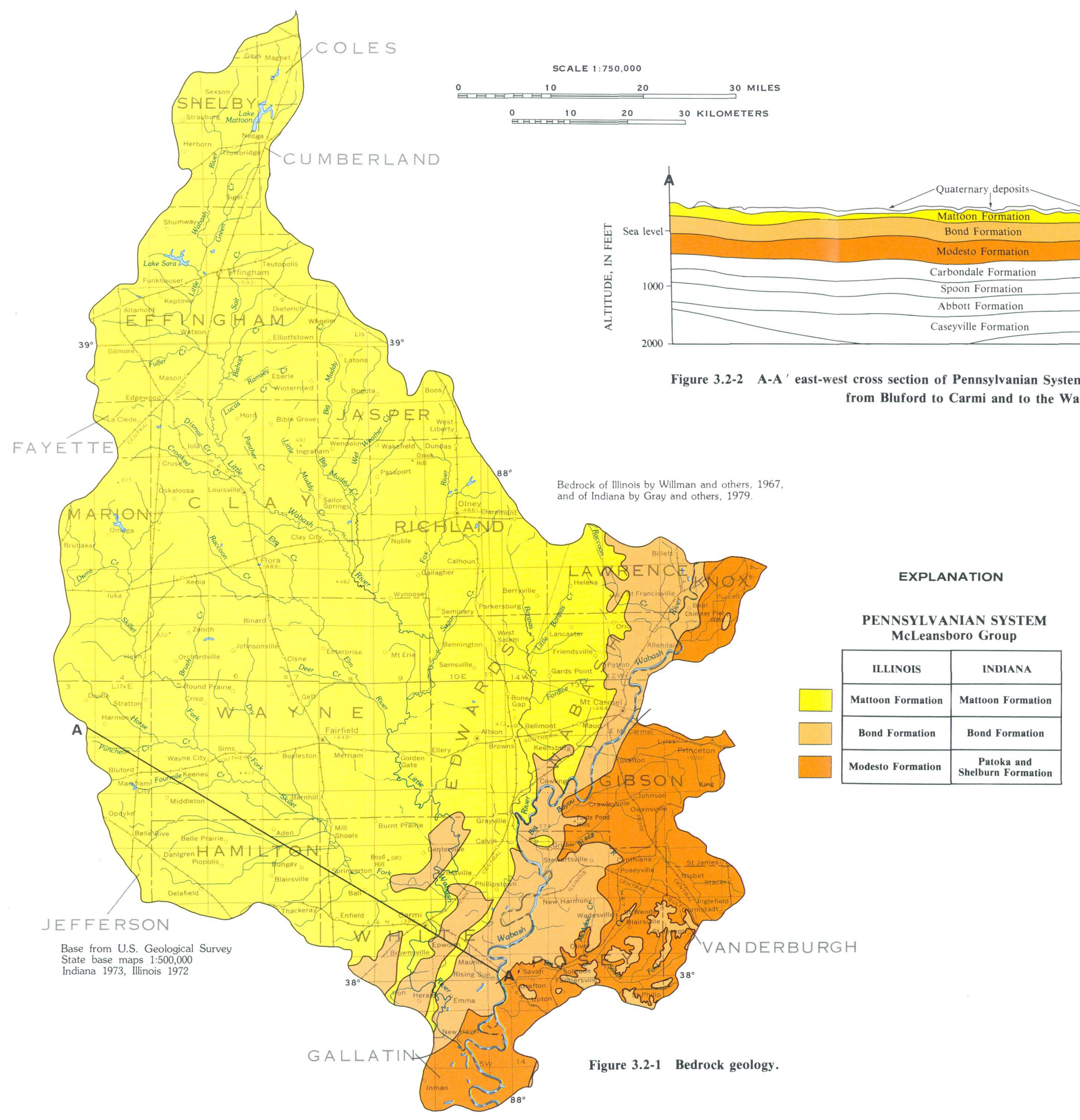

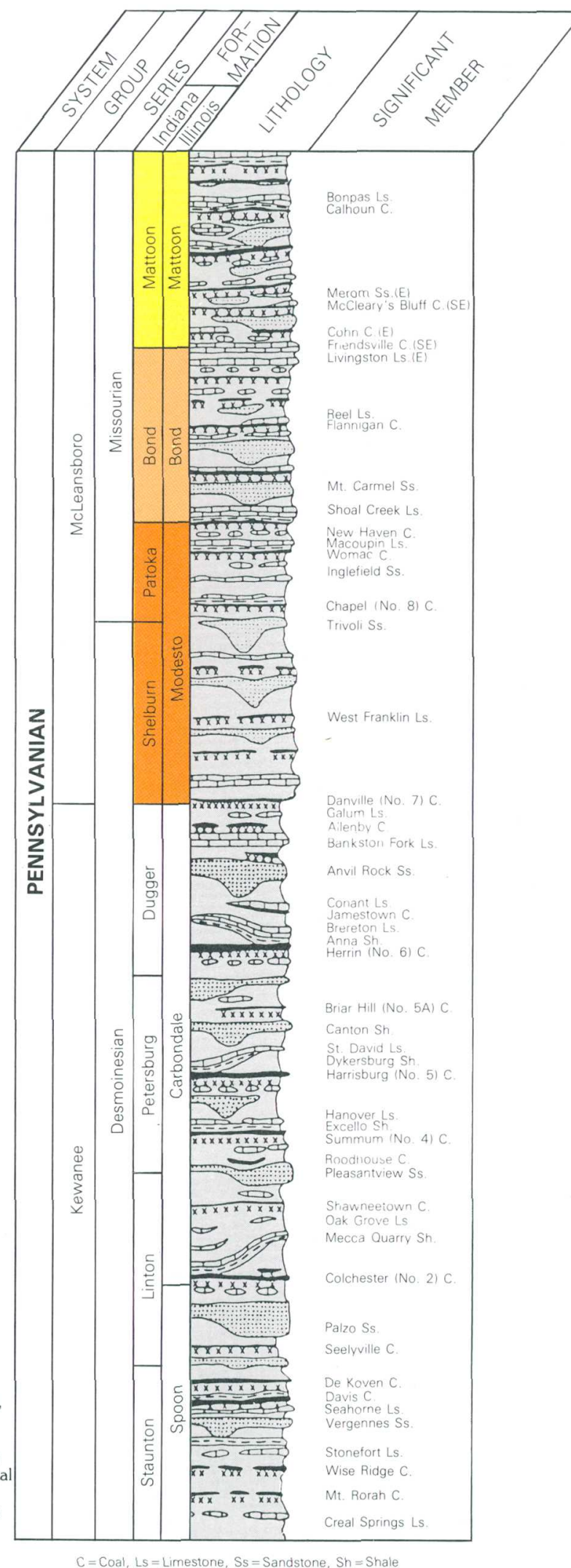

Figure 3.2-2 Stratigraphic section. 


\title{
4.0 SOILS
}

\section{SOILS ARE SLOWLY TO MODERATELY PERMEABLE ACIDIC, AND SUBJECT TO SLOPE EROSION}

\author{
Soils are slowly to moderately permeable, with good water-storage \\ capacity and are generally acidic with low to moderate productivity. \\ Area soils were developed from loess, glacial outwash, and alluvium. \\ Erosion is a problem on the loess soils.
}

Soil permeabilities in Area 31 range from 0 to 20 inches per hour, and $\mathrm{pH}$ ranges from 4.0 to 9.0. Most area soils have good water storage capacity ranging from 0.02 to 0.28 inch per inch and low to moderate crop productivity. General descriptions of each soil association are given in table 4.0-1. This information was obtained from soil surveys for individual counties (U.S. Department of Agriculture, 1977a, 1977b; Walker and Fehrenbacher, 1964; Fehrenbacher and others, 1967; Wallace and Fehrenbacher, 1969; and Holhubner and Fehrenbacher, 1972). The locations of soil associations are shown in figure 4.0-1.

Most area soils were developed from loess. Loess is a silty wind deposit that resulted from outwash material being blown from the valleys onto the uplands during glacial times. It was a friable, calcareous, medium-textured silt loam with high moisture storage capacity and contained many important plant nutrients that have been leached from the upper few feet of soil (Fehrenbacher and others, 1967). Presently, loess attains a thickness of up to 15 feet (Lineback, 1979). Loess is easily eroded unless cut in vertical slopes. Also, seepage may occur at the boundary with the underlying drift or bedrock in the area. The following soil associations were developed from Peoria Loess in Illinois: Sidell-Catlin-Flanagan-Drummer, OconeeCowden-Piasa, Hoyleton-Cisne-Huey, BirkbeckWard-Russell, Stookey-Alford-Muren, HosmerStoy-Weir, Ava-Bluford-Wynoose, and GrantsburgRobbs-Wellston. Loess soil associations in Indiana are Reesville-Ragsdale and Alford.
Other soil associations in the study area were developed from outwash and alluvial material. Outwash materials were deposited in the major river valleys by meltwater during the Illinoian glaciation. The composition of the outwash ranges from clay to gravel. Alluvial materials are located on the flood plains of major streams and are deposits occurring after the glacial period (Fehrenbacher and others, 1967). It consists mainly of poorly sorted silt, clay, and silty sand.

Information on the engineering properties of soils of Area 31 and detailed soil maps can be found in soil surveys for individual counties. These are published by the U.S. Department of Agriculture, Soil Conservation Service, in cooperation with the University of Illinois Agricultural Experiment Station, for Illinois counties and by the U.S. Department of Agriculture, Soil Conservation Service, in cooperation with Purdue University Agricultural Experiment Station, for Indiana counties.

Soil surveys and other information can be obtained from the State office of the Soil Conservation Service, $200 \mathrm{~W}$. Church Street, Champaign, Illinois 61820, for the Illinois counties and Soil Conservation Service, Corporate Square West, Suite 2200, 5610 Crawfordsville Road, Indianapolis, Indiana 46224, for the Indiana counties. A report by Wischmeier and Smith (1978) contains useful information on predicting rainfall erosion losses. 


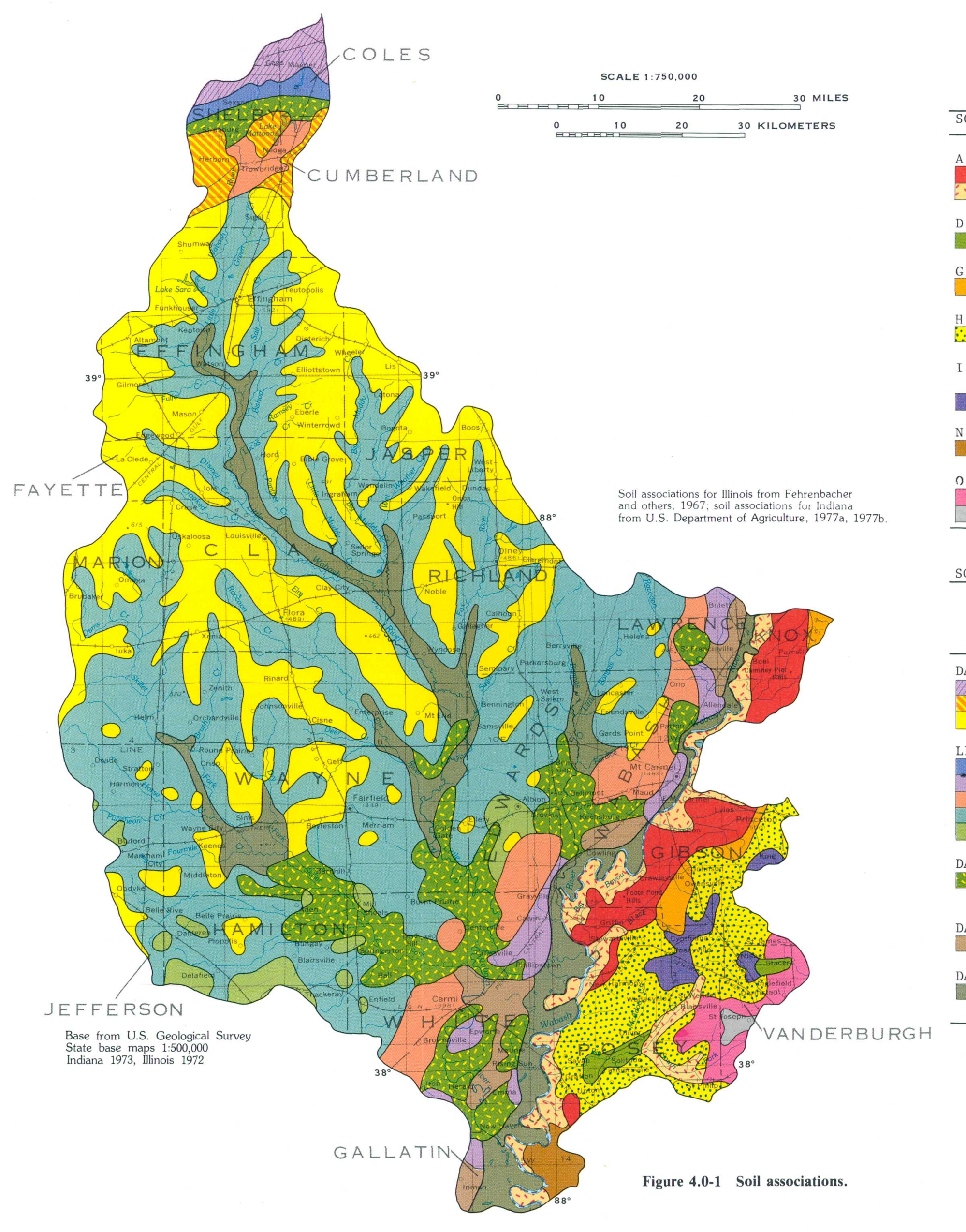

Table 4.0-1 Soil association characteristics in Area 31.

SOIL ASSOCIATIONS IN INDIANA

- NEARLY LEVEL, WEIL AND POORLY DRAINED, LOAMY SOILS ON FLOOD PLAINS

$\begin{array}{lll}\because & \text { A3 } & \text { Sloan - Ross - Vincennes - 2ipp } \\ \text { A4 } & \text { Stendal - Haymond - Wakeland - Nolin }\end{array}$

. NEARLY LEVEL, POORLY DRAINED, Clayey SOILS IN LACUSTRINe DEPOSitS

Patton - Lyles - Henshaw

SLOPING, WELL-DRAINED, LOAMY SOILS IN EOLIAN SAND DEPOSITS

i. H Alford

. NEARLY LeVEL, POORLY DRAINED, SILTY SOILS IN LOESS OR LOESS

AND GLACIAL TILL
I4 Reesville - Ragsdale

NEARLY LEVEL, POORLY DRAINED, SILTY SOILS WITH FRAGIPANS

N2 Weinbach - Wheeling

SLOPING, WELL-DRATNED, SILTY SOILS WITH FRAGIPANS

$\begin{array}{ll}01 & \text { Hosmer } \\ 02 & \text { Zanesville - wellston - Tilsit }\end{array}$

SOIL ASSOCIATIONS IN ILLINOIS

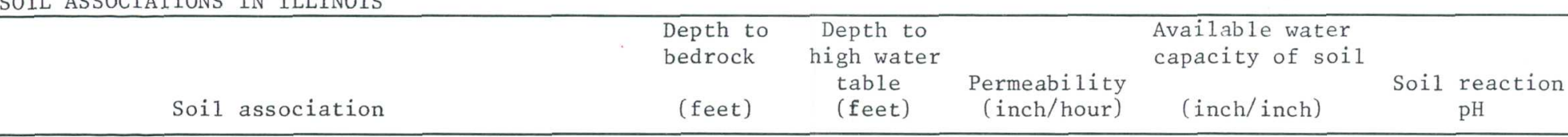

B

B
E Cocol1 - Catlin - Flanagan - Drummer
F Cowden - Piasa
Foyleton - Cisne - Huey

LIGHT-COLORED SOILS DEVELOPED PRIMARILY FROM LOESS

- M $\quad$ Birkbeck - Ward - Russe11

P Hosmer - Stoy - Weir

Ava - Bluford - Wynoose
Grantsburg - Robbs - Wellston

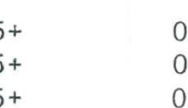

$0-6$
$0-3$
$0-3$

$0.20-2.00$

$\mathrm{pH}$

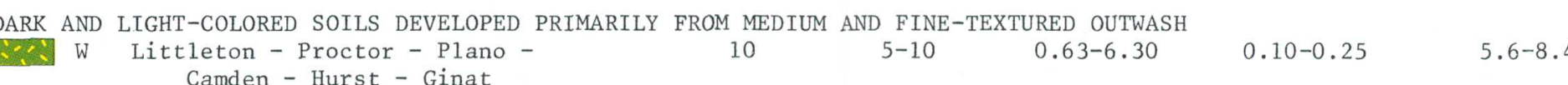
Camden - Hurst - Ginat

DARK AND LIGHT-COLORED SOILS DEVELOPED PRIMARILY FROM SANDY MATERIAL
$\mathrm{x}$ Hagener - Ridgeville - Bloomfield - Alvin 10

DARK AND LIGHT-COLORED SOILS DEVELOPED PRIMARILY FROM ALLUVIUM Lawson- - Beaucoup - Darwin -
Haymond - Belknap

$$
0-5-10 \quad 0-4
$$




\subsection{LAND USE}

\section{AGRICULTURE IS DOMINANT LAND USE}

\section{The major crops grown in the area are corn, soybeans, wheat, and hay. Oil and gas wells are located in every county.}

Area 31 covers 4,500 square miles, most of which is used for agriculture. The area consists of 67.0 percent cropland and 9.8 percent pasture (fig. 5.0-1). The main crops are corn, soybeans, wheat, and hay. The remainder of the land use is 14.4 percent woodland, 5.3 percent urban, 0.3 percent Federally-owned land not leased for crops, 0.4 percent water areas, and 2.8 percent other land use (Illinois Conservation Needs Committee, 1970; Kris Koth, Indiana State Planning Services Agency, oral commun., December 1982). Most woodland is classified as commercial forest; however, a small amount is used for recreation and conservation.

Seventeen lakes in the area cover a total area of 5,919 acres (Illinois Environmental Protection Agency, 1978). The lakes range in size from 20 to
1,750 acres and have maximum depths that range from 10 to 52 feet. The lakes are used for public water supply, recreation, wildlife, and flood control.

Other land uses are associated with fossil-fuel development. One coal mine is active in the areaan underground mine located in Wabash County where coal is removed from a depth of about 700 feet below the land surface. Oil and gas wells are located in every county; the highest concentration is in the central and southern parts of the area.

Land-use maps at a scale of $1: 250,000$ are available for most of Indiana through the Indiana State Board of Health, Stream Pollution Control Board (1980) and for Illinois from the U.S. Geological Survey. 


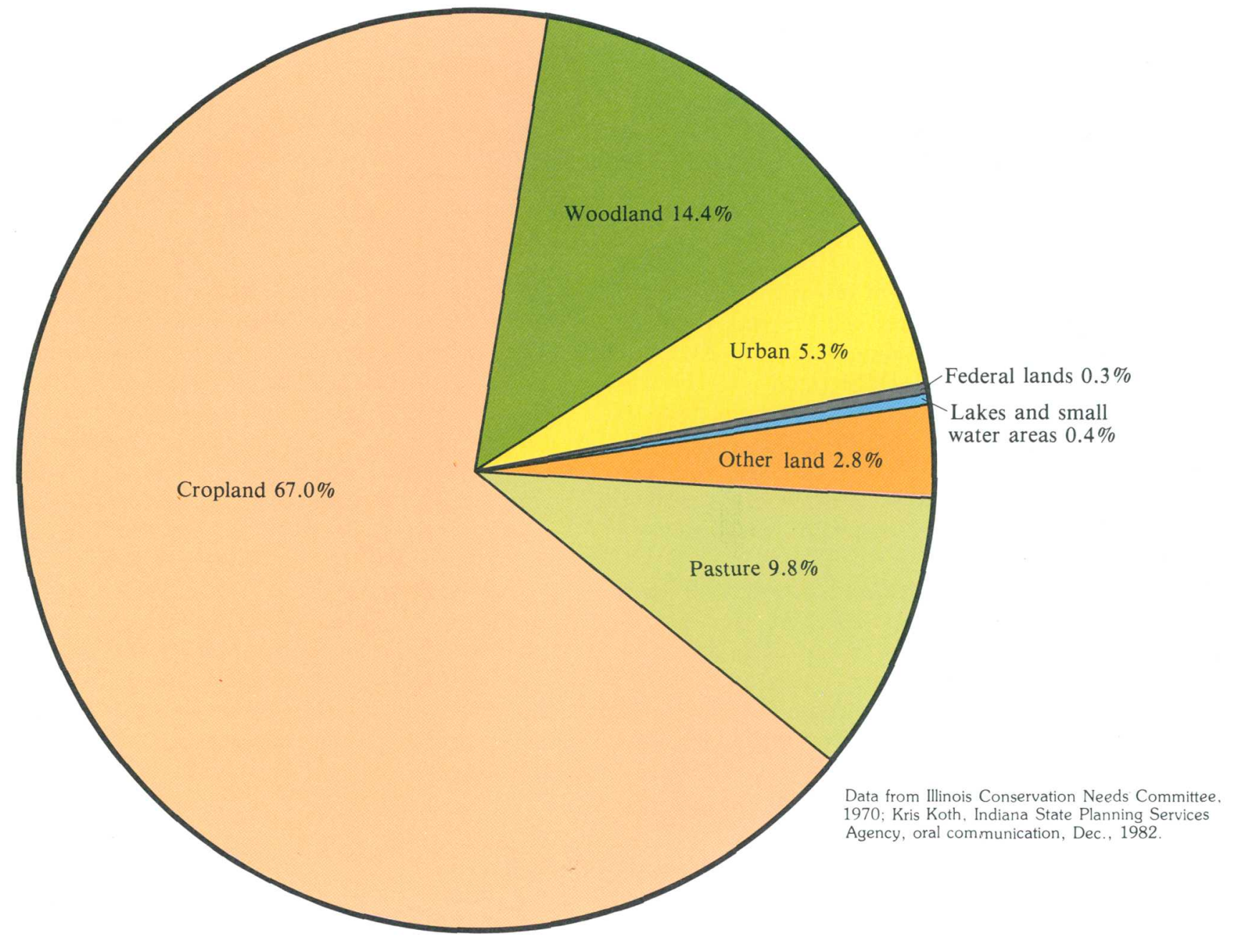

Figure 5.0-1 Land use in Area 31. 


\title{
6.0 WATER USE
}

\section{GROUND WATER SUPPLIED 56.3 PERCENT OF WATER USED}

\author{
Ground water and surface water supplied 66 million gallons per day in 1980 \\ for mining and mineral extraction, thermoelectric-power generation, \\ public water supplies, rural water supplies, manufacturing, and fish \\ and wildlife uses in Area 31.
}

Total water withdrawal in Area 31 from both surface- and ground-water sources was about 66 million gallons per day (Mgal/d) in 1980 (Kirk and others, 1982; Indiana Department of Natural Resources, 1982a and 1982b). Mining and mineral extraction and thermoelectric power generation were the largest water uses in the area followed by public water supplies, rural water supplies, manufacturing, and fish and wildlife (table 6.0-1).

Surface water supplied $28.9 \mathrm{Mgal} / \mathrm{d}$ or $43.7 \mathrm{per}$ cent of the water used (fig. 6.0-1). Thermoelectricpower generation accounted for $17.2 \mathrm{Mgal} / \mathrm{d}$ or about half of the surface water used in the area. Other surface water uses were public water supplies, $10.3 \mathrm{Mgal} / \mathrm{d}$, and mineral extraction, fish and wildlife, and manufacturing, less than $1.4 \mathrm{Mgal} / \mathrm{d}$ total.
Ground water supplied 37.2 Mgal/d or $56.3 \mathrm{per}$ cent of the water used. Mineral extraction, which is the largest water use in Area 31, accounts for $18.4 \mathrm{Mgal} / \mathrm{d}$ (fresh and brine water). Brine water is injected into the oil-producing formations to recover additional crude oil. Other ground-water uses were rural water use, $11.5 \mathrm{Mgal} / \mathrm{d}$; public water supply, $4.0 \mathrm{Mgal} / \mathrm{d}$; and manufacturing, 3.3 $\mathrm{Mgal} / \mathrm{d}$.

All rural-water use was assumed to be from ground water. Amounts of rural water use in Illinois are based on the population of people and livestock and on the area of irrigated land (Kirk and others, 1982, p. 7-9). Rural water-use data for Indiana is from the Indiana Department of Natural Resources, (1982b). 


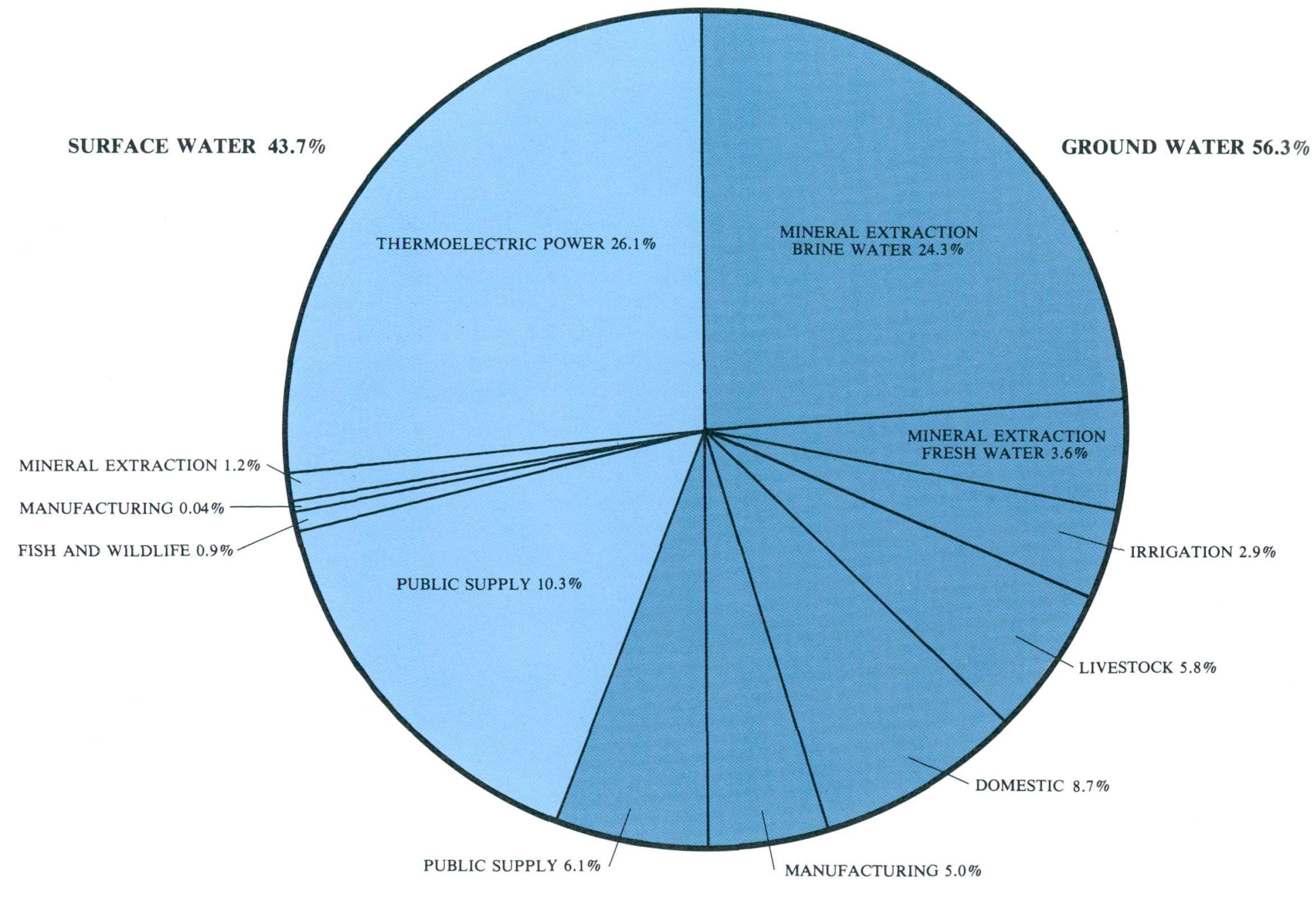

Figure 6.0-1 Water use in Area 31.
Table 6.0-1 Water use for 1980 in Area 31 in million

(Kirk and others, 1982; Indiana Department of Natural Resources,
1982a and 1982b.)

\begin{tabular}{|c|c|c|}
\hline \multicolumn{2}{|l|}{ Water use } & Daily rate \\
\hline & & \\
\hline Thermoelectric power & & 17.23 \\
\hline Public supply & & 10.26 \\
\hline Mineral extraction & & .768 \\
\hline Manufacturing & & .027 \\
\hline Fish and wildlife & & .566 \\
\hline Subtotal & & 28.85 \\
\hline GROUND WATER & & \\
\hline $\begin{array}{l}\text { Mineral extraction } \\
\text { brine water } \\
\text { fresh water }\end{array}$ & $\begin{array}{r}16.03 \\
2.35\end{array}$ & 18.38 \\
\hline Public supply & & 4.04 \\
\hline Manufacturing & & 3.29 \\
\hline $\begin{array}{c}\text { Rural water use } \\
\text { Domestic } \\
\text { Livestock } \\
\text { Irrigation }\end{array}$ & $\begin{array}{l}5.75 \\
3.81 \\
1.89\end{array}$ & 11.45 \\
\hline Sub tota1 & & 37.16 \\
\hline
\end{tabular}




\title{
7.0 PRECIPITATION
}

\section{THUNDERSTORMS PRODUCE HALF OF PRECIPITATION}

\author{
Average annual precipitation ranges from 39 to 44 inches as \\ rain, sleet, and snow. Two thirds of the precipitation \\ falls from April through September.
}

The average annual precipitation in Area 31 ranges from 39 inches in the north to 44 inches in the south (fig. 7.0-1). Annual precipitation during the wettest years has been as much as 69 inches and, in the driest years, has been less than 24 inches (Dawes and Terstriep, 1966, p. 5).

About two-thirds of the annual precipitation falls from April through September when cold fronts produce many thunderstorms. May has the highest average monthly precipitation. From October to March, precipitation averages about 17 inches over the area, about 8 to 12 percent of which is in the form of snow. The average annual snowfall ranges from 17 inches in the north to 14 inches in the south (fig. 7.0-2). Annual snowfall ranges from 2 to 43 inches (Dawes and Terstriep, 1966, p. 6).
The 24-hour precipitation statistically expected to be exceeded at a 2-year interval ranges from 3.1 inches in the northeast to 3.4 inches in the southwest (fig. 7.0-3) (Herschfield, 1961). Table 7.0-1 lists expected precipitation amounts for various rainfall durations and frequencies (Frederick and others, 1977; Hershfield, 1961).

U.S. Weather Bureau records are used to calculate the distribution of the mean annual precipitation. Daily precipitation data are published monthly by the National Oceanic and Atmosphere Administration (NOAA), National Climatic Center, Asheville, N. C. 


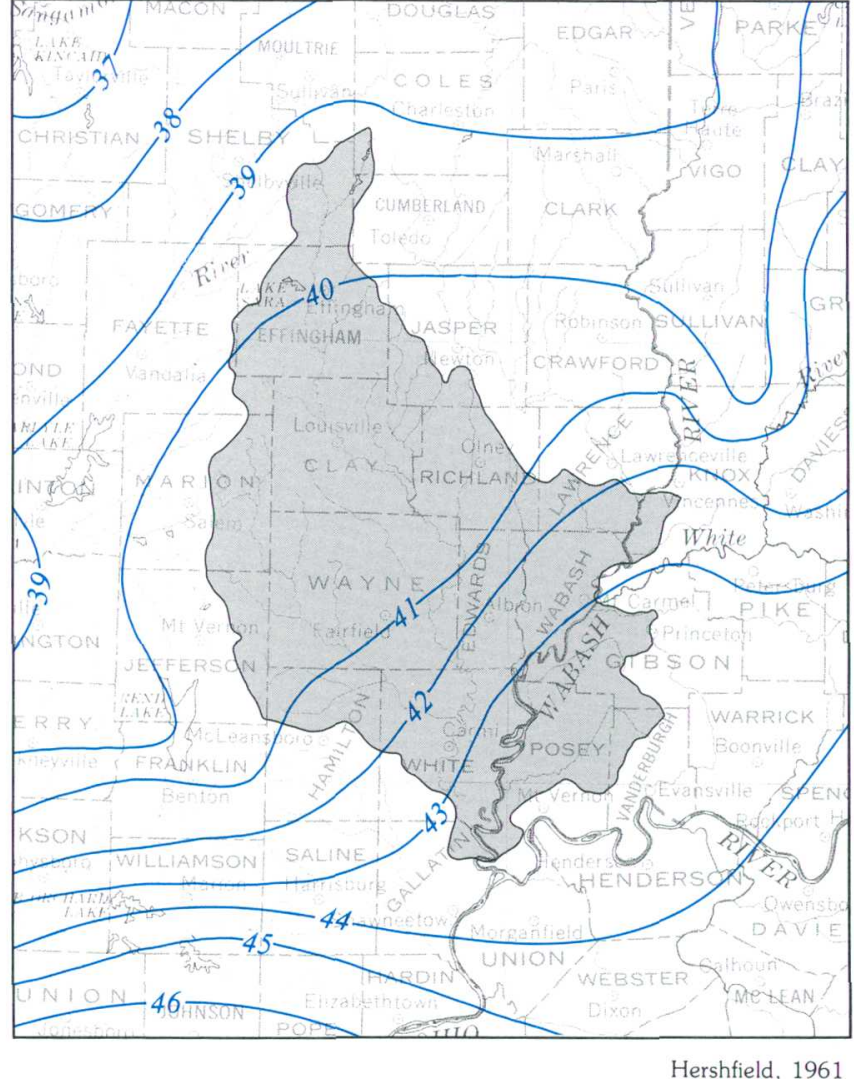

Figure 7.0-1 Average annual precipitation, in inches.

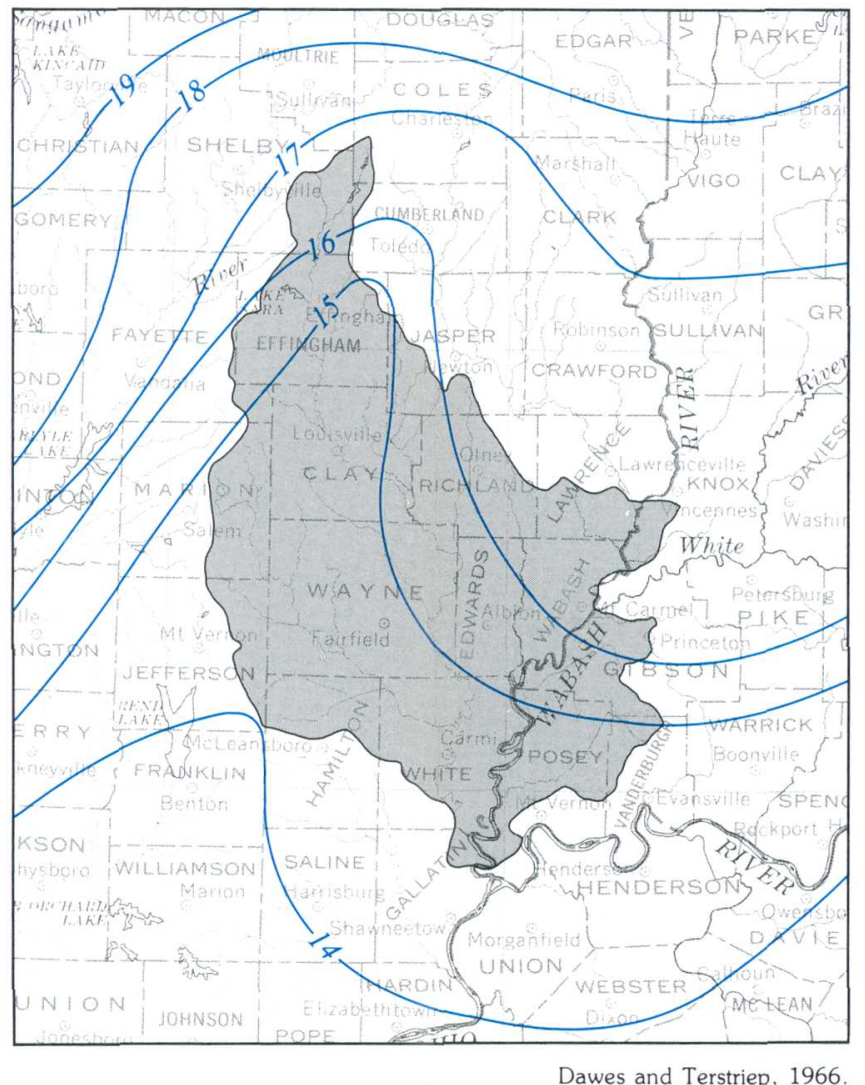

Figure 7.0-2 Average annual snowfall, in inches.

Table 7.0-1 Area 31 precipitation frequency values, in inches. (10-, 30-, and 60-minute values from Frederick and others, 1977:

\begin{tabular}{cccccc}
\multicolumn{5}{c}{$\begin{array}{c}\text { Frequency } \\
\text { (years) }\end{array}$} & \multicolumn{5}{c}{$\begin{array}{c}\text { Duration } \\
\text { (time) }\end{array}$} \\
\cline { 2 - 6 } & $10 \mathrm{~min}$ & $30 \mathrm{~min}$ & $60 \mathrm{~min}$ & $12 \mathrm{hr}$ & $24 \mathrm{hr}$ \\
\hline 2 & 0.7 & 1.2 & 1.5 & 2.9 & 3.2 \\
5 & 0.9 & 1.5 & 1.9 & 3.5 & 4.2 \\
10 & 1.0 & 1.7 & 2.2 & 4.0 & 4.6 \\
25 & 1.1 & 2.0 & 2.6 & 4.6 & 5.5 \\
50 & 1.2 & 2.2 & 2.9 & 5.0 & 6.0 \\
100 & 1.3 & 2.5 & 3.2 & 5.5 & 6.5 \\
\hline
\end{tabular}

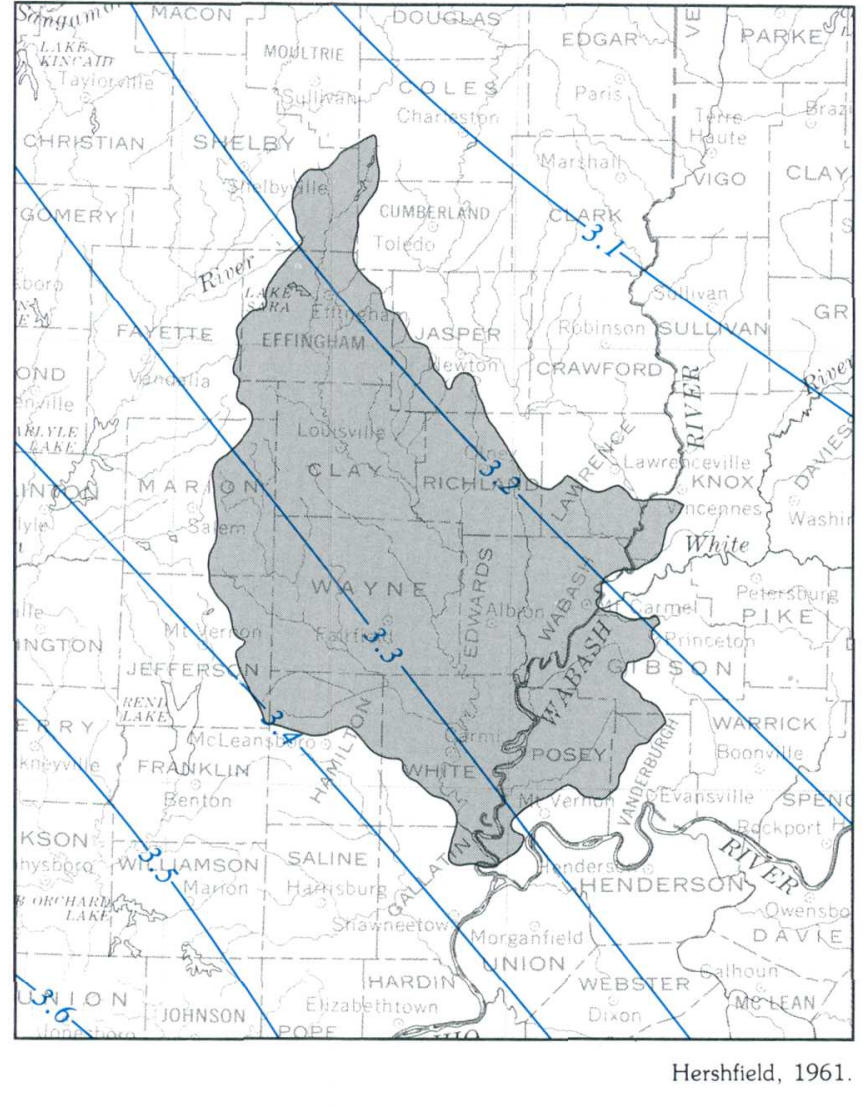

Figure 7.0-3 Two-year, 24-hour rainfall, in inches. 


\title{
8.0 HYDROLOGIC NETWORK
}

\section{SURFACE-WATER INFORMATION AVAILABLE FOR 33 SITES}

\author{
Area streams were monitored for discharge-high flow, peak \\ discharge, and low flow-and for water quality $-\mathrm{pH}$, \\ specific conductance, and concentrations of iron, \\ manganese, sulfur, and suspended sediment.
}

The location of 33 surface-water monitoring sites in Area 31 for which hydrologic information is available (table 8.0-1) are shown in figure 8.0-1. Streamflow data have been collected at 31 sites, including continuous-recording gages, partialrecord gages, and miscellaneous measurement sites. Specific conductance and $\mathrm{pH}$ values, and concentrations of alkalinity, sulfate, dissolved solids, iron, and manganese are available for 18 sites. Suspended-sediment data are available for 11 sites. Site number 5 (Wabash River at New Harmony, Ill.) is the only site that is downstream from any mining activity. The site is 37.5 miles downstream from the mouth of Coffee Creek which drains the area where the one underground mine in Area 31 is located. Hydrologic data for area sites were published annually in the U.S. Geological Survey Water-Data Reports for Illinois and Indiana.
Streamflow data can be used statistically to define regional discharge, high flow, and peak discharges. Flow duration was determined for area continuous-record gages which indicated uniformity during periods of high flow, but nonuniformity during periods of low flow.

Statistical analysis of water-quality data shows a relation that is typical of natural waters exists between specific conductance and dissolved solids. Area waters are neutral to slightly basic and have a moderate dissolved sulfate content. However, the iron and manganese content of area streams is high. Suspended-sediment yields at site number 11, a daily record site, ranged from 178 to 420 tons per square mile per year during the 4-year period of record. 


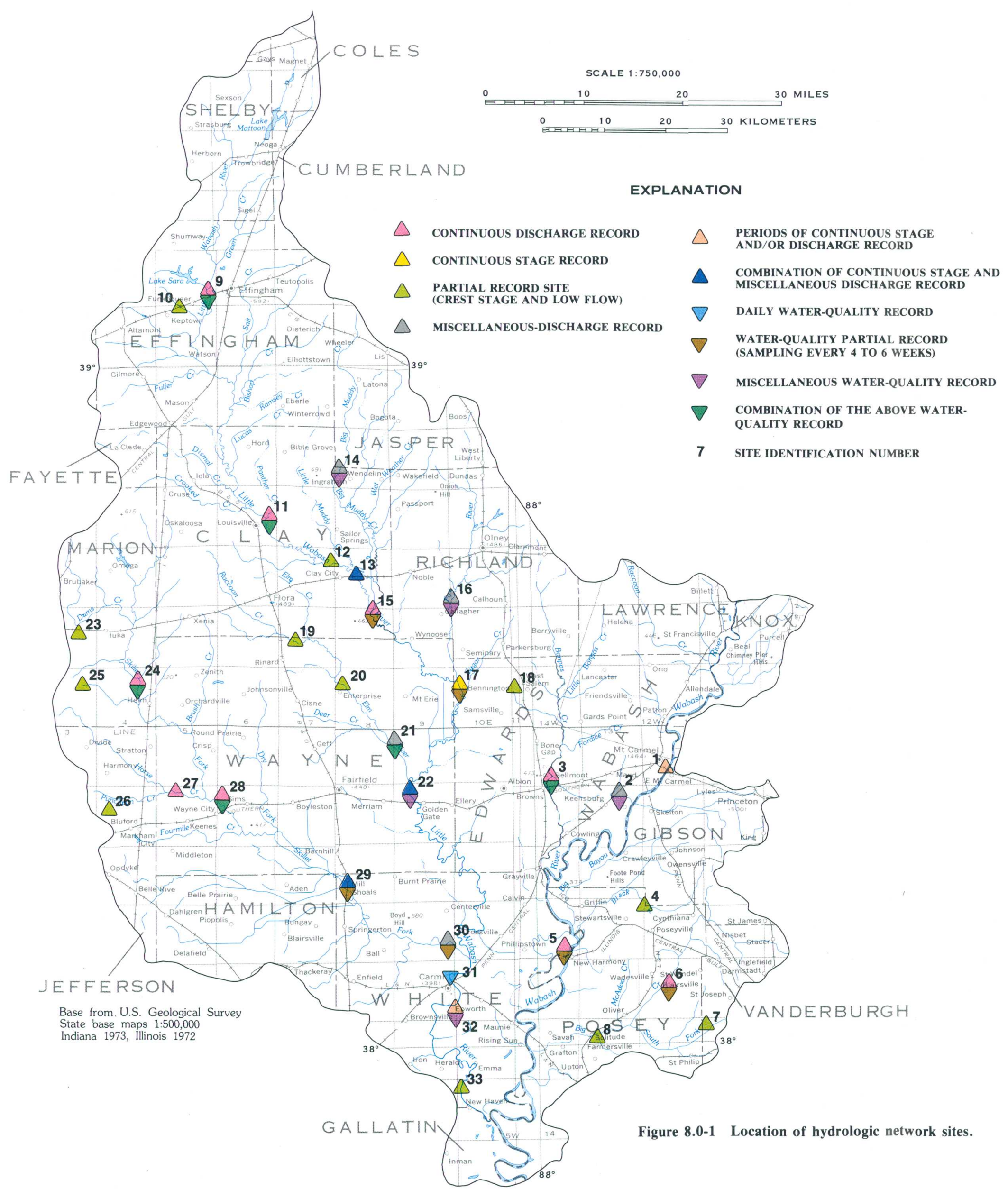

Table 8.0-1 Availability of hydrologic data in Area 31.

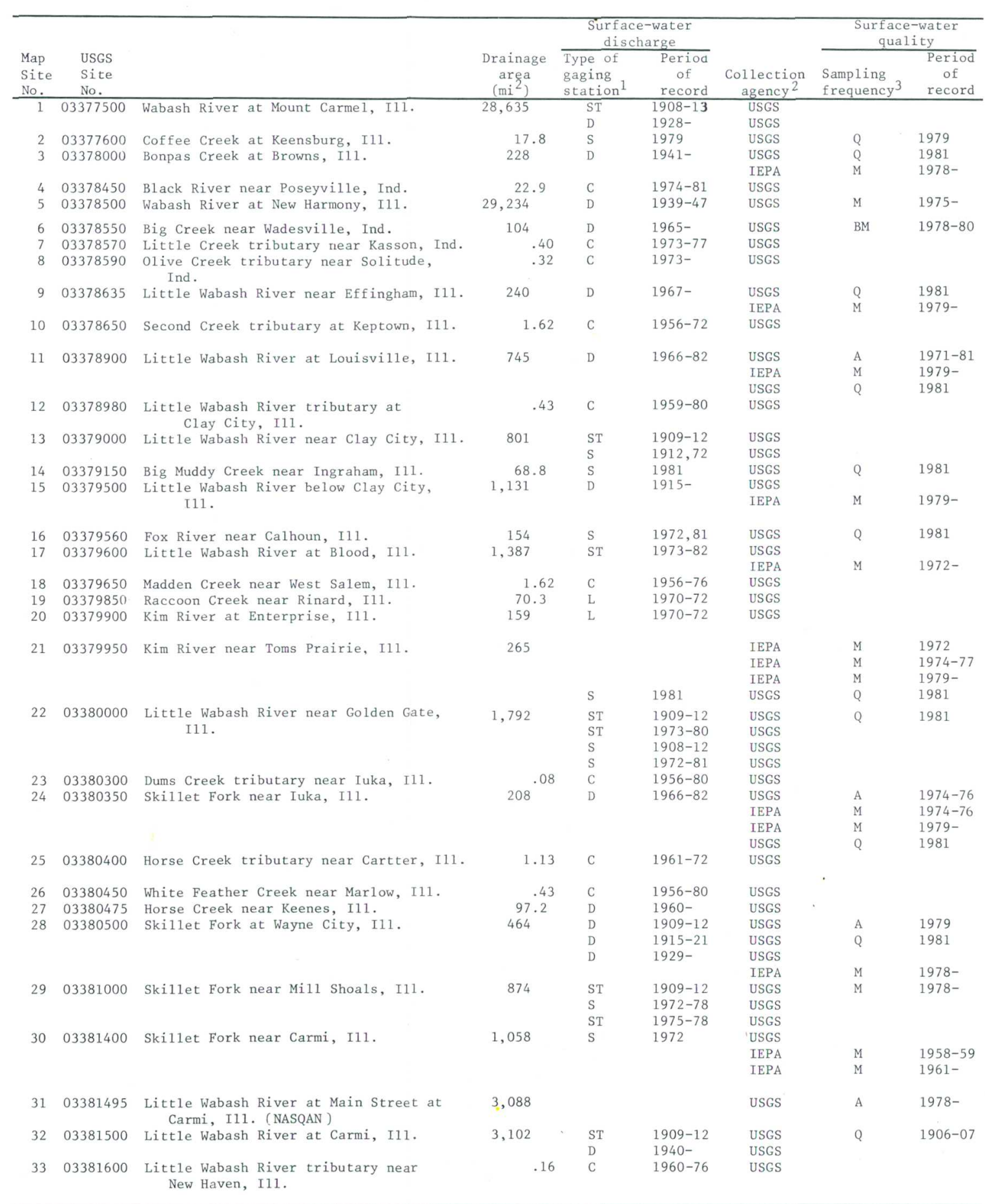

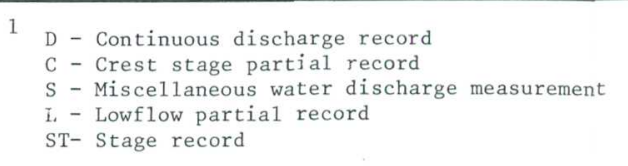

USCS - U.S. Geological Survey
IEPA - I11inois Environmental Protection Agency

M - Monthly water-quality sampling
$Q-$ Snnopticic water-quality sampling
A - Daily water-quality record 


\title{
9.0 SURFACE-WATER QUANTITY \\ 9.1 Average Discharge
}

\section{AVERAGE DISCHARGES COMPUTED FOR AREA STREAMS}

\author{
The relation of average stream discharge to drainage area \\ at 10 gaged sites in Area 31 can be used to estimate \\ average stream discharge at ungaged sites.
}

Average stream discharges were determined from the daily discharge records. Average discharges ranged from 90.5 to 27,350 cubic feet per second $\left(\mathrm{ft}^{3} / \mathrm{s}\right)$ for 10 gaging sites located in Area 31 (fig. 9.1-1) with drainage areas of from 97.2 to 28,635 square miles and for periods of record of 16 to 68 years (table 9.1-1).

The average discharge of ungaged stream sites can be estimated from the drainage area with the equation:

$$
Q_{a}=0.93 A^{0.99}
$$

where the average discharge $\left(Q_{a}\right)$ is in cubic feet per second, and the drainage area $(A)$ is in square miles (fig. 9.1-2). This relation was derived using a regression analysis with data from 10 gaging sites. A correlation coefficient of 0.996 with a standard error of estimate of $0.053 \log$ units $(+13.0$ and -11.5 percent error) is associated with the estimating equation.

The average stream discharge may be influenced by drainage area, soil characteristics, mean annual precipitation, area of lakes and ponds, forest cover, elevation, stream length, and slope as described by Sieber (1970). However, drainage area is the most significant variable in Area 31. 


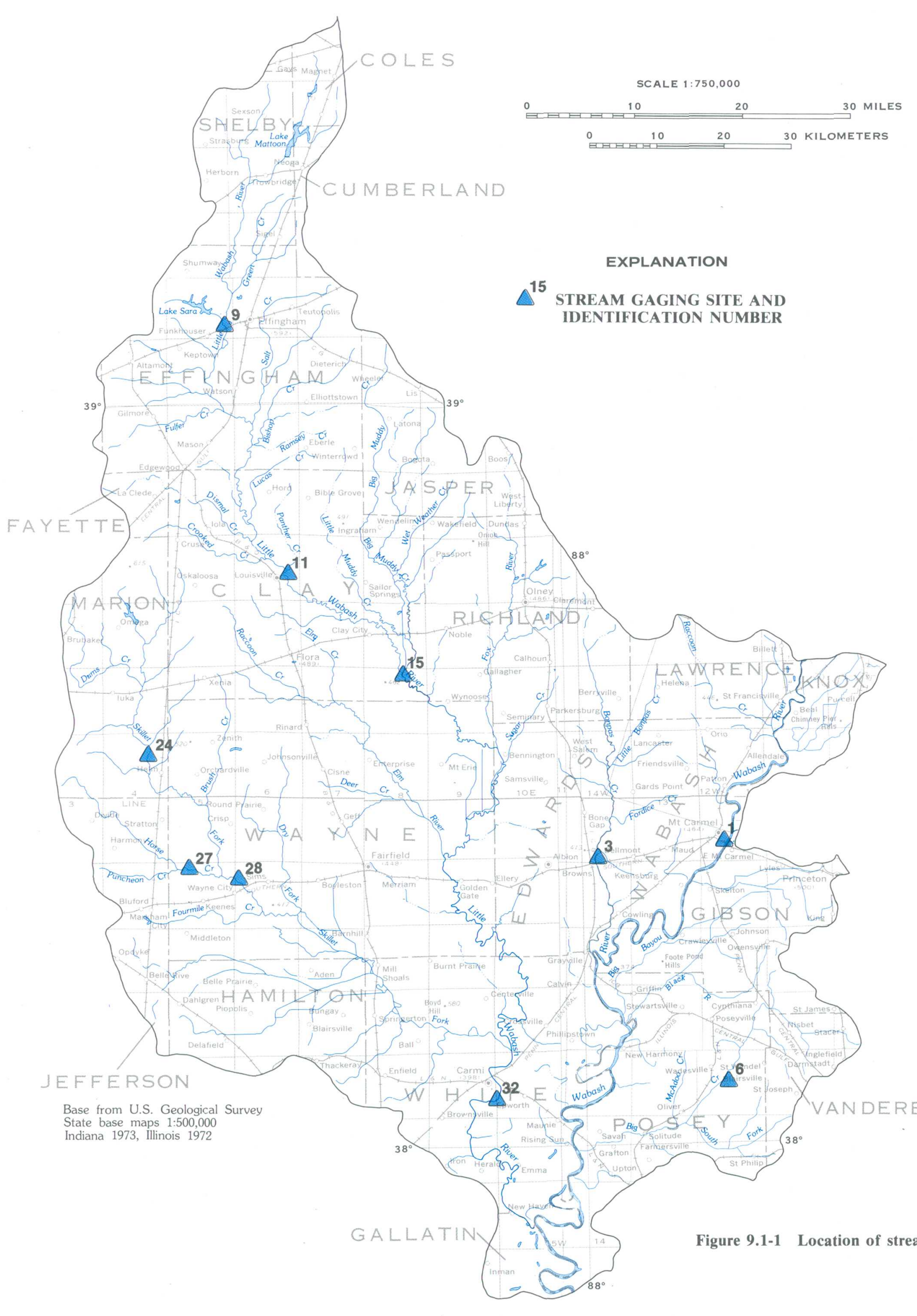

Table 9.1-1 Average discharge at streamflow gaging sites in Area 31.

\begin{tabular}{|c|c|c|c|c|}
\hline $\begin{array}{l}\text { Map } \\
\text { site } \\
\text { number } \\
\end{array}$ & Site name & $\begin{array}{c}\text { Drainage } \\
\text { area } \\
\left(\mathrm{mi}^{2}\right) \\
\end{array}$ & $\begin{array}{c}\text { Average } \\
\text { discharge } \\
\left(\mathrm{ft}^{3} / \mathrm{s}\right)\end{array}$ & $\begin{array}{l}\text { No. of } \\
\text { years of } \\
\text { record }\end{array}$ \\
\hline 1 & Wabash River at Mount Carme1, Il & 28,635 & 27,350 & 55 \\
\hline 3 & Bonpas Creek at Browns, Ill. & 228 & 221 & 42 \\
\hline 6 & Big Creek near Wadesville, Ind. & 104 & 112 & 17 \\
\hline 9 & Little Wabash River near Effingham, Ill. & 240 & 186 & 16 \\
\hline 11 & Little Wabash River at Louisville, Ill. & 745 & 584 & 17 \\
\hline & Little Wabash River below Clay City, Ill. & 1,131 & 873 & 68 \\
\hline 24 & Skillet Fork near Iuka, Ill. & 208 & 170 & 17 \\
\hline 27 & Horse Creek near Keenes, I11. & 97.2 & 90.5 & 23 \\
\hline & Skillet Fork at Wayne City, Il & & 385 & 65 \\
\hline 32 & Little Wabash River at C & 3,102 & 2,477 & 43 \\
\hline
\end{tabular}



Figure 9.1-2 Relation between average discharge and drainage area in Area 31. 


\title{
9.0 SURFACE-WATER QUANTITY--Continued \\ 9.2 Low Flow
}

\section{LOW-FLOW VALUES COMPUTED FOR GAGED SITES}

\author{
The 7-day low-flow values for six recurrence intervals are \\ presented for 10 gaged sites. Sites with drainage areas \\ of less than 240 square miles had a 7-day low-flow of \\ zero for all recurrence intervals of 5 or more years.
}

Low flow at ungaged sites can be estimated by correlating it to the discharge of a nearby continuous-record site where low-flow frequency has been defined. The flow condition on which most water-quality standards are based is the 7-day, 10 -year low flow which, at 10 continuous-record sites, ranged from 0 to 2,310 cubic feet per second. The 7-day, 10-year low flow is computed from the annual 7-day low-flow values which are based on the climatic year (April 1 to March 31).

Using a log-Pearson Type III distribution analysis (Meeks, 1983, p. G-5), the 7-day, 2-, 5-, 10-, 20-, 50-, and 100-year low-flow values were computed (table 9.2-1) for 10 continuous-record sites (fig. 9.2-1). All sites with less than 240 square miles of drainage area had a 7-day low-flow of zero for all recurrence intervals of 5 or more years. Figure 9.2-2 shows the relation of the 7-day, 2- and 100-year low-flows to drainage area for sites in the area.

Low flow occurs after several days of no precipitation or snowmelt. Low flow in Area 31 is composed of ground-water inflow and industrial and municipal waste-disposal effluents. Lake Sara and Lake Mattoon-two large reservoirs located near the headwaters of the Little Wabash Rivermay influence low flows because of reservoir regulation. 


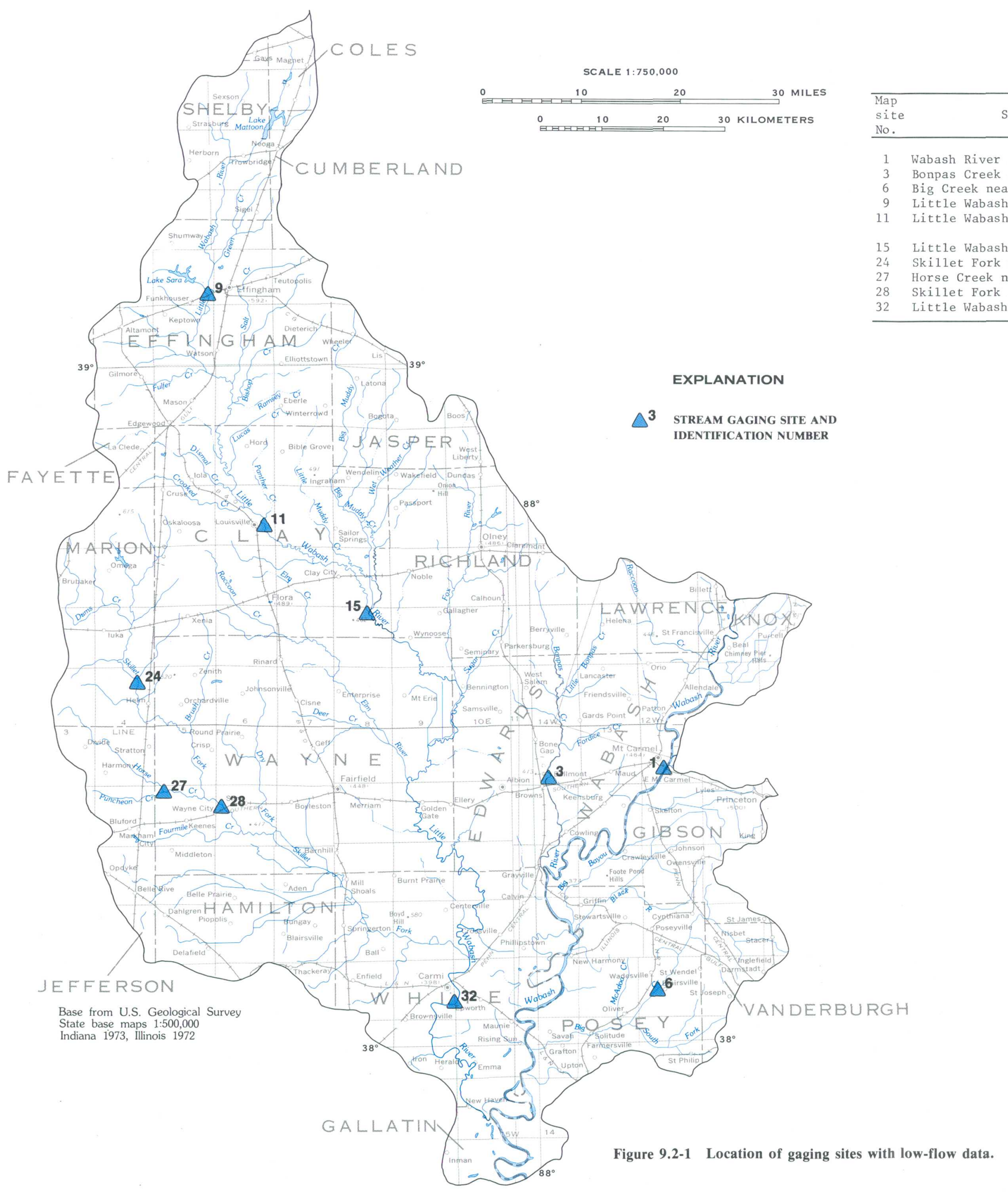

Table 9.2-1 Calculated low-flow values for Area 31 stream gaging sites, in cubic feet per second.

\begin{tabular}{|c|c|c|c|c|c|c|c|c|}
\hline \multirow{2}{*}{ Site name } & \multirow{2}{*}{$\begin{array}{l}\text { Drainage } \\
\text { area } \\
\left(\min ^{2}\right) \\
\end{array}$} & \multirow{2}{*}{$\begin{array}{l}\text { No. of } \\
\text { years of } \\
\text { record }\end{array}$} & \\
\hline & & & $2 \mathrm{yr}$ & $5 \mathrm{yr}$. & $10 \mathrm{yr}$ & $20 \mathrm{yr}$. & $50 \mathrm{yr}$ & $100 \mathrm{yr}$ \\
\hline bash River at Mount Carme1, II & 28,635 & $\begin{array}{r}55 \\
42\end{array}$ & 3,930 & 2,770 & & 1,980 & 1,670 & \\
\hline $\begin{array}{l}\text { Bonpas Creek at B } \\
\text { Big Creek near Wa }\end{array}$ & $\begin{array}{l}228 \\
104\end{array}$ & $\begin{array}{l}42 \\
17\end{array}$ & $\begin{array}{l}0.01 \\
0.02\end{array}$ & $\begin{array}{l}0.00 \\
0.00\end{array}$ & $\begin{array}{l}0.00 \\
0.00\end{array}$ & 0.00 & 0.00 & 0.00 \\
\hline Little Wabash River near Effing & 240 & 16 & 0.00 & 0.00 & 0.00 & 0.00 & 0.00 & 0.00 \\
\hline Little Wabash River at Louisvill & 745 & 17 & 7.15 & 3.62 & 2.50 & & & 0.98 \\
\hline tle & & 68 & & & & 0.60 & & \\
\hline$c r$ & & 17 & & & & & & \\
\hline $\begin{array}{l}\text { se Creek near Keenes, I11. } \\
\text { 1let Fork at Wayne City }\end{array}$ & 97.2 & 23 & 0.00 & 0.00 & 0. & 0.00 & 0.00 & 0.00 \\
\hline Little Wabash River at Carmi & 3,102 & 43 & 24.5 & 10.2 & $\begin{array}{l}0.08 \\
6.10\end{array}$ & $\begin{array}{l}0.04 \\
3.85\end{array}$ & 2.20 & $\begin{array}{l}0.00 \\
1.49\end{array}$ \\
\hline
\end{tabular}

\section{STREAM GAGING SITE AND}

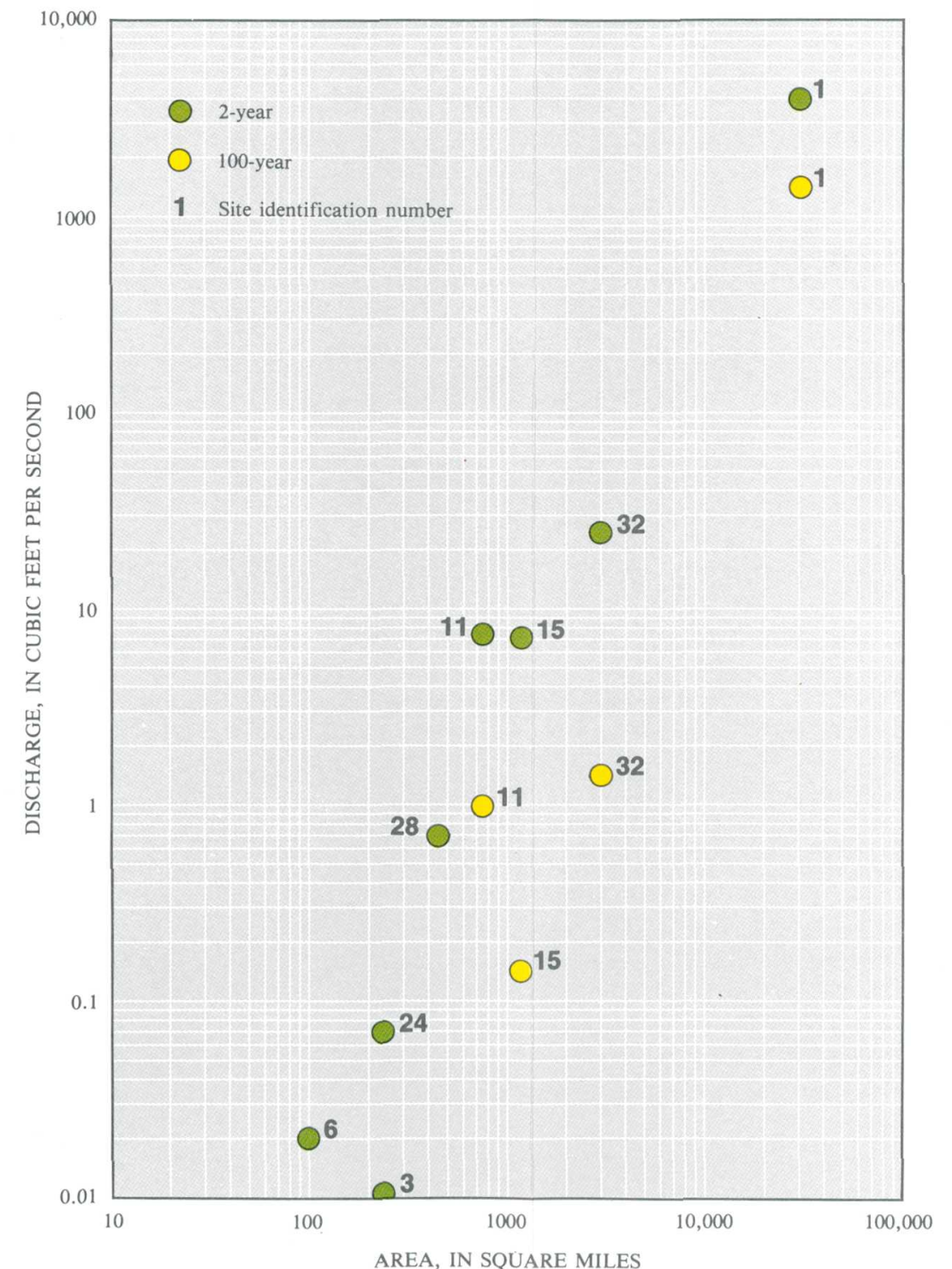

Figure 9.2-2 Relation between the 7-day, 2- and 100-year low flow and drainage area at stream gaging sites. 


\subsection{SURFACE-WATER QUANTITY--Continued \\ 9.3 High Flow}

\section{HIGH FLOWS CAN BE ESTIMATED}

\section{The relation of flood volumes or peak discharges to drainage area and slope at 10 gaged sites in Area 31 can be used to estimate flood volumes and peak discharges at ungaged sites.}

High flows in streams occur when there is large quantities of rainfall and/or rapid snowmelt. Flood volumes and peak discharges for 10 continuousrecord gaging sites and 7 crest-stage partial-record sites in Area 31 (fig. 9.3-1) were computed using a log-Pearson Type III distribution (Meeks, 1983, p. G-5).

The 7-day, 5-, 10-, 50-, and 100-year flood volume values at ungaged sites can be estimated using the following equations:

$$
\begin{aligned}
& V_{7,5}=33.6 A^{0.83} \\
& V_{7,10}=39.0 A^{0.83} \\
& V_{7,50}=49.0 \quad A^{0.83} \\
& V_{7,100}=52.6 \quad A^{0.83}
\end{aligned}
$$

The 7-day, $\mathrm{X}$-year flood volume $\left(V_{7,5}\right)$ is the highest 7-consecutive-day mean discharge, in cubic feet per second, expected to be exceeded at intervals averaging $X$ years where $X$ is $5,10,50$, or 100 years. The drainage area $(A)$ is in square miles. The relation of the 7-day, 10-year flood volume to the drainage areas of 10 gaging sites is presented in figure 9.3-2.
Annual peak discharges can also be estimated using the following equations developed by Curtis (1977):

$$
\begin{aligned}
& Q_{5}=65.5 A^{0.769} S^{0.485} \\
& Q_{10}=83.7 A^{0.767} S^{0.494} \\
& Q_{50}=123 A^{0.763} S^{0.510} \\
& Q_{100}=140 A^{0.762} S^{0.515}
\end{aligned}
$$

The annual peak discharge $\left(Q_{t}\right)$, in cubic feet per second, will be exceeded at intervals averaging $t$ years in length where $t$ is $5,10,50$, or 100 years. The drainage area $(A)$ is in square miles. The slope of the river channel (S), in units of feet of fall per mile of channel, is based on the difference of elevations divided by the distance between points located at 10 and 85 percent of the total distance along the low-water channel from the site to the basin divide. The peak-discharge equations are based on data from 14 gaging sites. Peak-discharge and high-flow values for area gaging sites are shown in table 9.3-1. 


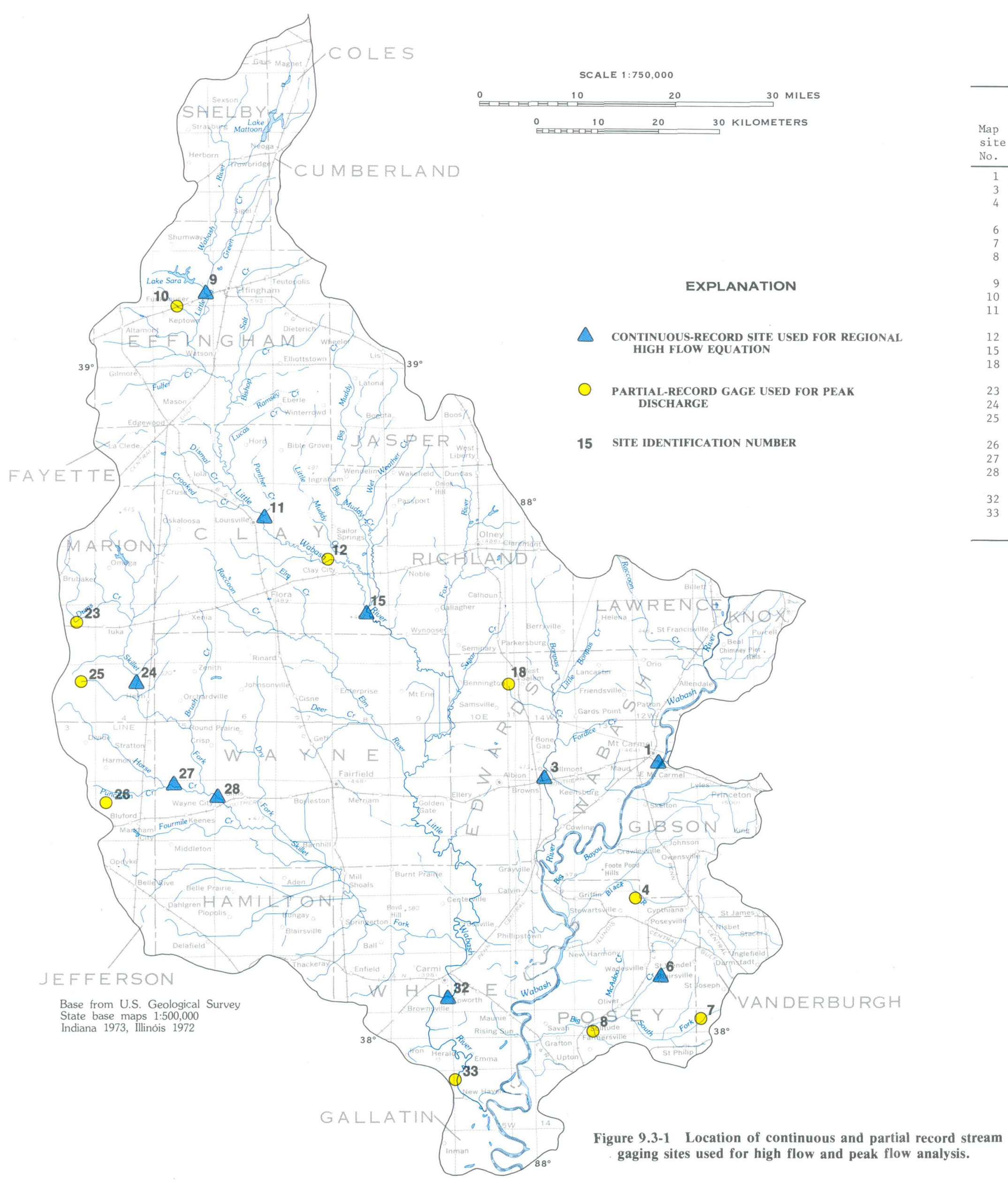

Table 9.3-1 The 5-, 10-, 50-, and 100-year, 7-day high-flow and peak-discharge value

\begin{tabular}{|c|c|c|c|c|c|c|c|c|c|c|}
\hline \multirow[b]{2}{*}{$\begin{array}{l}\text { Map } \\
\text { site } \\
\text { No. }\end{array}$} & \multirow[b]{2}{*}{ Site name } & \multirow[b]{2}{*}{$\begin{array}{c}\text { Drainage } \\
\text { areac } \\
\text { mi }^{2}\end{array}$} & \\
\hline & & & $v_{7,5}$ & $v_{7,10}$ & $v_{7,50}$ & $v_{7,100}$ & $Q_{5}$ & & $Q_{50}$ & $Q_{100}$ \\
\hline $\begin{array}{l}1 \\
3 \\
4\end{array}$ & $\begin{array}{l}\text { Wabash River at Mount Carmel, I11. } \\
\text { Bonpas Creek at Brovns, I11. II. Ind. } \\
\text { Black River near Poseyvil1e, Ind. }\end{array}$ & $\begin{array}{c}28,635 \\
228 \\
22.9\end{array}$ & $\begin{array}{l}182,000 \\
3,020 \\
\mathrm{~A}\end{array}$ & $\begin{array}{c}209,000 \\
3,200 \\
\mathrm{~A}\end{array}$ & $\begin{array}{c}247,000 \\
3,320 \\
A\end{array}$ & $\underset{\mathrm{A}}{258,000}$ & ${ }_{3,300}^{B}$ & $\underset{B}{5,250}$ & $\underset{B}{\mathrm{~B}, 150}$ & $\begin{array}{c}\mathrm{B} \\
7,960 \\
B\end{array}$ \\
\hline & $\begin{array}{l}\text { Big Creek near Wadesville, Ind. } \\
\text { Little Creek tributary near Kasson, Ind. } \\
\text { olive Creek Tributary near Solitude, Ind. }\end{array}$ & $\begin{array}{r}104 \\
0.40 \\
0.32\end{array}$ & $\underset{\substack{1,600 \\
\mathrm{~A}}}{\mathrm{~A}}$ & 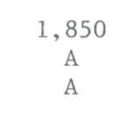 & 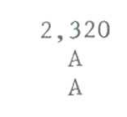 & $\begin{array}{c}2,490 \\
\mathrm{~A} \\
\mathrm{~A}\end{array}$ & $\begin{array}{l}\mathrm{B} \\
\mathrm{B} \\
\mathrm{B}\end{array}$ & $\begin{array}{l}\text { B } \\
\text { B } \\
\text { B }\end{array}$ & $\begin{array}{l}\mathrm{B} \\
\mathrm{B} \\
\mathrm{B}\end{array}$ & $\begin{array}{l}\mathrm{B} \\
\mathrm{B} \\
\mathrm{B}\end{array}$ \\
\hline 10 & $\begin{array}{l}\text { Little Wabash River near Effingham, I11. } \\
\text { Second Creek tributary at Keptown, II1. } \\
\text { Littele Wabash River at Louisville, ,111. }\end{array}$ & $\begin{array}{l}240 \\
745 \\
74.62\end{array}$ & $\begin{array}{l}2,480 \\
40 \\
8,100\end{array}$ & $\begin{array}{l}3,060 \\
\text { A } \\
9,720\end{array}$ & $\begin{array}{r}4,400 \\
A \\
13,200\end{array}$ & $\begin{array}{c}5,000 \\
\text { A } \\
14,700\end{array}$ & $\begin{array}{c}B \\
408 \\
17,000\end{array}$ & $\underset{51,500}{B}$ & $\begin{array}{c}\text { B } \\
805 \\
31,1003\end{array}$ & $\begin{array}{c}\mathrm{B} \\
923 \\
35,100\end{array}$ \\
\hline & 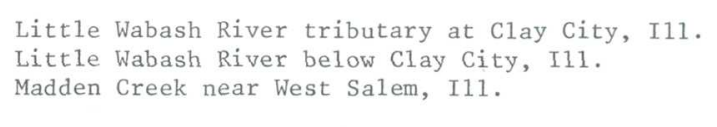 & $\cdot \begin{array}{r}0.43 \\
1,131 \\
1.62\end{array}$ & $\underset{13,100}{A}$ & $\underset{15,400}{A}$ & $\stackrel{\substack{A \\
A}}{18,600}$ & $\underset{19,4002}{A}$ & $\begin{array}{r}257 \\
23,000 \\
673\end{array}$ & $\begin{array}{r}338 \\
30,300 \\
837\end{array}$ & $\begin{array}{r}525 \\
47,3005 \\
1,200\end{array}$ & $\begin{array}{r}606 \\
54,500 \\
1,350\end{array}$ \\
\hline $\begin{array}{l}23 \\
24\end{array}$ & $\begin{array}{l}\text { Dums Creek tributary near Iuka, I11. } \\
\text { Skillet Fork near Iuka, I111. } \\
\text { Horse Creek tributary near Cartter, } \\
\text { Hil. }\end{array}$ & $\begin{array}{r}0.08 \\
208 \\
1.13\end{array}$ & $\underset{3,010}{A}$ & 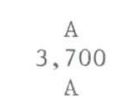 & $\stackrel{\stackrel{A}{A}, 940}{A}$ & 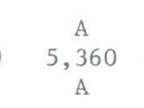 & $\begin{array}{r}80 \\
8,910 \\
387\end{array}$ & $\begin{array}{r}104 \\
11,600 \\
498\end{array}$ & $\begin{array}{l}161 \\
17,8002 \\
744\end{array}$ & $\begin{array}{r}187 \\
20,100 \\
854\end{array}$ \\
\hline $\begin{array}{l}26 \\
27\end{array}$ & $\begin{array}{l}\text { White Feather Creek near Marlow, } 111 . \\
\text { Horse Creek near Keenes, I11. } \\
\text { Ski11et Fork at Wayne City, I11. }\end{array}$ & $\begin{array}{l}0.43 \\
97.2 \\
464\end{array}$ & $\begin{array}{c}A \\
1,580 \\
6,610\end{array}$ & $\begin{array}{l}A \\
1,780 \\
7,910\end{array}$ & $\stackrel{\substack{A \\
2,040 \\
9,920}}{2}$ & $\begin{array}{c}\mathrm{A} \\
2,100 \\
10,500\end{array}$ & $\begin{array}{r}255 \\
5,830 \\
14,100\end{array}$ & $\begin{aligned} 328 \\
7,2101 \\
18,3002\end{aligned}$ & $\begin{aligned} 491 \\
10,3001 \\
27,8003\end{aligned}$ & $\begin{array}{r}566 \\
11,400 \\
31,700\end{array}$ \\
\hline & $\begin{array}{l}\text { Little Wabash River at Carmi, I11. } \\
\text { Little Wabash River tributary near New Haven, } \\
\text { I11. }\end{array}$ & $\begin{array}{l}3,102 \\
0.16\end{array}$ & $\stackrel{20,900}{A}$ & 24,900 & $\underset{A}{31,900}$ & $\underset{\mathrm{A}}{34,2002}$ & $\begin{array}{l}3,0002 \\
152\end{array}$ & 191 & 279 & $\begin{aligned} 45,800 \\
318\end{aligned}$ \\
\hline
\end{tabular}

A Crest-stage gage, no high-flow values
B No peak discharge values available at this time

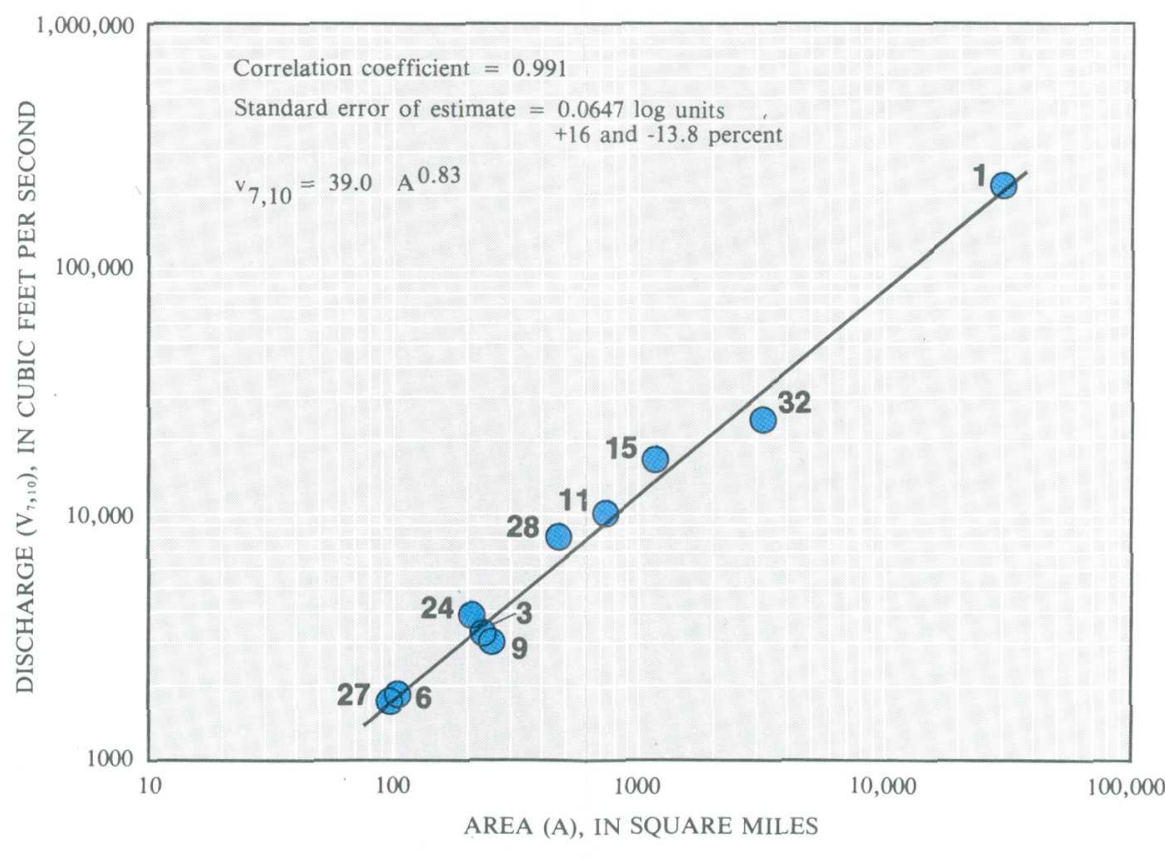

Figure 9.3-2 Relation between the 7-day, 10-year high flow and drainage area. 


\title{
9.0 SURFACE-WATER QUANTITY--Continued \\ 9.4 Flow Variability
}

\section{FLOW DURATION CURVES INDICATE VARIABLE STREAMFLOW CONDITIONS THROUGHOUT AREA}

\author{
Flow duration analysis of discharge records from 10 gaging \\ stations shows uniform high-flow characteristics \\ and variable low-flow characteristics.
}

Daily-discharge data were used in the flowduration analysis of records obtained at 10 gaging sites in Area 31 (fig. 9.4-1). The 95-, 90-, 75-, 70-, 50-, 25-, and 10-percent flow-duration values for each site are listed in table 9.4-1.

Flow duration is presented as curves for three area sites (figure 9.4-2). The site number 11 curve is representative of curves for sites 1,11 , and 32 . The site number 28 curve is representative of curves for sites 15,24 , and 28 . The site number 3 curve is representative of curves for sites $3,6,9$, and 27. The curves are almost parallel for the 10 to 50 percent of time range, which indicates that high-flow characteristics of streams in the area are similar. The low flow part of the curves (70 to 95 percent of time) have differing slopes. For site number 11 , the slope of the curve decreases and the curve becomes flatter, which indicates that the site has a sustained low flow; for site number 28 , the slope remains about constant; and for site number 3, the slope of the curve increases and the curve becomes steeper, which indicates that the site has a poorly sustained low flow.

The area under the flow-duration curve represents a value of the average discharge at the gaging station and the slope of the curve represents the variability of the stream discharge (Mitchell, 1957). Low flow, which is associated with the highpercent end of the flow-duration curve, represents ground water entering the stream through seeps and springs during periods of little precipitation and, in some instances, the discharge of industrial and municipal waste-disposal effluents. High flow, which is associated with the low-percent end of the curve, occurs with the addition of direct runoff from precipitation and/or melting snow or streamflow regulation. 


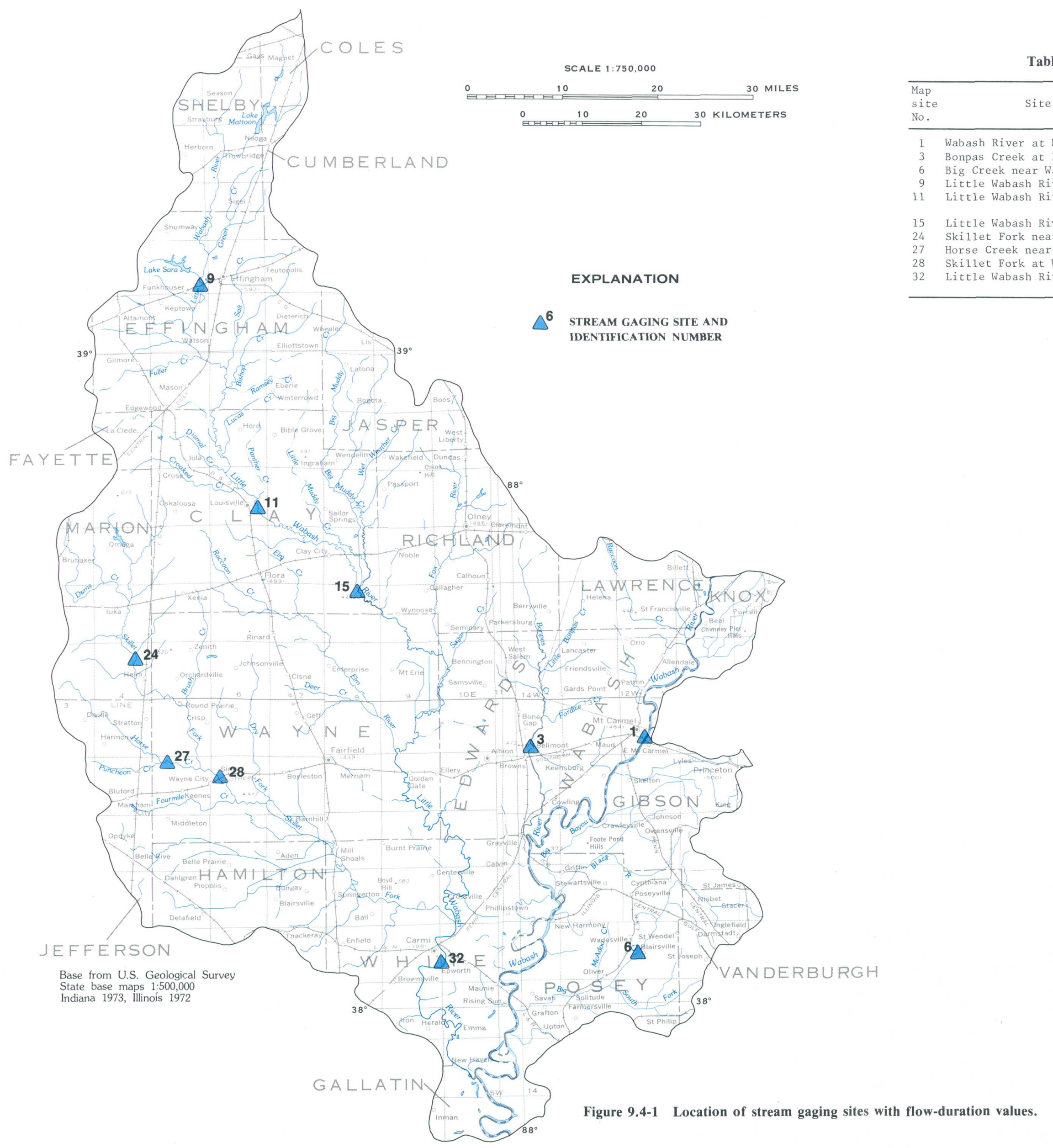

Table 9.4-1 Flow-duration discharge at Area 31 stream gaging sites, in cubic feet per second.

\begin{tabular}{|c|c|c|c|c|c|c|c|c|c|}
\hline \multirow{2}{*}{$\begin{array}{l}\text { Map } \\
\text { sit } \\
\text { No. }\end{array}$} & \multirow{2}{*}{ Site name } & \multirow{2}{*}{$\begin{array}{c}\text { Drainage } \\
\text { area } \\
\left(\mathrm{mi}^{2}\right)\end{array}$} & \multicolumn{7}{|c|}{ Percent of time discharge is exceeded } \\
\hline & & & 95 & 90 & 75 & 70 & 50 & 25 & 10 \\
\hline $\begin{array}{r}1 \\
3 \\
6 \\
9 \\
11\end{array}$ & 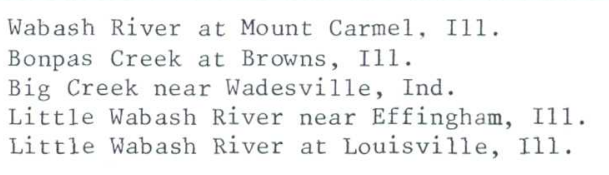 & $\begin{array}{r}28,635 \\
228 \\
104 \\
240 \\
745\end{array}$ & $\begin{array}{l}3,210 \\
0.00 \\
0.07 \\
0.01 \\
7.4\end{array}$ & $\begin{array}{l}4,070 \\
0.01 \\
0.25 \\
0.04 \\
12.3\end{array}$ & $\begin{array}{r}6,960 \\
1.6 \\
2.4 \\
9.7 \\
31.8\end{array}$ & $\begin{array}{r}8,040 \\
2.7 \\
3.9 \\
14.5 \\
39.9\end{array}$ & $\begin{array}{r}15,300 \\
17 \\
18.4 \\
41.3 \\
96.8\end{array}$ & $\begin{array}{l}35,500 \\
127 \\
67.2 \\
134 \\
355\end{array}$ & $\begin{array}{r}66,900 \\
768 \\
218 \\
413 \\
1,580\end{array}$ \\
\hline $\begin{array}{l}15 \\
24 \\
27 \\
28\end{array}$ & 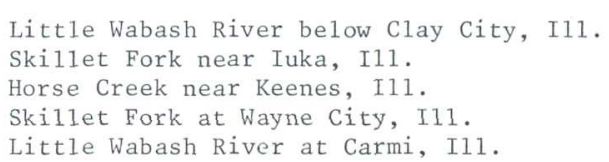 & $\begin{array}{l}1,131 \\
208 \\
97.2 \\
464 \\
3,102\end{array}$ & $\begin{array}{l}5.2 \\
0.18 \\
0.0 \\
0.63 \\
19.8\end{array}$ & $\begin{array}{c}10.3 \\
0.38 \\
0.01 \\
1.4 \\
34.4\end{array}$ & $\begin{array}{r}34.0 \\
1.9 \\
0.46 \\
5.8 \\
112\end{array}$ & $\begin{array}{c}46.0 \\
3.0 \\
0.90 \\
8.4 \\
154\end{array}$ & $\begin{array}{r}140 \\
13.7 \\
6.3 \\
33.2 \\
495\end{array}$ & $\begin{array}{c}635 \\
75.7 \\
36.7 \\
186 \\
3,310\end{array}$ & $\begin{array}{r}2,740 \\
402 \\
176 \\
1,070 \\
8,080\end{array}$ \\
\hline
\end{tabular}

STREAM GAGING STTE AND

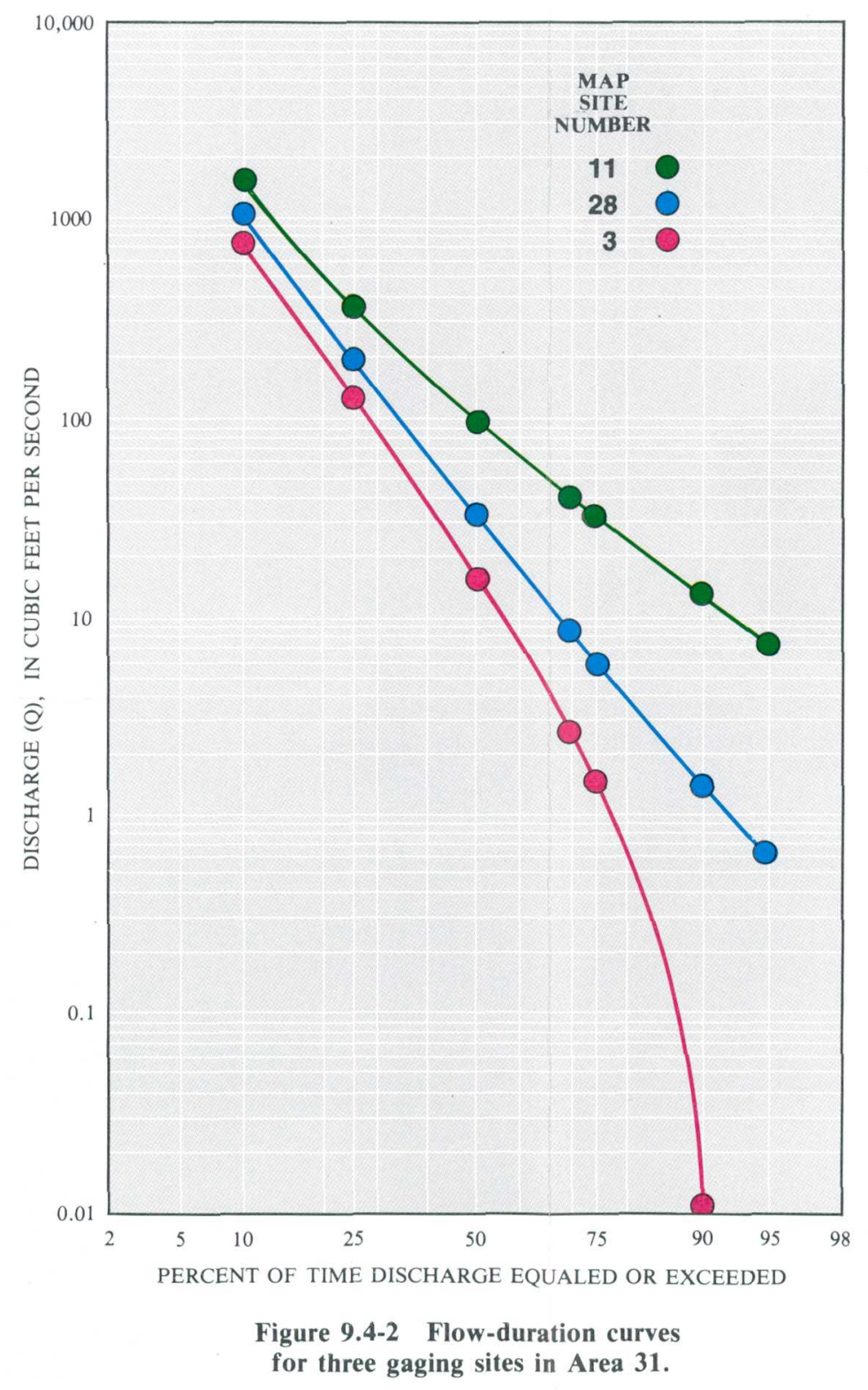




\title{
10.0 SURFACE-WATER QUALITY
}

10.1 Specific Conductance and Dissolved Solids

\section{SPECIFIC CONDUCTANCE CAN BE USED TO ESTIMATE DISSOLVED-SOLIDS CONCENTRATIONS}

\begin{abstract}
The relation between dissolved-solids concentration and specific conductance in water from 16 streams in Area 31 can be used to estimate dissolved-solids concentrations in the area.
\end{abstract}

An equation of the form $K A=S$ (Hem, 1970, p. 99) can be used to estimate the dissolved-solids concentrations in area streams. The specific conductance $(K)$ is in microsiemens per centimeter at $25^{\circ}$ Celsius $(\mu \mathrm{S} / \mathrm{cm})$, the dissolved-solids concentration $(S)$ is in milligrams per liter $(\mathrm{mg} / \mathrm{L})$, and the regression coefficient (A) is a dimensionless constant equal to 0.68 from a regression analysis of data from 16 area sites (fig. 10.1-1). Hem (1970, p. 99) states that the coefficient, $A$, is usually between 0.55 and 0.75 for natural waters (fig. 10.1-2).

Specific-conductance measurements at the 16 sites ranged from 120 to $2,200 \mu \mathrm{S} / \mathrm{cm}$; average values ranged from 253 to $1,750 \mu \mathrm{S} / \mathrm{cm}$ (table
10.1-1). Dissolved-solids concentrations were measured at 15 of the sites and ranged from 112 to $2,410 \mathrm{mg} / \mathrm{L}$; average concentrations ranged from 200 to $672 \mathrm{mg} / \mathrm{L}$ (table $10.1-2$ ).

Area 31 has only one active coal mine, and it is an underground mine. Those areas that have been surface mined cannot account for the relatively high specific conductance values and dissolved-solids concentrations that have occurred throughout the area. These occurrences may be attributable to agricultural runoff, septic tank leachate, and oil wells (Illinois Environmental Protection Agency, 1976). 


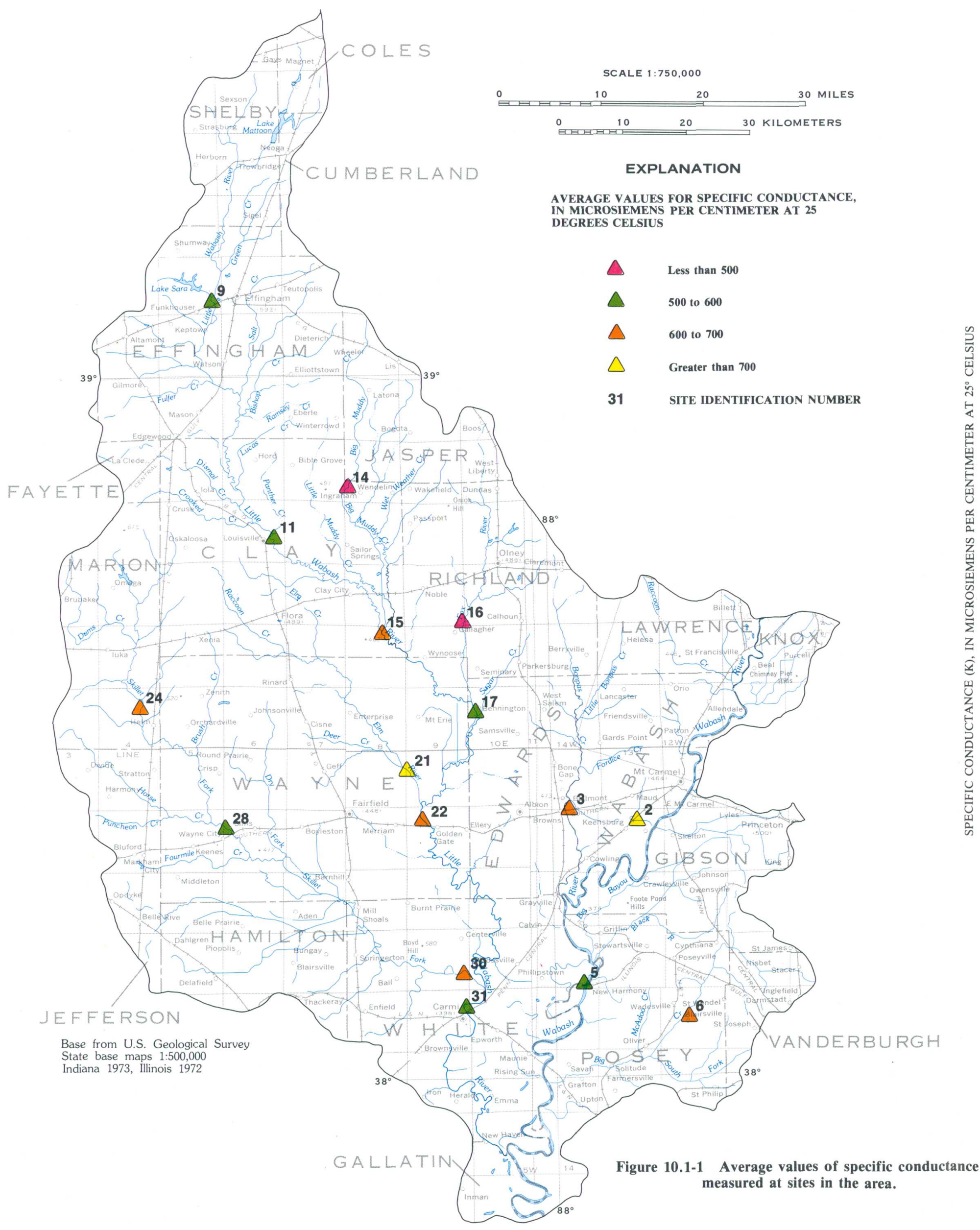

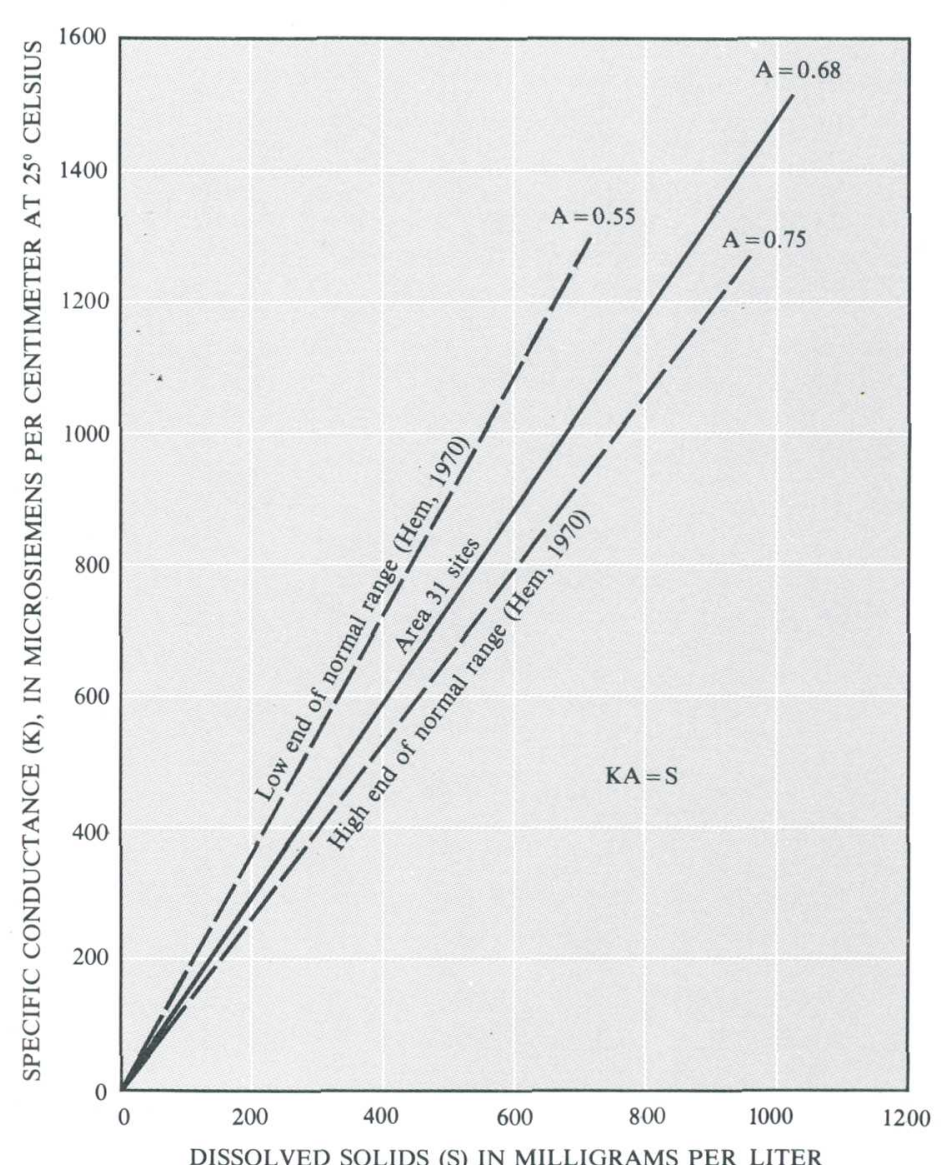

DISOLVED SOUIDS TIN IN MULGRAMS PER HTER

Figure 10.1-2 Relation between specific conductance and dissolved solids in Area 31.
Table 10.1-1 Specific conductance at 16 sites in Area 31.

Specific conductance, in microsiemens

\begin{tabular}{ccccc} 
Map & Number & \multicolumn{3}{c}{ at $25^{\circ}$ Celsius } \\
\cline { 3 - 5 } $\begin{array}{c}\text { of } \\
\text { ofte } \\
\text { No. }\end{array}$ & samples & Minimum & Average & Maximum \\
\hline 2 & 1 & 1,750 & 1,750 & 1,750 \\
3 & 46 & 143 & 613 & 1,510 \\
5 & 65 & 240 & 518 & 785 \\
6 & 2 & 600 & 670 & 740 \\
& & & & \\
9 & 31 & 274 & 551 & 700 \\
11 & 55 & 149 & 539 & 930 \\
14 & 1 & 253 & 253 & 253 \\
15 & 33 & 185 & 663 & 1,100 \\
& & & & \\
16 & 1 & 311 & 311 & 311 \\
17 & 46 & 186 & 580 & 1,150 \\
21 & 34 & 365 & 903 & 2,200 \\
22 & 1 & 692 & 692 & 692 \\
24 & 46 & & & \\
24 & 46 & 252 & 546 & 1,372 \\
30 & 49 & 157 & 681 & 1,190 \\
31 & 30 & 167 & 526 & 1,580 \\
& & & & 840 \\
\hline
\end{tabular}

Table 10.1-2 Dissolved-solids concentrations at 15 sites

\begin{tabular}{|c|c|c|c|c|}
\hline \multirow{2}{*}{$\begin{array}{l}\text { Map } \\
\text { site } \\
\text { No. }\end{array}$} & \multirow{2}{*}{$\begin{array}{l}\text { Number } \\
\text { of } \\
\text { samples }\end{array}$} & \multicolumn{3}{|c|}{$\begin{array}{l}\text { Dissolved-solids } \\
\text { concentrations, in } \\
\text { milligrams per liter }\end{array}$} \\
\hline & & Minimum & Average & Maximum \\
\hline 3 & 10 & 200 & 472 & 810 \\
\hline 5 & 62 & 180 & 331 & 494 \\
\hline 6 & 2 & 379 & 380 & 380 \\
\hline 9 & 2 & 221 & 311 & 401 \\
\hline 11 & 23 & 187 & 449 & 2,410 \\
\hline 14 & 1 & 200 & 200 & 200 \\
\hline 15 & 9 & 330 & 423 & 640 \\
\hline 16 & 1 & 238 & 238 & 238 \\
\hline 17 & 9 & 155 & 392 & 680 \\
\hline 21 & 10 & 250 & 672 & 1,350 \\
\hline 22 & 1 & 398 & 398 & 398 \\
\hline 24 & 22 & 112 & 495 & 1,050 \\
\hline 28 & 10 & 225 & 446 & 890 \\
\hline 30 & 10 & 350 & 550 & 886 \\
\hline 31 & 26 & 118 & 339 & 507 \\
\hline
\end{tabular}




\title{
10.0 SURFACE-WATER QUALITY--Continued $10.2 \mathrm{pH}$
}

\section{AREA WATERS ARE NEUTRAL TO SLIGHTY BASIC}

\author{
Measurements of $\mathrm{pH}$ in area streams ranged from 6.2 to 9.5, \\ values common to natural waters.
}

Values of $\mathrm{pH}$ for 474 measurements at 16 sites in Area 31 (fig. 10.2-1) ranged from 6.2 to 9.5 (table 10.2-1). The maximum $\mathrm{pH}$ values for all sites ranged from 6.8 to 9.5 (fig. 10.2-2) and the minimum $\mathrm{pH}$ values for all sites ranged from 6.2 to 9.0 (fig. 10.2-3). For the survival of freshwater aquatic life, a $\mathrm{pH}$ range of 6.5 to 9.0 is recommended (U.S. Environmental Protection Agency, 1976, p. 178).

All streams had $\mathrm{pH}$ ranges similar to that of natural waters "not affected by pollution" ( 6.5 to 8.5) (Hem, 1970, p. 93) with the exception of one measurement at Coffee Creek at Keensburg, Illinois (9.0), and two measurements at the Wabash River at New Harmony, Indiana (9.1 and 9.5). A $\mathrm{pH}$ value of 7.0 indicates neutral conditions; lower values indicate acidic water, and higher values in- dicate basic water. Generally, the surface waters of Area 31 can be classified as neutral to slightly basic.

The $\mathrm{pH}$ of waters draining areas affected by surface coal mining may be affected by chemical reactions with sulfide minerals in mine spoils. $\mathrm{Ox}$ idation and hydrolysis of pyrite, marcasite, and other minerals containing sulfide result in the production of sulfuric acid. A permissible range of $\mathrm{pH}$ values for effluents from mined areas (6.0 to 9.0) was established by the Office of Surface Mining Reclamation and Enforcement (1979). Acid-mine drainage may lower the $\mathrm{pH}$ of waters in receiving streams. The limited data available did not indicate any impact from what little mining has taken place in the area. 


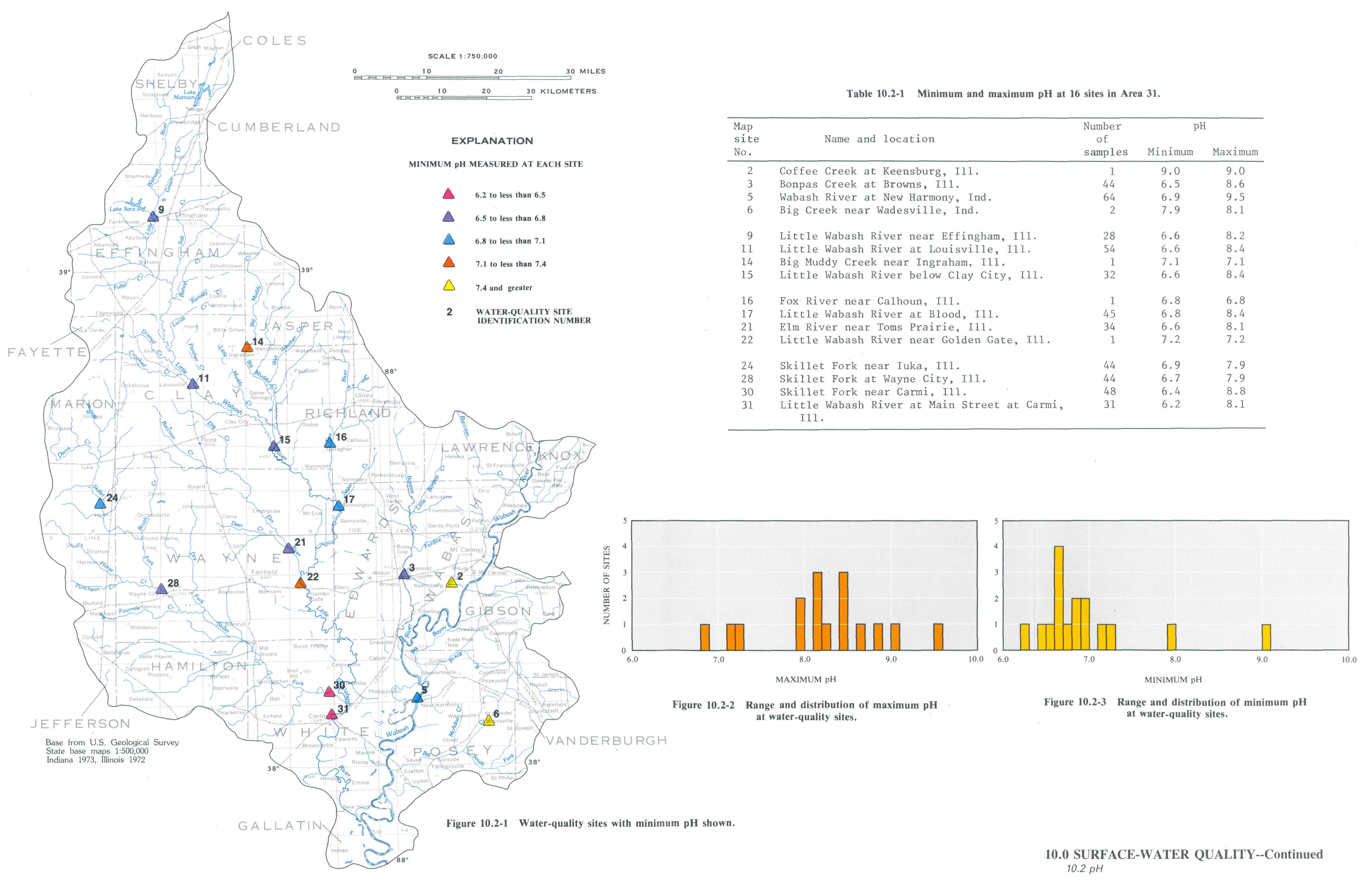




\title{
10.0 SURFACE-WATER QUALITY--Continued 10.3 Iron
}

\section{CONCENTRATIONS OF IRON VARY WIDELY IN AREA STREAMS}

\author{
Iron is abundant in Area 31 streams. Total-recoverable iron concentrations commonly \\ exceed the U.S. Environmental Protection Agency's recommended limit of \\ 1,000 micrograms per liter for freshwater aquatic life.
}

Iron is a common and abundant constituent of surface and ground water in Area 31. In streams, iron is present in dissolved and suspended phases. Total-recoverable iron (dissolved plus suspended iron) concentrations in streams ranged from 210 to 24,600 micrograms per liter $(\mu \mathrm{g} / \mathrm{L})$. Average concentrations of total-recoverable iron for sites with more than one sample ranged from 1,450 to 4,050 $\mu \mathrm{g} / \mathrm{L}$ (table 10.3-1). The average concentrations of total-recoverable iron for 294 samples at 16 stream sites was $2,980 \mu \mathrm{g} / \mathrm{L}$. Ranges of average concentrations are shown in figure 10.3-1.

Concentrations of total-recoverable iron commonly exceeded the limit of $1,000 \mu \mathrm{g} / \mathrm{L}$ for freshwater aquatic life and $300 \mu \mathrm{g} / \mathrm{L}$ for domestic use recommended by the U.S. Environmental Protection Agency (1976, p. 78). The Office of Surface Mining Reclamation and Enforcement (1979) established a maximum limit for total-recoverable iron of $7,000 \mu \mathrm{g} / \mathrm{L}$ in discharge water from areas disturbed by mining activities. This criterion was met in stream water at only 4 of the 16 sites. These high iron concentrations cannot be attributed to coal-mining activity.

Dissolved-iron concentrations ranged from 10 to $1,400 \mu \mathrm{g} / \mathrm{L}$ and averaged $137 \mu \mathrm{g} / \mathrm{L}$ for 83 samples from 15 sites. Average dissolved-iron concentrations for sites with more than one sample ranged from 38 to $486 \mu \mathrm{g} / \mathrm{L}$ (table 10.3-2). Ranges of average concentration are shown in figure 10.3-2.

The solubility of iron is inversely related to $\mathrm{pH}$. Mining can increase the amount of iron available to streams by exposing iron-bearing minerals to weathering processes. Iron is an essential element to plants and animals; it is vital to the oxygen transport mechanism in the blood of all vertebrate animals, and its absence in plants can be a limiting growth factor. 


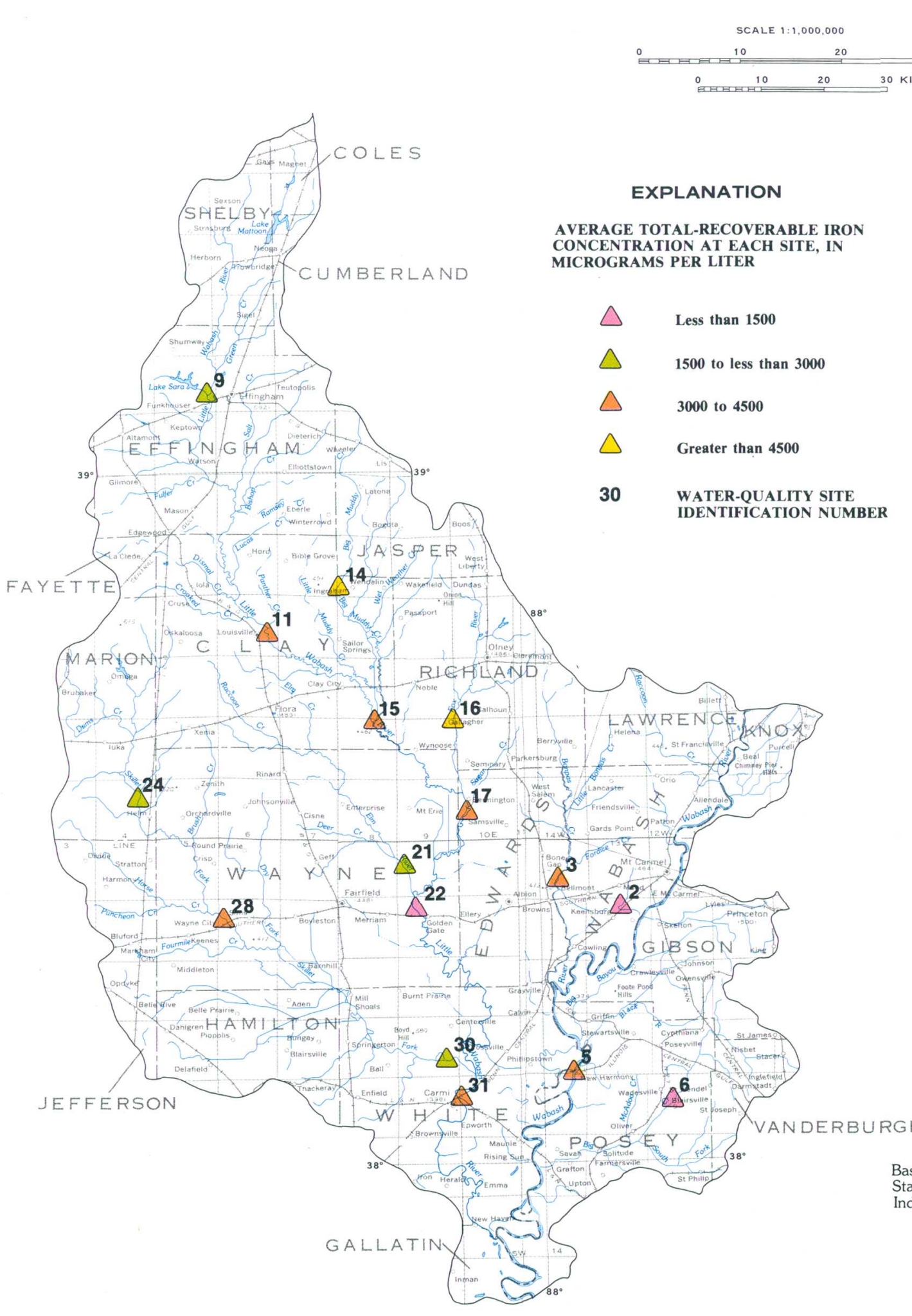

Figure 10.3-1 Average total-recoverable iron concentrations at water-quality sites.
EXPLANATION

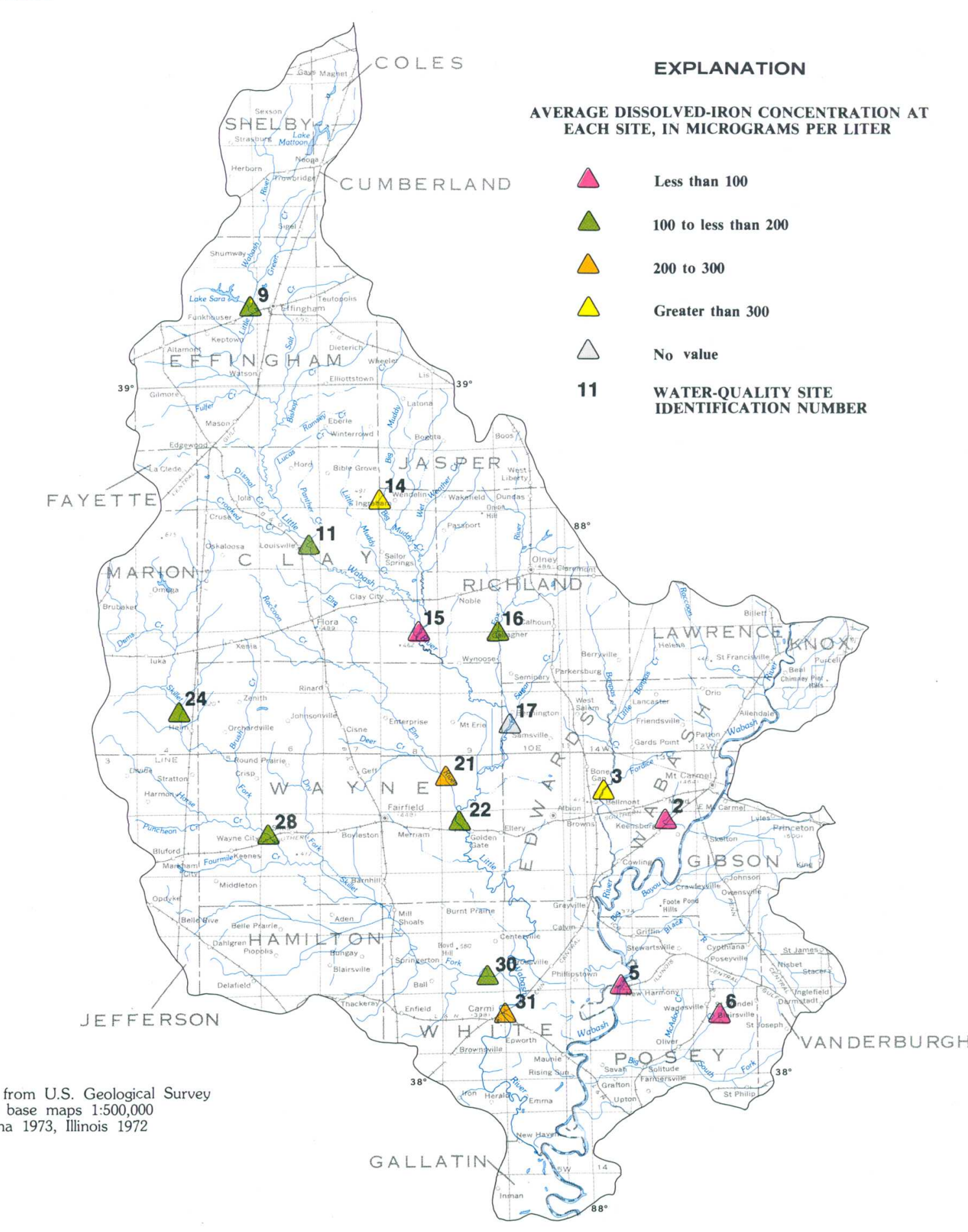

Table 10.3-1 Total-recoverable iron concentrations at 16 sites in Area 31.

\begin{tabular}{|c|c|c|c|c|}
\hline \multirow{2}{*}{$\begin{array}{l}\text { Map } \\
\text { site } \\
\text { No. }\end{array}$} & \multirow{2}{*}{$\begin{array}{c}\text { Number } \\
\text { of } \\
\text { samples }\end{array}$} & \multicolumn{3}{|c|}{$\begin{array}{l}\text { Total-recoverable iron } \\
\text { concentrations, in } \\
\text { micrograms per liter }\end{array}$} \\
\hline & & Minimum & Average & Maximum \\
\hline 2 & 1 & 830 & 830 & 830 \\
\hline 3 & 24 & 520 & 3,250 & 11,500 \\
\hline 5 & 26 & 310 & 3,090 & 9,000 \\
\hline 6 & 2 & 1,200 & 1,450 & 1,700 \\
\hline 9 & 25 & 330 & 1,610 & 15,000 \\
\hline 11 & 36 & & 4,010 & 24,600 \\
\hline 14 & 1 & 15,000 & 15,000 & 15,000 \\
\hline 15 & 21 & 1,200 & 3,930 & 16,000 \\
\hline 16 & 1 & 7,800 & 7,800 & 7,800 \\
\hline $\begin{array}{l}17 \\
21\end{array}$ & $\begin{array}{l}23 \\
25\end{array}$ & $\begin{array}{l}1,100 \\
600\end{array}$ & $\begin{array}{l}3,230 \\
2,280\end{array}$ & $\begin{array}{l}9,600 \\
8,700\end{array}$ \\
\hline 22 & 1 & 1,300 & 1,300 & 1,300 \\
\hline & 37 & 210 & 1,620 & 5,400 \\
\hline${ }^{28}$ & 28 & $\begin{array}{l}440 \\
400\end{array}$ & 3,280 & 22,000 \\
\hline $\begin{array}{l}30 \\
31\end{array}$ & $\begin{array}{l}23 \\
20\end{array}$ & $\begin{array}{l}280 \\
420\end{array}$ & $\begin{array}{l}2,530 \\
4,050\end{array}$ & $\begin{array}{r}1,300 \\
15,000\end{array}$ \\
\hline
\end{tabular}
Table 10.3-2 Dissolved-iron concentrations at 15

\begin{tabular}{|c|c|c|c|c|}
\hline \multirow{2}{*}{$\begin{array}{l}\text { Map } \\
\text { site } \\
\text { No. }\end{array}$} & \multirow{2}{*}{$\begin{array}{c}\text { Number } \\
\text { of } \\
\text { samples }\end{array}$} & \multicolumn{3}{|c|}{$\begin{array}{l}\text { Dissolved-iron concentrations, } \\
\text { in micrograms per liter }\end{array}$} \\
\hline & & Minimum & Average & Maximum \\
\hline 2 & 1 & 90 & 90 & 90 \\
\hline 3 & 3 & 67 & 486 & 1,000 \\
\hline 5 & 25 & 10 & 38 & 280 \\
\hline 6 & 2 & 20 & 43 & 70 \\
\hline & 2 & 160 & 195 & 230 \\
\hline 11 & 15 & & 145 & \\
\hline & 1 & 370 & 370 & 370 \\
\hline 15 & 1 & $10^{\circ}$ & 10 & 10 \\
\hline 16 & 1 & 110 & 110 & 110 \\
\hline 21 & 3 & 70 & 237 & 440 \\
\hline $\begin{array}{l}22 \\
24\end{array}$ & 1 & $\begin{array}{l}120 \\
10\end{array}$ & 120 & $\begin{array}{l}120 \\
340\end{array}$ \\
\hline & & 10 & 141 & \\
\hline 28 & 3 & 50 & 101 & 170 \\
\hline 30 & 1 & 110 & 110 & 0 \\
\hline 31 & 11 & 20 & 234 & 1,400 \\
\hline
\end{tabular}




\title{
10.0 SURFACE-WATER QUALITY--Continued \\ 10.4 Manganese
}

\section{CONCENTRATIONS OF MANGANESE EXCEED RECOMMENDED CRITERIA}

\author{
Manganese is abundant in Area 31 streams. Concentrations of manganese \\ in all samples exceeded the domestic water-supply criterion of \\ 50 micrograms per liter and two samples exceeded the \\ mine-effluent limitations of 4,000 micrograms per liter.
}

Total-recoverable manganese concentrations ranged from 50 to 5,000 micrograms per liter $(\mu \mathrm{g} / \mathrm{L})$ at 16 sites (fig. 10.4-1). Average concentrations of total-recoverable manganese for area sites ranged from 170 to $1,100 \mu \mathrm{g} / \mathrm{L}$ (table 10.4-1); the average for 290 samples from all sites was $610 \mu \mathrm{g} / \mathrm{L}$. Ranges of average concentrations of total recoverable manganese are shown in figure 10.4-1.

Dissolved manganese ranged from 1 to 4,000 $\mu \mathrm{g} / \mathrm{L}$ at 15 sites (fig. 10.4-2). Average concentrations of dissolved manganese for sites in the area ranged from 22 to $1,720 \mu \mathrm{g} / \mathrm{L}$ (table 10.4-2); the average for 83 values from all sites was $276 \mu \mathrm{g} / \mathrm{L}$. Ranges of average concentrations of dissolved manganese are shown in figure 10.4-2. A maximum allowable concentration of less than $50 \mu \mathrm{g} / \mathrm{L}$ is recommended for domestic water supplies to prevent staining of laundry and objectionable tastes (U.S. Environmental Protection Agency, 1976, p. 96). Average concentrations of both totalrecoverable and dissolved manganese in the study area commonly exceeded $50 \mu \mathrm{g} / \mathrm{L}$. The mine effluent limitations for total-recoverable manganese of $4,000 \mu \mathrm{g} / \mathrm{L}$, established by the Office of Surface Mining Reclamation and Enforcement (1979), was exceeded in stream water at two sites.

Manganese is an element widely distributed in igneous rocks and soils, but its total abundance in the Earth's crust is small enough to consider it a minor element. Manganese and iron are chemically similar. However, manganese usually stays in solution longer than iron. As the acidity of stream water is gradually neutralized, iron oxidizes to ferric hydroxide and precipitates (Hem, 1970, p. 130). Manganese is vital for both plants and animals (U.S. Environmental Protection Agency, 1976, p. 95). Inadequate amounts can inhibit plant growth or adversely affect animal reproduction. 


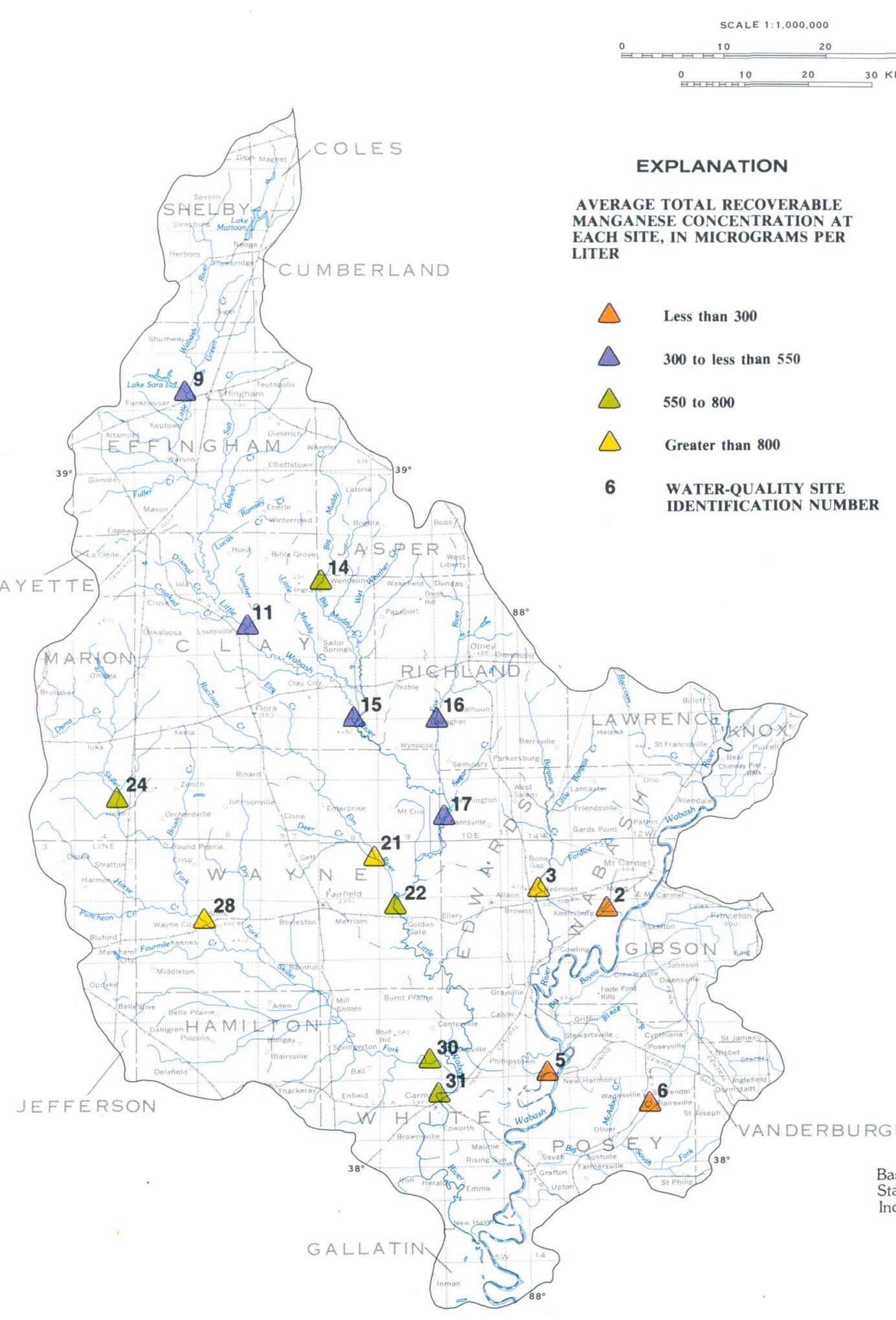

Figure 10.4-1 Average total-recoverable manganese concentration at water-quality sites.

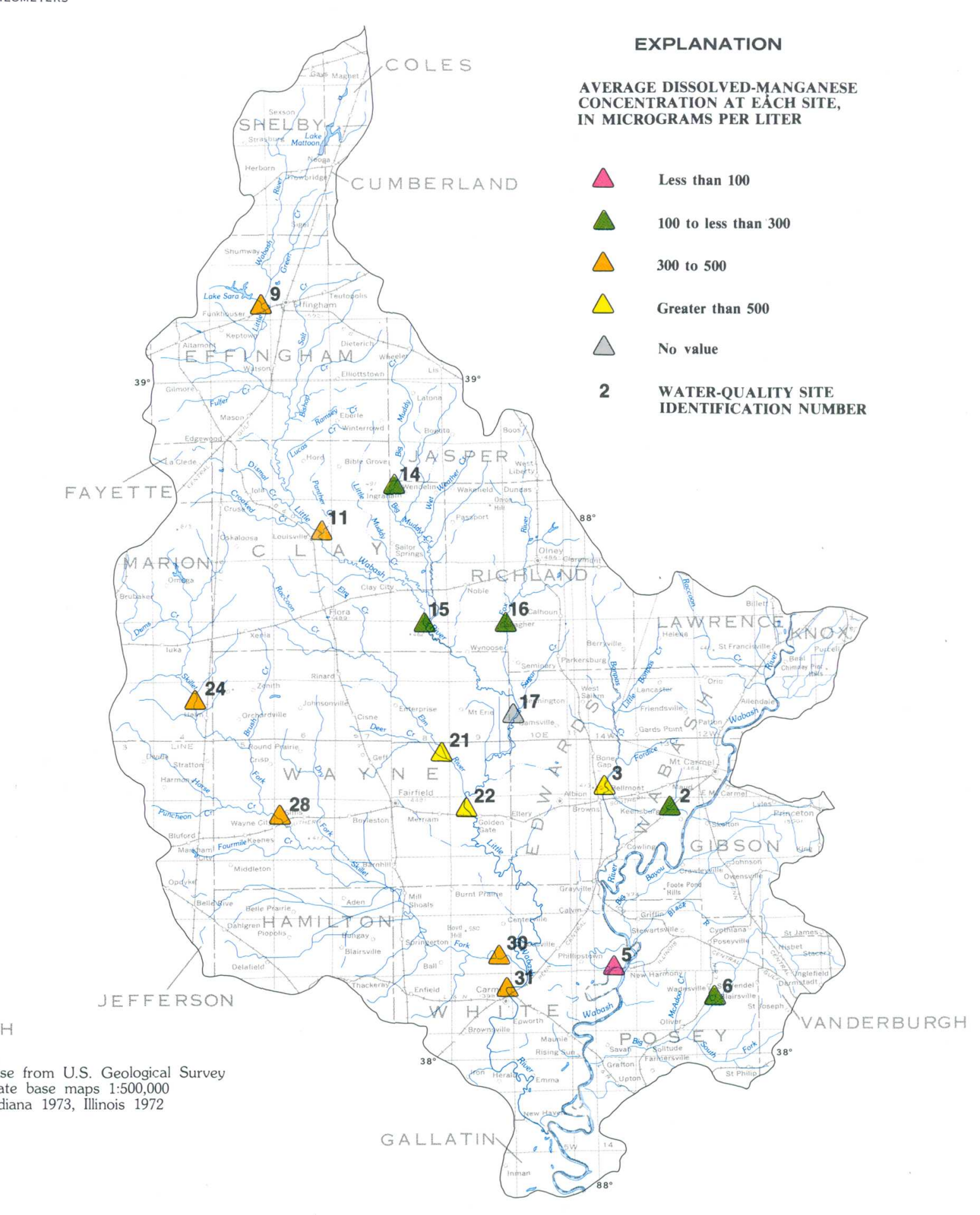

Figure 10.4-2 Average dissolved-manganese concentration at water-quality sites.
Table 10.4-1 Total-recoverable manganese concentrations at 16 sites in Area 31.

\begin{tabular}{|c|c|c|c|c|}
\hline \multirow{2}{*}{$\begin{array}{l}\text { Map } \\
\text { site } \\
\text { No. }\end{array}$} & \multirow{2}{*}{$\begin{array}{l}\text { Number } \\
\text { of } \\
\text { samples }\end{array}$} & \multicolumn{3}{|c|}{$\begin{array}{l}\text { Tota1-recoverable manganese } \\
\text { concentrations, in } \\
\text { micrograms per liter }\end{array}$} \\
\hline & & Minimum & Average & Maximum \\
\hline 2 & 1 & 170 & 170 & 170 \\
\hline 3 & 24 & 190 & 1,100 & 5,000 \\
\hline 5 & 25 & 90 & 212 & 490 \\
\hline 6 & 2 & 200 & 235 & 270 \\
\hline 9 & 25 & 100 & 349 & 1,230 \\
\hline 11 & 36 & 70 & 433 & 1,640 \\
\hline 14 & 1 & 600 & 600 & 600 \\
\hline 15 & 21 & 150 & 406 & 1,150 \\
\hline 16 & 1 & 300 & 300 & 300 \\
\hline 17 & 23 & & & \\
\hline 21 & 25 & 150 & 920 & 2,200 \\
\hline 22 & 1 & 780 & 780 & 780 \\
\hline 24 & 35 & 140 & 629 & 1,600 \\
\hline 28 & 27 & 15 & & 4,600 \\
\hline 30 & 23 & 26 & 698 & 2,400 \\
\hline 31 & 20 & 271 & 623 & 1,200 \\
\hline
\end{tabular}

Table 10.4-2 Dissolved-manganese concentrations at 15 sites in Area 31.

\begin{tabular}{|c|c|c|c|c|}
\hline \multirow{2}{*}{$\begin{array}{l}\text { Map } \\
\text { site } \\
\text { No. }\end{array}$} & \multirow{2}{*}{$\begin{array}{l}\text { Number } \\
\text { of } \\
\text { samples }\end{array}$} & \multicolumn{3}{|c|}{$\begin{array}{l}\text { Dissolved-manganese } \\
\text { concentrations, in } \\
\text { micrograms per iiter }\end{array}$} \\
\hline & & Minimum & Average & Maximun \\
\hline 2 & 1 & 100 & 100 & 100 \\
\hline 3 & 3 & 54 & 1,720 & 4,000 \\
\hline 5 & 25 & 1 & 22 & 150 \\
\hline 6 & 2 & 130 & 185 & 240 \\
\hline 9 & 2 & 81 & 340 & 600 \\
\hline 11 & 15 & 44 & 319 & 730 \\
\hline 14 & 1 & 220 & 220 & 220 \\
\hline 15 & 1 & 160 & 160 & 160 \\
\hline 16 & 1 & 140 & 140 & 140 \\
\hline 21 & 3 & 260 & 597 & 830 \\
\hline 22 & 1 & 720 & 720 & 720 \\
\hline 24 & 14 & 50 & 396 & 780 \\
\hline 28 & 3 & 230 & 420 & 720 \\
\hline 30 & 1 & 390 & 390 & 390 \\
\hline 31 & 10 & 160 & 475 & 910 \\
\hline
\end{tabular}




\title{
10.0 SURFACE-WATER QUALITY--Continued 10.5 Sulfate
}

\section{MODERATE SULFATE CONCENTRATIONS IN AREA STREAMS}

\begin{abstract}
The average concentration of dissolved sulfate in Area 31 streams is 68 milligrams per liter. One site had a maximum concentration of sulfate in excess of the criterion for domestic water supplies.
\end{abstract}

The measured concentrations of dissolved sulfate in 162 water samples obtained from 15 sites (fig. 10.5-1) ranged from 17 to 320 milligrams per liter $(\mathrm{mg} / \mathrm{L})$ and averaged $68 \mathrm{mg} / \mathrm{L}$ (table 10.5-1). The range of average concentrations was 32 to 130 . Ranges of average concentrations are shown in figure 10.5-1.

Sulfur is widely distributed in rocks as metallic sulfides, such as pyrite $\left(\mathrm{FeS}_{2}\right)$. Pyrite is commonly associated with biogenic deposits, such as coal (Hem, 1970, p. 162). During weathering, these sulfides come in contact with aerated water and are oxidized to yield sulfate ions. Although data are not available in Area 31 that demonstrate this process, it is common for sulfate concentrations to be higher at sites downstream of mining as a result of the increased weathering of sulfide minerals. This is demonstrated in Saline County, Illinois (Zuehls and others, 1981), which is adjacent to Area 31.

Toler (1982, p. 15) related annual sulfate loads to the area of surface mines as a percentage of total drainage area. He showed that, in southern Illinois, sulfate can be used as an indicator of mine drainage (fig. 10.5-2).

The recommended maximum concentration of sulfate in domestic water supplies is $250 \mathrm{mg} / \mathrm{L}$. Amounts in excess of this can cause physiological discomfort, undesirable tastes, and higher costs for water treatment (U.S. Environmental Protection Agency, 1976, p. 205). 


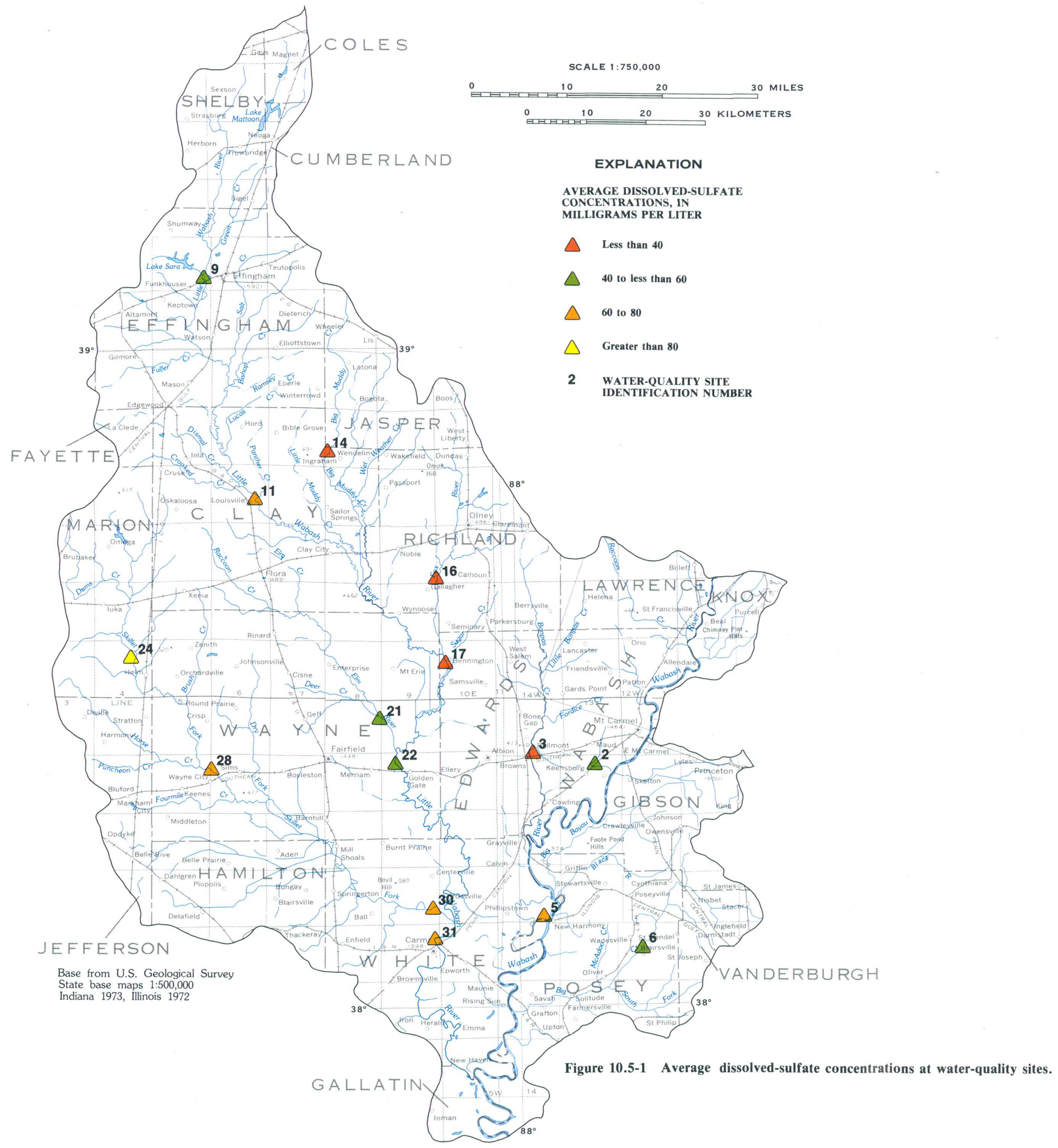

Table 10.5-1 Dissolved-sulfate concentrations at 15 sites in Area 31.

Dissolved-sulfate

\begin{tabular}{|c|c|c|c|c|}
\hline \multirow{2}{*}{$\begin{array}{l}\text { Map } \\
\text { site } \\
\text { No. }\end{array}$} & \multirow{2}{*}{$\begin{array}{c}\text { Number } \\
\text { of } \\
\text { samples }\end{array}$} & \multicolumn{3}{|c|}{$\begin{array}{l}\text { Dissolved-sulfate } \\
\text { concentrations, in } \\
\text { milligrams per liter }\end{array}$} \\
\hline & & Minimum & Average & Maximum \\
\hline 2 & 1 & 47 & 47 & 47 \\
\hline 3 & 2 & 35 & 37 & 39 \\
\hline 5 & 64 & 29 & 63 & 120 \\
\hline 6 & 2 & 44 & 45 & 47 \\
\hline 9 & 32 & 27 & 56 & 100 \\
\hline 11 & 13 & 27 & 77 & 240 \\
\hline 14 & 1 & 33 & 33 & 33 \\
\hline 16 & 1 & 39 & 39 & 39 \\
\hline 17 & 1 & 32 & 32 & 32 \\
\hline 21 & 2 & 45 & 49 & 53 \\
\hline 22 & 1 & 52 & 52 & 52 \\
\hline 24 & 13 & 30 & 130 & 320 \\
\hline 28 & 2 & 46 & 78 & 110 \\
\hline 30 & 1 & 80 & 80 & 80 \\
\hline 31 & 26 & 17 & 71 & 130 \\
\hline
\end{tabular}

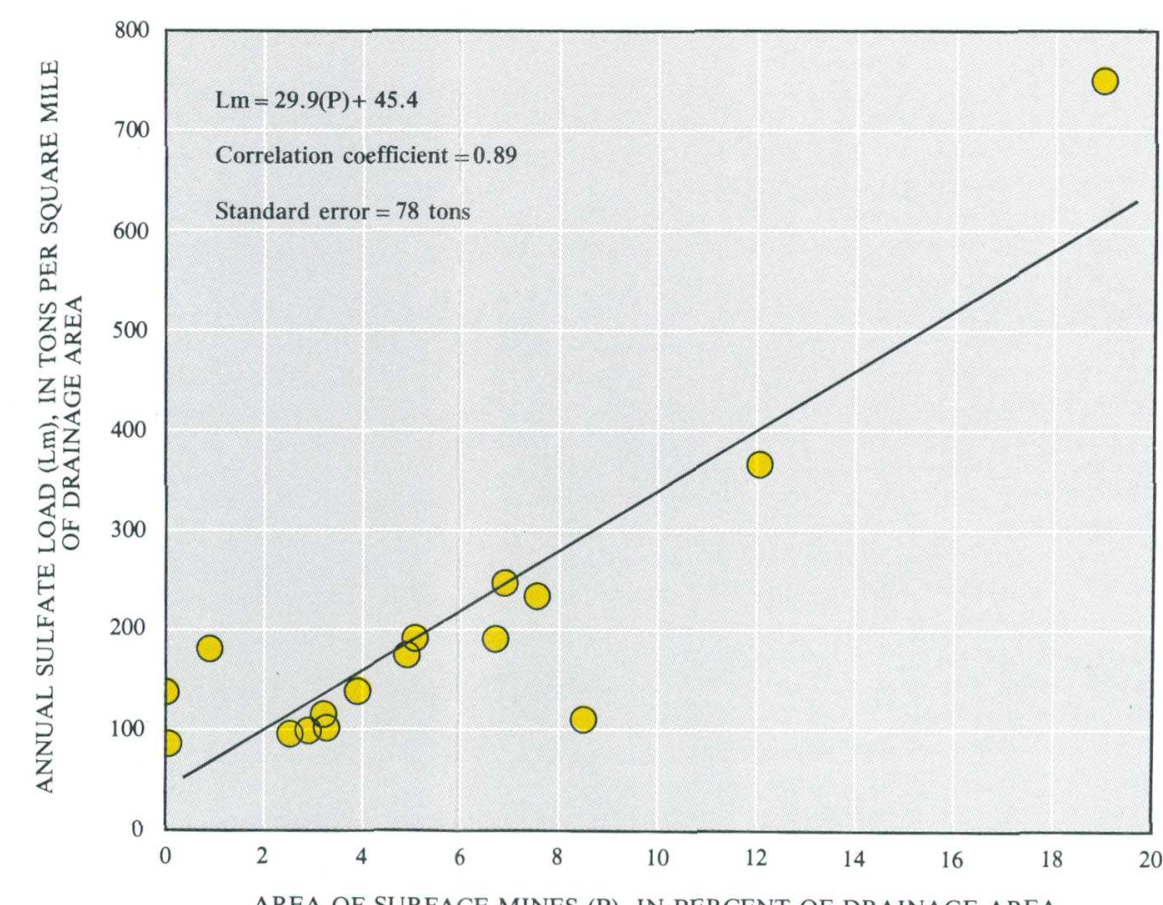

AREA OF SURFACE MINES (P), IN PERCENT OF DRAINAGE ARE

Figure 10.5-2 Relation of annual sulfate load per square mile of

10.0 SURFACE-WATER QUALITY--Continued 10.5 Sulfate 


\subsection{SURFACE-WATER QUALITY--Continued 10.6 Alkalinity}

\section{ALKALINITIES MODERATE IN AREA STREAMS}

The average alkalinity concentration was 137 milligrams per liter for streams in the area. Concentrations of 20 milligrams per liter or more are recommended for freshwater aquatic life to buffer acid influxes and reduce toxicity of heavy metals.

\begin{abstract}
Alkalinity concentrations commonly are reported as an equivalent amount of calcium carbonate $\left(\mathrm{CaCO}_{3}\right)$, in milligrams per liter $(\mathrm{mg} / \mathrm{L})$. Concentrations of alkalinity ranged from 24 to 290 $\mathrm{mg} / \mathrm{L}$ as $\mathrm{CaCO}_{3}$. The average concentration for 108 samples obtained from 13 sites (fig. 10.6-1) was 137 $\mathrm{mg} / \mathrm{L}$ (table 10.6-1). Average alkalinities ranged from 29 to $190 \mathrm{mg} / \mathrm{L}$ as $\mathrm{CaCO}_{3}$ at 13 sites. Ranges of average alkalinities are shown in figure 10.6-1.

Area streams generally have alkalinities sufficient to maintain a buffering capacity against
\end{abstract}

small volumes of acid influx. Water with alkalinity less than $20 \mathrm{mg} / \mathrm{L}$ is susceptible to rapid changes in $\mathrm{pH}$. Alkalinity values of $20 \mathrm{mg} / \mathrm{L}$ or more are generally recommended for freshwater aquatic life. Some components of alkalinity, such as carbonate and bicarbonate, can react with some toxic heavy metals and reduce their toxicity (U.S. Environmental Protection Agency, 1976, p. 7). 




Table 10.6-1 Dissolved-alkalinity concentrations at 13 sites

\begin{tabular}{|c|c|c|c|c|}
\hline \multirow{2}{*}{$\begin{array}{l}\text { Map } \\
\text { site } \\
\text { No. }\end{array}$} & \multirow{2}{*}{$\begin{array}{l}\text { Number } \\
\text { of } \\
\text { samples }\end{array}$} & \multicolumn{3}{|c|}{$\begin{array}{l}\text { Dissolved alkalinity } \\
\text { concentrations, in } \\
\text { milligrams per liter }\end{array}$} \\
\hline & & Minimum & Average & Maximum \\
\hline 2 & 1 & 190 & 190 & 190 \\
\hline 3 & 2 & 31 & 70 & 110 \\
\hline 5 & 53 & 73 & 159 & 230 \\
\hline 6 & 2 & 170 & 180 & 190 \\
\hline 9 & 2 & 70 & 180 & 290 \\
\hline 11 & 14 & 60 & 139 & 249 \\
\hline 14 & 1 & 32 & 32 & 32 \\
\hline 16 & 1 & 29 & 29 & 29 \\
\hline 21 & 2 & 34 & 72 & 110 \\
\hline 22 & 1 & 170 & 170 & 170 \\
\hline 24 & 13 & 31 & 101 & 195 \\
\hline 28 & 2 & 50 & 85 & 120 \\
\hline 31 & 14 & 24 & 104 & 170 \\
\hline
\end{tabular}

10.0 SURFACE-WATER QUALITY--Continued 10.6 Alkalinity 


\title{
10.0 SURFACE WATER QUALITY--Continued \\ 10.7 Trace Elements and Other Constituents
}

\section{OTHER CHEMICAL CONSTITUENTS ARE PRESENT}

\author{
Concentrations of 11 trace elements and other water-quality constituents were \\ determined for streams in the area. Only chloride exceeded \\ the criterion of $\mathbf{2 5 0}$ milligrams \\ per liter for domestic water supplies.
}

Many water-quality constituents and other trace elements have been measured in the study area. Nickel, copper, zinc, chromium, and cadmium are commonly found in very low (trace) concentrations in natural river waters but usually occur at or below detection limits. These elements along with calcium, chloride, fluoride, potassium, magnesium, and boron have been analyzed in samples from area streams. The ranges of concentrations of these constituents are shown in figure 10.7-1.

Water-quality criteria set maximum concentrations for the following trace elements in domestic water supplies: Cadmium, 10 micrograms per liter ( $\mu \mathrm{g} / \mathrm{L}$ ); chromium, $50 \mu \mathrm{g} / \mathrm{L}$; copper, $1,000 \mu \mathrm{g} / \mathrm{L}$; and zinc, $5,000 \mu \mathrm{g} / \mathrm{L}$ (U.S. Environmental Protection Agency, 1976). None of the measured concentrations exceeded these levels. Copper and zinc in river waters may be derived from natural sources or from industrial and domestic wastes. Chromium in stream water is commonly from industrial wastes (Hem, 1970). Many trace elements are necessary as micronutrients for plant or animal growth but may be toxic at high concentrations.

Chloride is the only ion that exceeded its criterion for domestic water supply, 250 milligrams per liter $(\mathrm{mg} / \mathrm{L})$, (U.S. Environmental Protection Agency, 1976, p. 205). The maximum chloride concentration in 489 samples from 15 sites was 400 $\mathrm{mg} / \mathrm{L}$.

Boron is an essential element for the growth of plants. The maximum concentration of $110 \mu \mathrm{g} / \mathrm{L}$ of boron was well within the criterion of $750 \mu \mathrm{g} / \mathrm{L}$ for long term irrigation on sensitive crops (U.S. Environmental Protection Agency, 1976, p. 25). 
Table 10.7-1 Ranges of concentrations of selected constituents at water-quality sites in Area 31






\title{
10.0 SURFACE-WATER QUALITY--Continued 10.8 Suspended Sediment
}

\section{SUSPENDED-SEDIMENT YIELDS EXCEED 300 TONS PER SQUARE MILE PER YEAR}

\author{
Suspended-sediment yield ranges from less than $\mathbf{5 0}$ to more than $\mathbf{3 0 0}$ tons \\ per square mile per year in Area 31. Clay- and silt-size particles \\ comprise 81 to 100 percent of the sediment.
}

\begin{abstract}
Suspended-sediment yields of streams in Area 31 for water year 1981 ranged from less than 50 tons per square mile per year $\left[\left(\right.\right.$ tons $\left.\left./ \mathrm{mi}^{2}\right) / \mathrm{yr}\right]$ in the southwest to more than $300\left(\right.$ tons $\left./ \mathrm{mi}^{2}\right) / \mathrm{yr}$ in the northeast (fig. 10.8-1) (Bonini and others, 1983, p. 27). The suspended-sediment yield is based on many factors including number of runoff events, rainfall intensity and duration, antecedent moisture conditions, temperature, ground cover, slope, and soil type. Because these factors vary, the yield varies also, as indicated from 4 years of suspended-sediment records for Little Wabash River at Louisville (table 10.8-1).
\end{abstract}

For the 11 sites sampled (fig. 10.8-1), suspended-sediment concentrations ranged from 4 to 2,320 milligrams per liter (mg/L); median concentrations ranged from 68 to $860 \mathrm{mg} / \mathrm{L}$ (table 10.8-2). The median concentration for 94 samples collected at these 11 sites was $281 \mathrm{mg} / \mathrm{L}$. None of these sites are affected by coal-mining activities.

Seven sites had only one sample; therefore, only a median value is shown. These samples are representative of a period of high rainfall-runoff. Three sites $(5,6$, and 31$)$ were sampled at various times from 1975 through 1981. Site number 11, Little Wabash River at Louisville, Illinois, was a daily suspended-sediment discharge site and has mean daily suspended-sediment discharge values available for the period 1978 through 1981 . The annual stream discharges and suspended-sediment loads and yields for this site are shown in table 10.8-1 for the period of record. The Office of Surface Mining Reclamation and Enforcement (1979) set the effluent limitations of suspended solids (sediments) from mined areas at $70 \mathrm{mg} / \mathrm{L}$ for any one time or an average of $35 \mathrm{mg} / \mathrm{L}$ for 30 consecutive discharge days. Only the minimum concentrations from streams sampled at low-flow conditions met these limitations.

Clay- and silt-size particles (finer than 0.062 millimeters sieve diameter) composed from 81 to 100 percent (median of 98 percent) of the suspended sediment in 29 samples collected at 10 sites in 1981 (fig. 10.8-2). Clay- and silt-size particles are carried in suspension at velocities lower than those required for larger sand-size particles.

Streamflow and land use were found to be the most significant factors affecting suspendedsediment concentration of streams in the coalmining region of southwestern Indiana (Wilber and others, 1981, p. 225). Average suspended-sediment concentrations were greater during high streamflow than during low streamflow, and they were greater in streams draining agricultural and mined watersheds than in streams draining forested watersheds. 


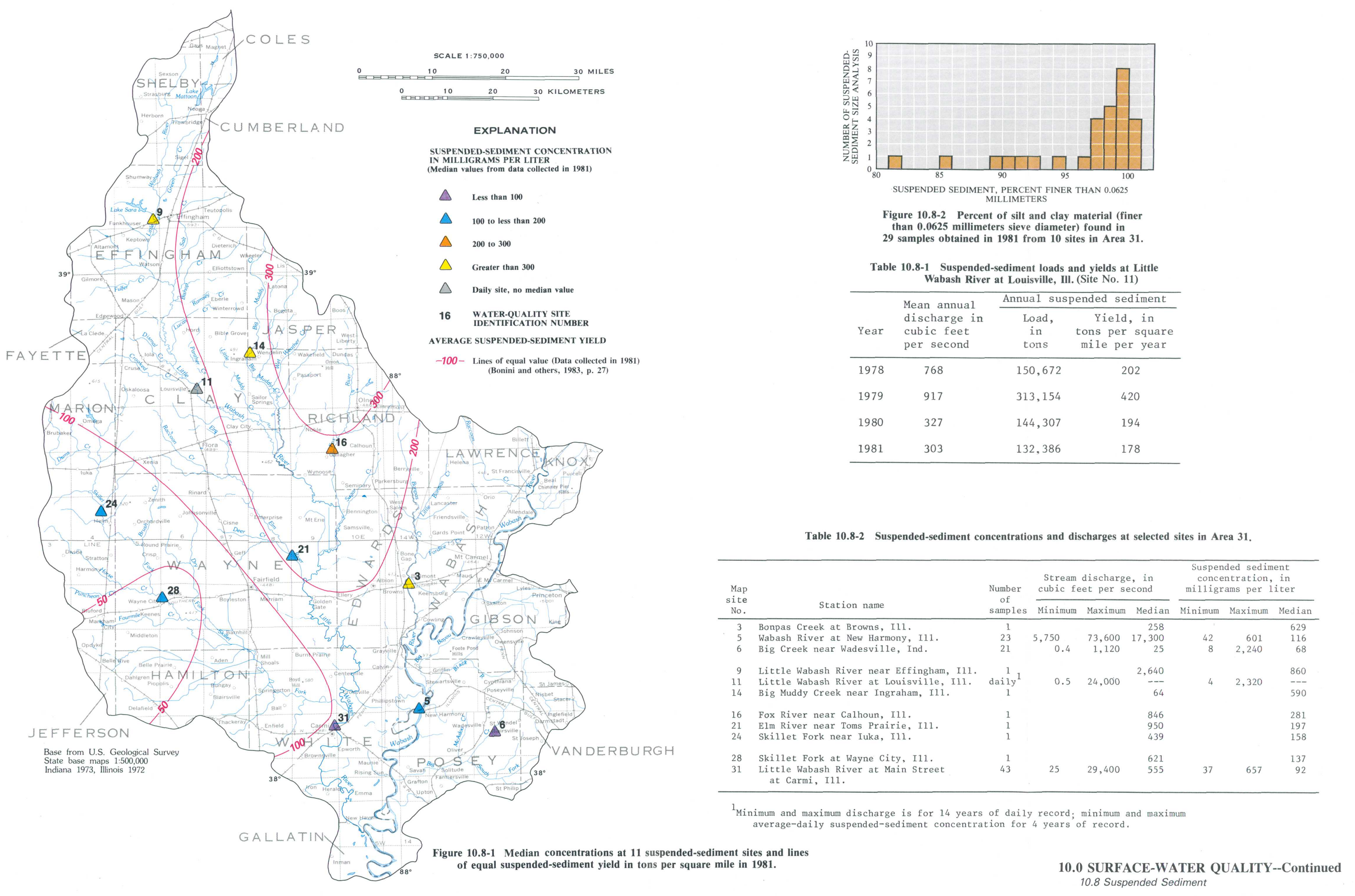




\title{
11.0 GROUND-WATER QUANTITY
}

\section{GROUND-WATER RESOURCES ARE AREALLY LIMITED}

\author{
Sand and gravel aquifers are thin or absent in most \\ of the area and bedrock aquifers generally \\ yield less than 10 gallons per minute.
}

Aquifers in Area 31 are glacial sand and gravel deposits and Pennsylvanian sandstone. Sand and gravel aquifers are present in bedrock valleys underlying major present-day streams, but are thin or absent in other parts of the area.

Sand and gravel aquifers along the Wabash River in White, Gallatin, and Posey Counties (fig. 11.0-1) are more than 15 feet thick and can yield more than 500 gallons per minute (gal/min) (Smith and Stall, 1975; Bechert and Heckard, 1966). Sand and gravel aquifers in the Little Wabash River valley in Effingham, Clay, and Wayne Counties can yield $100 \mathrm{gal} / \mathrm{min}$ or more. Other thinner sand and gravel aquifers can yield $20 \mathrm{gal} / \mathrm{min}$ or more.

The Pennsylvanian bedrock aquifers are the major sources of rural domestic supplies (Pryor,
1956). The Pennsylvanian System is the uppermost bedrock unit in the area. Its maximum thickness in the area is 2,200 feet (Willman and others, 1975), however, most wells obtain domestic supplies from the upper 300 feet. These uppermost strata of sandstone have higher yields than other strata within the Pennsylvanian System (Pryor, 1956, p. 24). Yields from wells in sandstone are usually less than $10 \mathrm{gal} / \mathrm{min}$.

A generalized hydrogeologic section (fig. 11.0-2) shows the relative positions of aquifers in the study area. Recharge to aquifers is primarily from precipitation. 

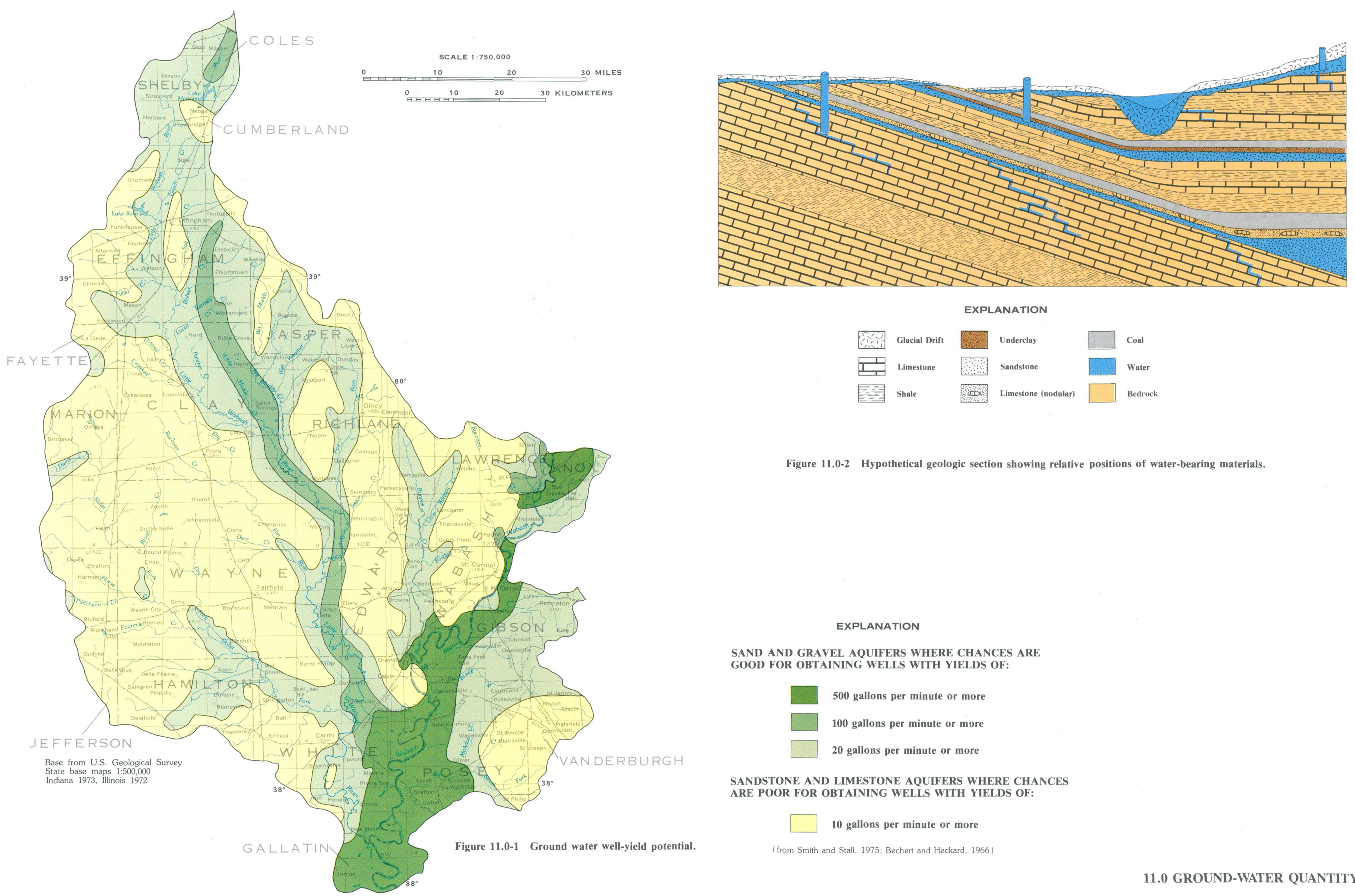

EXPLANATION

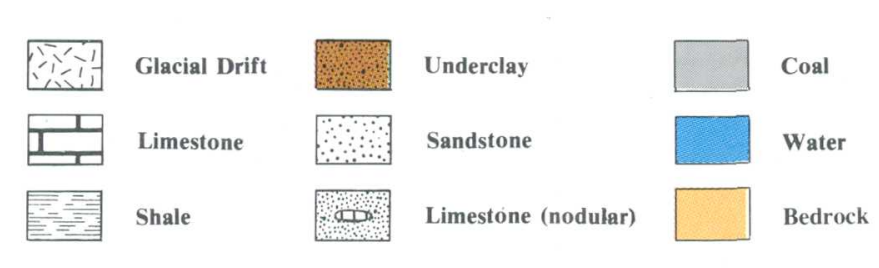

Figure 11.0-2 Hypothetical geologic section showing relative positions of water-bearing materials.

\section{EXPLANATION}

SAND AND GRAVEL AQUIFERS WHERE CHANCES ARE
GOOD FOR OBTAINING WELS WITH YIELDS OF:

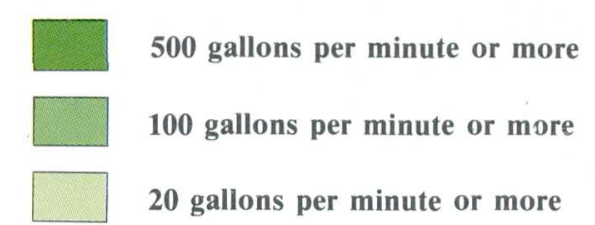

SANDSTONE AND LIMESTONE AQUIFERS WHERE CHANCES ARE POOR FOR OBTAINING WELLS WITH YIELDS OF:

10 gallons per minute or more

(from Smith and Stall, 1975; Bechert and Heckard, 1966) 


\title{
12.0 GROUND-WATER QUALITY
}

\section{GROUND WATER MAY NEED TREATMENT}

\author{
U.S. Environmental Protection Agency water-quality criteria \\ for public water supplies were not always met for \\ iron, manganese, chloride, and sulfate.
}

Analyses of water from 13 public supply wells in Area 31 are shown in table 12.0-1 along with U.S. Evironmental Protection Agency (1976) criteria for public water supplies. Iron and manganese criteria were not met in 80 percent of the water samples, and fluoride and sulfate criteria were not met in one sample.

Dissolved-solids concentrations ranged from 294 to 1,330 milligrams per liter $(\mathrm{mg} / \mathrm{L})$. The average concentrations of fluoride, chloride, sulfate, and dissolved solids were greater in water from sandstones than in water from unconsolidated deposits. Hardness ranged from 12 to $560 \mathrm{mg} / \mathrm{L}$. Water hardness is directly related to dissolved calcium and magnesium derived from dissolution of carbonates. Higher average concentrations of iron, manganese, and hardness are present in water from unconsolidated deposits than in sandstones (Larson, 1963, p. 10-28).

As water from precipitation infiltrates and moves through the ground-water flow system, it dissolves minerals. In general, the farther water moves from the area of recharge, the more mineralized it becomes (Gibb, 1973, p. 1). 
Table 12.0-1 Area 31 ground-water-quality concentrations, in milligrams per liter (data from Larson, 1963).

\begin{tabular}{|c|c|c|c|c|c|c|c|}
\hline Aquifer & Iron & Manganese & Fluoride & Chloride & Sulfate & Hardness & $\begin{array}{c}\text { Dissolved } \\
\text { Solids }\end{array}$ \\
\hline \multicolumn{8}{|l|}{ Unconsolidated } \\
\hline Maximum & 6.0 & 0.30 & 0.70 & 34 & 273 & 560 & 863 \\
\hline Minimum & 0.30 & 0 & 0 & 4 & 1 & 260 & 294 \\
\hline Median & 2.0 & 0.20 & 0.30 & 10 & 48 & 340 & 440 \\
\hline Average & 2.3 & 0.14 & 0.26 & 14 & 68 & 360 & 451 \\
\hline \multicolumn{8}{|l|}{ Bedrock } \\
\hline Maximum & 3.2 & 0.2 & 3.0 & 144 & 200 & 380 & 1,330 \\
\hline Minimum & trace & 0 & 0.10 & 10 & 1 & 12 & 359 \\
\hline Median & 0.60 & trace & 0.20 & 20 & 55 & 270 & 619 \\
\hline Average & 0.87 & 0.06 & 0.77 & 45 & 71 & 230 & 709 \\
\hline $\begin{array}{l}\text { USEPA Domesti } \\
\text { Water-Supply } \\
\text { Criteria }\end{array}$ & 0.30 & 0.05 & 2.0 & 250 & 250 & None & None \\
\hline
\end{tabular}




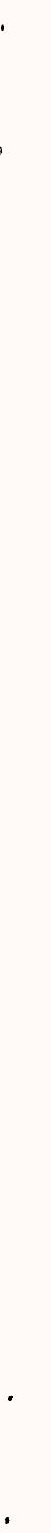




\title{
13.0 WATER-DATA SOURCES
}

\author{
13.1 Introduction
}

\section{NAWDEX, WATSTORE, OWDC, and STORET have Water-Data Information}

\author{
Water data are collected in coal areas by a large number of organizations in \\ response to a wide variety of missions and needs.
}

Three activities within the U.S. Geological Survey help identify and improve access to the vast amount of existing water data.

(1) The National Water-Data Exchange (NAWDEX) indexes the water data available from more than 400 organizations and serves as a central focal point to help those in need of water data to determine what information already is available.

(2) The National Water-Data Storage and Retrieval System (WATSTORE) serves as the central repository of water data collected by the U.S. Geological Survey and contains large volumes of data on the quantity and quality of both surface and ground waters.

(3) The Office of Water-Data Coordination (OWDC) coordinates Federal water-data acquisi- tion activities and maintains a "Catalog of Information on Water Data." To assist in identifying available water-data activities in coal provinces of the United States, special indexes to the catalog are being printed and made available to the public.

The U.S. Environmental Protection Agency operates a Water Quality Control Information System which includes a data base called STORET. This data base is used for the STOrage and RETrieval of data relating to the quality of water in waterways within and contiguous to the United States.

More detailed explanations of these four activities are given in sections $13.2,13.3,13.4$, and 13.5. 


\title{
13.0 WATER-DATA SOURCES--Continued 13.2 National Water-Data Exchange (NAWDEX)
}

\section{NAWDEX Simplifies Access to Water Data}

\author{
The National Water-Data Exchange (NAWDEX) is a nationwide program managed by \\ the U.S. Geological Survey to assist users of water data or water-related \\ data in identifying, locating, and acquiring needed data.
}

NAWDEX is a national confederation of wateroriented organizations working together to make their data more readily accessible and to facilitate a more efficient exchange of water data.

Services are available through a Program Office located at the U.S. Geological Survey's National Center in Reston, Virginia, and a nationwide network of Assistance Centers located in 45 States and Puerto Rico, which provide local and convenient access to NAWDEX facilities (see fig. 13.2-1). A directory (Edwards, 1980) is available on request that provides names of organizations and persons to contact, as well as addresses, telephone numbers, and office hours for each of these organizations is available on request (Josefson and Blackwell, 1982).

NAWDEX can assist any organization or individual in identifying and locating needed water data and referring the requestor to the organization that retains the data required. To accomplish this service, NAWDEX maintains a computerized Master Water-Data Index (fig. 13.2-2), which identifies sites for which water data are available, the type of data available for each site, and the organization retaining the data. A Water Data Sources Directory (fig. 13.2-3) also is maintained that identifies organizations that are sources of water data and the locations within these organizations from which data may be obtained. In addition NAWDEX has direct access to some large water-data bases of its members and has reciprocal agreements for the exchange of services with others.

Charges for NAWDEX services are assessed at the option of the organization providing the re- quested data or data service. Search assistance services are provided free by NAWDEX to the greatest extent possible. Charges are assessed, however, for those requests requiring computer cost, extensive personnel time, duplicating services, or other costs encountered by NAWDEX in the course of providing services. In all instances, charges assessed by NAWDEX Assistance Centers will not exceed the direct costs incurred in responding to the data request. Estimates of cost are provided by NAWDEX upon request and in all instances where costs are anticipated to be substantial.

For additional information concerning the NAWDEX program or its services contact:

Program Office

National Water-Data Exchange (NAWDEX) 421 National Center 12201 Sunrise Valley Drive Reston, VA 22092

Telephone: (703) 860-6031

or FTS 928-6031

Hours: 7:45 to $4: 15$ EST

or

NAWDEX ASSISTANCE CENTER
ILLINOIS
U.S. Geological Survey
Water Resources Division
Busey Bank County Plaza
102 East Main Street, 4th Floor
Urbana, IL 61801
Telephone (217) 398-5353
FTS 958-5353

Hours: $8: 00$ to $4: 30$ central time 


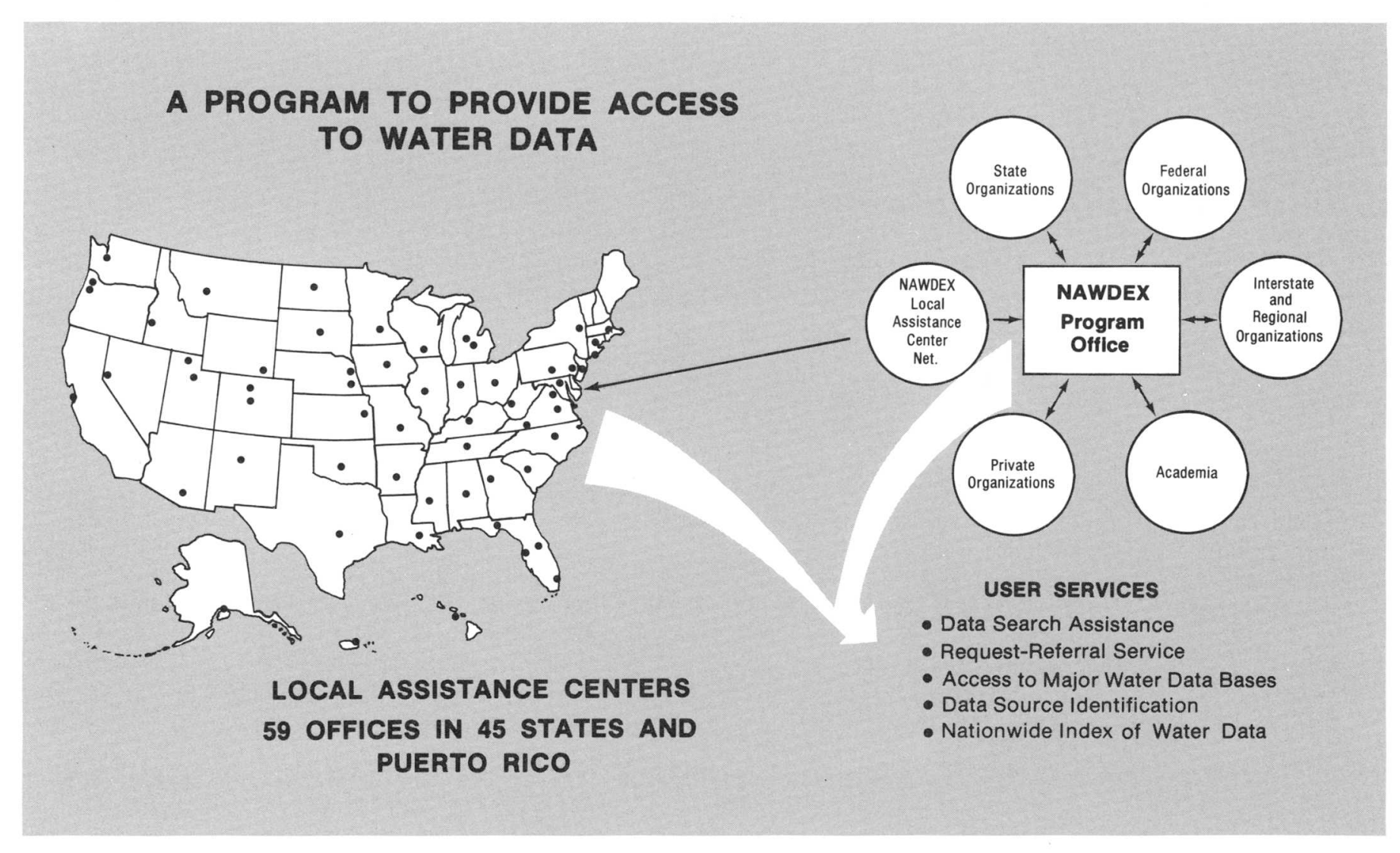

Figure 13.2-1 Access to water data.
MASTER WATER DATA INDEX

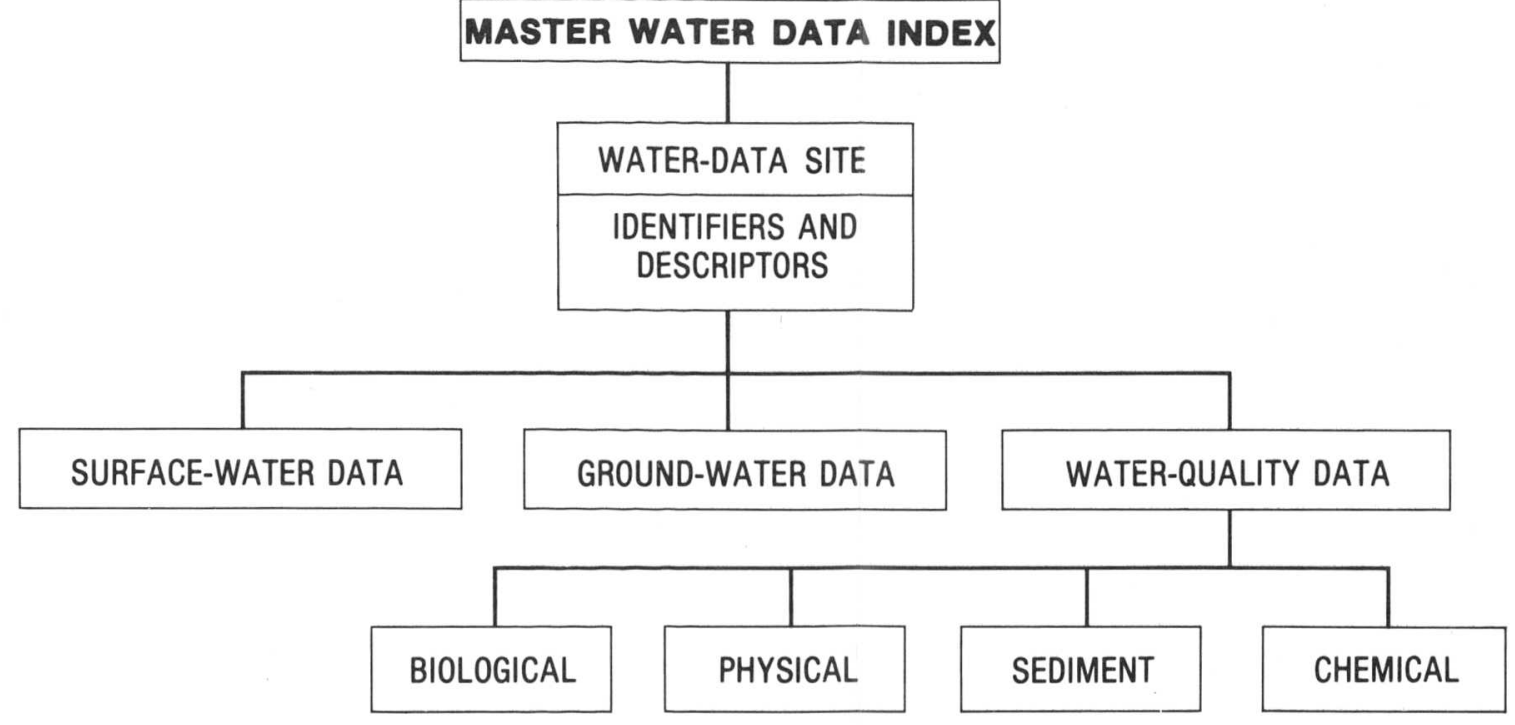

Figure 13.2-2 Master water-data index.

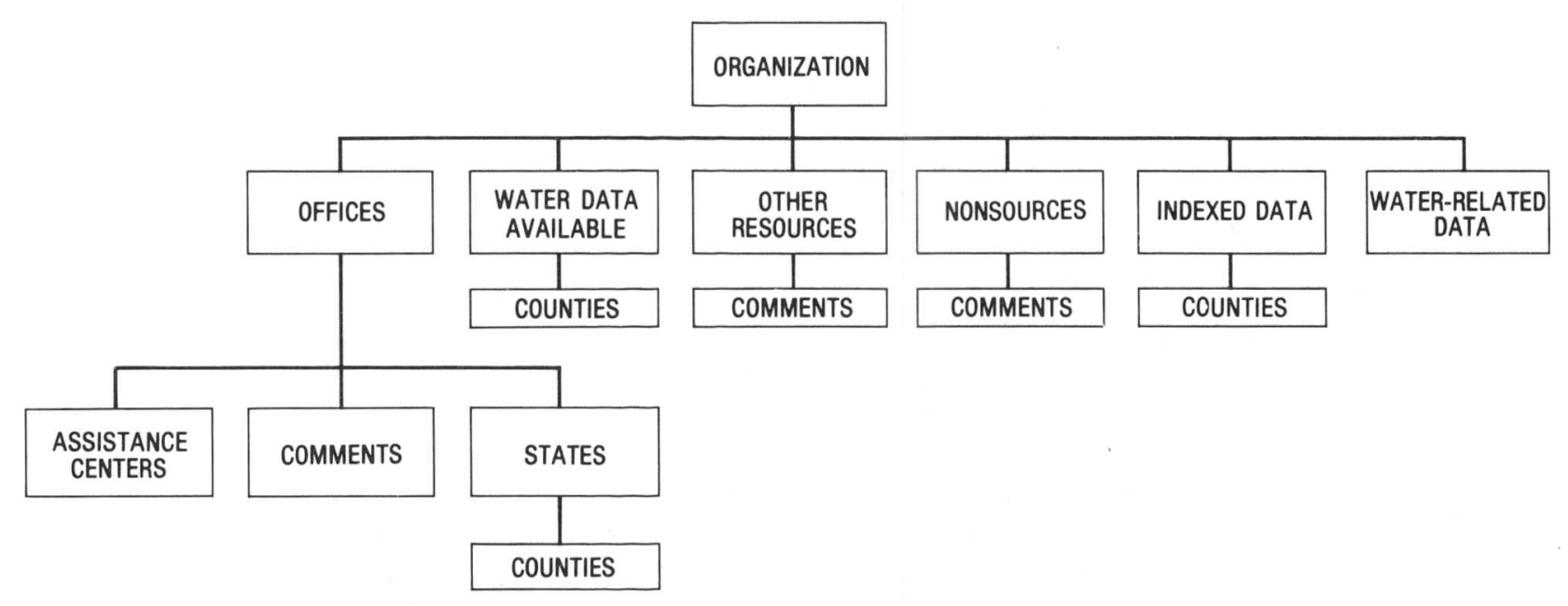

Figure 13:2-3 Water-data source directory. 


\title{
13.0 WATER-DATA SOURCES--Continued 13.3 WATSTORE
}

\section{WATSTORE Automated Data System}

\author{
The National Water-Data Storage and Retrieval System (WATSTORE) of the \\ U.S. Geological Survey provides computerized procedures and techniques \\ for processing water data and provides effective and efficient management \\ of data-releasing activities.
}

The National Water-Data Storage and Retrieval System (WATSTORE) was established in November 1971 to computerize the U.S. Geological Survey's existing water-data system and to provide for more effective and efficient management of its data-releasing activities. The system is operated and maintained on the central computer facilities of the Survey at its National Center in Reston, Virginia. Data may be obtained from WATSTORE through the Water Resources Division's 46 district offices. General inquiries about WATSTORE may be directed to:

\author{
Chief Hydrologist \\ U.S. Geological Survey \\ 437 National Center \\ Reston, VA 22092
}

or

\author{
U.S. Geological Survey \\ Water Resources Division \\ Busey Bank County Plaza \\ 102 East Main Street, 4th Floor \\ Urbana, IL 61801
}

The Geological Survey currently (1981) collects data at approximately 16,000 stream-gaging stations, 1,000 lakes and reservoirs, 5,200 surface-water quality stations, 1,000 sediment stations, 30,000 observation wells, and 12,500 ground-water quality wells. Each year many water-data collection sites are added and others are discontinued; thus, large amounts of diversified data, both current and historical, are amassed by the datacollection activities of the Survey.

The WATSTORE system consists of several files in which data are grouped and stored by common characteristics and data-collection frequencies. The system is designed to allow for the addition of data files as needed. Files are maintained for the storage of (1) surface-water, quality-of-water, and ground-water data measured on a daily or continuous basis; (2) annual peak values for streamflow stations; (3) chemical analyses for surface- and ground-water sites; (4) water parameters measured more frequently than daily; and (5) geologic and inventory data for ground-water sites. In addition, an index file of sites for which data are stored in the system is also maintained (fig. 13.3-1). A brief description of each file is as follows.

Station Header File: Information pertinent to the identification, location, and physical description of nearly 220,000 sites are contained in this file. All sites for which data are stored in the Daily Values, Peak Flow, Water Quality, and Unit Values files of WATSTORE are indexed in this file.

Daily-Values File: All water-data parameters measured or observed either on a daily or on a continuous basis and numerically reduced to daily values are stored in this file. Instantaneous measurements at fixed-time intervals, daily mean values, and statistics such as daily maximum and minimum values also may be stored. This file currently contains more than 200 million daily values including data on streamflow, river stages, reservoir contents, water temperatures, specific conductance, sediment concentrations, sediment discharges, and ground-water levels.

Peak-Flow File: Annual maximum (peak) streamflow (discharge) and gage height (stage) values at surfacewater sites comprise this file, which currently contains more than 400,000 peak observations.

Water-Quality File: Results of more than 1.4 million analyses of water samples are contained in this file. These analyses contain data for as many as 185 different constituents and physical properties that describe the chemical, physical, biological, and radiochemical characteristics of both surface and ground waters.

Unit-Values File: Water parameters measured on a schedule more frequent than daily are stored in this file. Rainfall, stream discharge, and temperature data are examples of the types of data stored in the Unit Values File.

Ground-Water Site-Inventory File: This file is main- 
tained within WATSTORE independent of the files discussed above, but it is cross-referenced to the WaterQuality File and the Daily-Values File. It contains in ventory data about wells, springs, and other sources of ground water. The data roluded are site location and construction history, and one time onsite measurements such as water temperature. The file is designed to accommodate 270 data elements and currently contain data for nearly 780,000 sites.

All data files of the WATSTORE system are main tained and managed on the central computer facilities However, data may be entered into and retrieved from WATSTORE at a number of locations that are part of nationwide telecommunication network.

Remote-Job Entry Sites: Almost all Water Resource Division's district offices are equipped with high-spee computer terninals for rals allow eass the WATs isto or retrieve data from the system within an interva of several minutes to overnight, depending upon the priority placed on the request. The number of remote jobentry sites is increased as the need arises.

Digital-Transmission Sites: Digital recorders are used at many field locations to record values for temperature, turbidity, wind direction, and chloride concentration. Data are recorded on 16-channel paper tape; the tape is removed from the recorder, and the data are transmitted over telephone lines to the receiver at Reston, Va. The data are re-recorded on magnetic tape for use on the central computer. Extensive testing of satelite data-collection plattorms indicates their a national scale. Battery-operated radios are used as the communication link to the satellite. About 500 data-relay stations are being operated currently (1983) by the Water Resources Division.

Central Laboratory System: The Water Resource Centrol Laboratory System: The Water Resorces laboratory are equipped to automatically perform chemical analyses ranging from determinations of simple inorganic substances, such as chloride, to complex organic compounds, such as pesticides. As each analysis is completed, the results are verifed by laboratory personnel and transmitted wia a conputer terminal to the Q

Water data are used in many ways by decisionmakers for the management, development, and monitoring of our water resources. In addition to its data processing, storage, and retrieval capabilities, WATSTORE can provide a variety of useful products ranging from simple tables of data to complex statistical analyses. A minimal fee, plus the actual computer cost incurred in

Computer-Printed Tables: Users most often request data from WATSTORE in the form of tables printed by the computer. These tables may contain lists of actual data or condensed inderes that indicate the availability of data stored in the files. A variety of formats is

Computer-Printed Graphs: Computer-printed graphs for the rapid analysis or display of data are another capability of WATSTORE. Computer programs are available to produce bar graphs (histograms), line graphs, frequency-distribution curves, X-Y point plots, siteine printers.

Statistical Analyses: WATSTORE interfaces with a package called SAS (Statistical Analysis System, 1976) to provide extensive analyses of data such as regression analyses, analysis of variance, transformations, and correlations.

Digital Plotting: WATSTORE also makes use of software systems that prepare data for digital plotting on
peripheral offline plotters available at the central computer site. Plots that can be obtained include hydrographs, frequency-distribution curves, X.Y point
plots, contour plots, and three-dimensional plots.

Data in Machine-Readable Form: Data stored in for use on other computers or for use as input to userwritten computer programs. These data are available in the standard format of the WATSTORE system or in the form of punched cards or card images on magnetic tape.

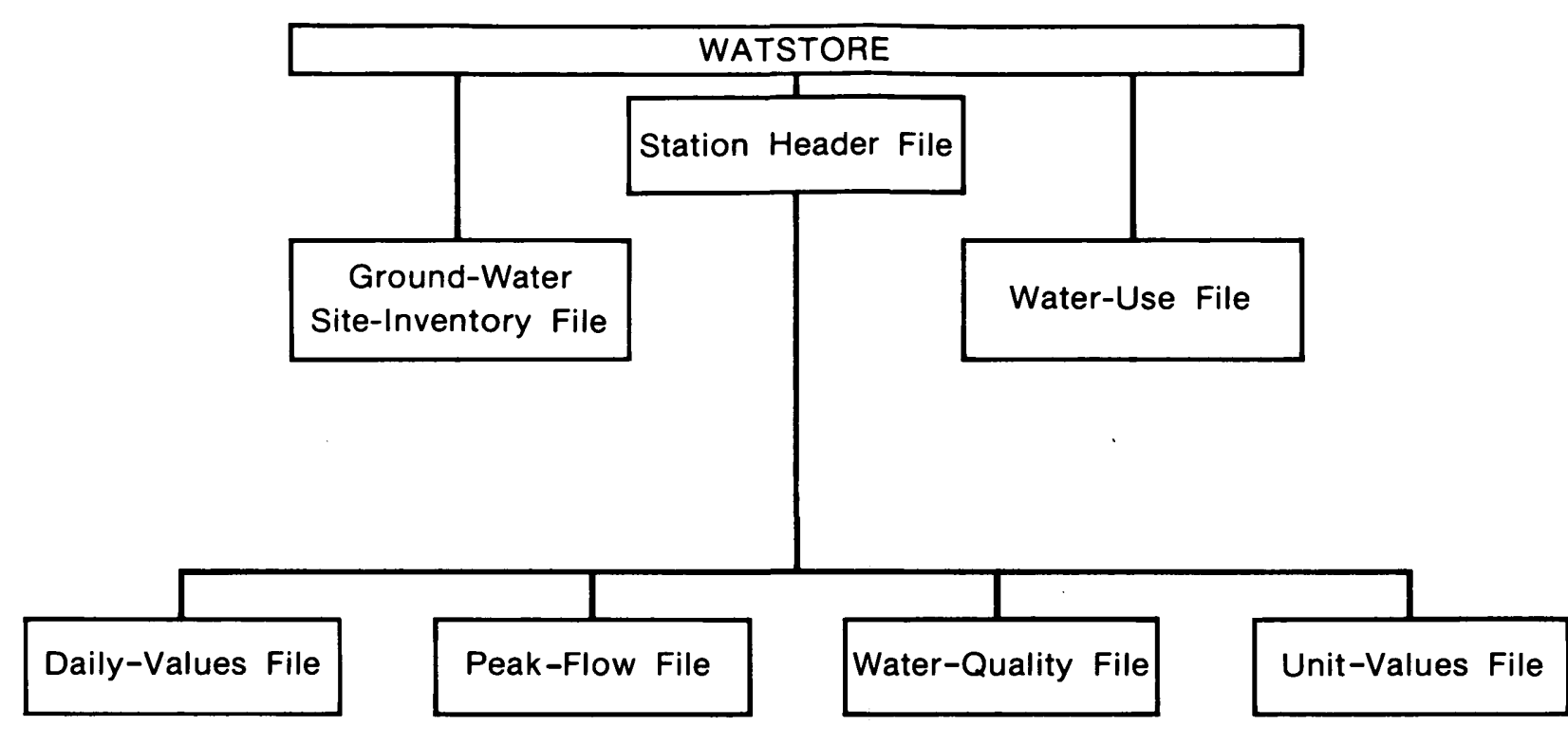

Figure 13.3-1 Index file of stored data. 


\author{
13.0 WATER-DATA SOURCES--Continued \\ 13.4 Index to Water-Data Activities in Coal Provinces
}

\title{
Water Data Indexed for Coal Provinces
}

\author{
A special index, "Index to Water-Data Activities in Coal Provinces of the \\ United States," has been published by the U.S. Geological Survey's Office \\ of Water Data Coordination (OWDC).
}

The "Index to Water-Data Activities in Coal Provinces of the United States" was prepared to provide information on the availability of waterresources data in the major coal provinces of the United States for people developing, managing, and regulating the coal resources of the Nation. It is derived from the "Catalog of Information on Water Data," which is a computerized information file about water-data acquisition activities in the United States, and some other countries. The index consists of five volumes (fig. 13.4-1): volume I, Eastern Coal province; volume II, Interior Coal province; volume III, Northern Great Plains and Rocky Mountain Coal provinces; volume IV, Gulf Coast Coal province; and volume V, Pacific Coast and Alaska Coal provinces. The volumes presented aid the user in obtaining data for evaluating the effects on coal mining on water resources and in developing plans for meeting additional water-data needs.

Each volume of this special index consists of four parts: Part A, Streamflow and Stage Stations; Part B, Quality of Surface-Water Stations; Part C, Quality of Ground-Water Stations; and Part D, Areal Investigations and Miscellaneous Activities. Information given for each activity in Parts A-C includes: (1) The identifiecation and location of the station, (2) the major types of data collected, (3) the frequency of data collection, (4) the form in which the data are stored, and (5) the agency or organization reporting the activity. Part D summarizes areal hydrologic investigations and water-data activities not included in the other parts of the index. The agencies that submitted the information, agency codes, and the number of activities reported by type are listed in a table.

Assistance in obtaining additional information from the Catalog file or who need assistance in obtaining water data can contact the National WaterData Exchange (NAWDEX) (See section 13.2).

Further information on the index volumes and their availability may be obtained from:

\author{
U. S. Geological Survey \\ Water Resources Division \\ Busey Bank County Plaza \\ 102 East Main Street, 4th Floor \\ Urbana, IL 61801 \\ Telephone: (217) 398-5353
}

FTS 958-5353

or

Office of SurfaceMining, Region III

U. S. Department of the Interior

U. S. Court and Post Office Building 46 East Ohio Street

Indianapolis, IN 46204

Telephone: (317) 269-2631

FTS 331-2600 


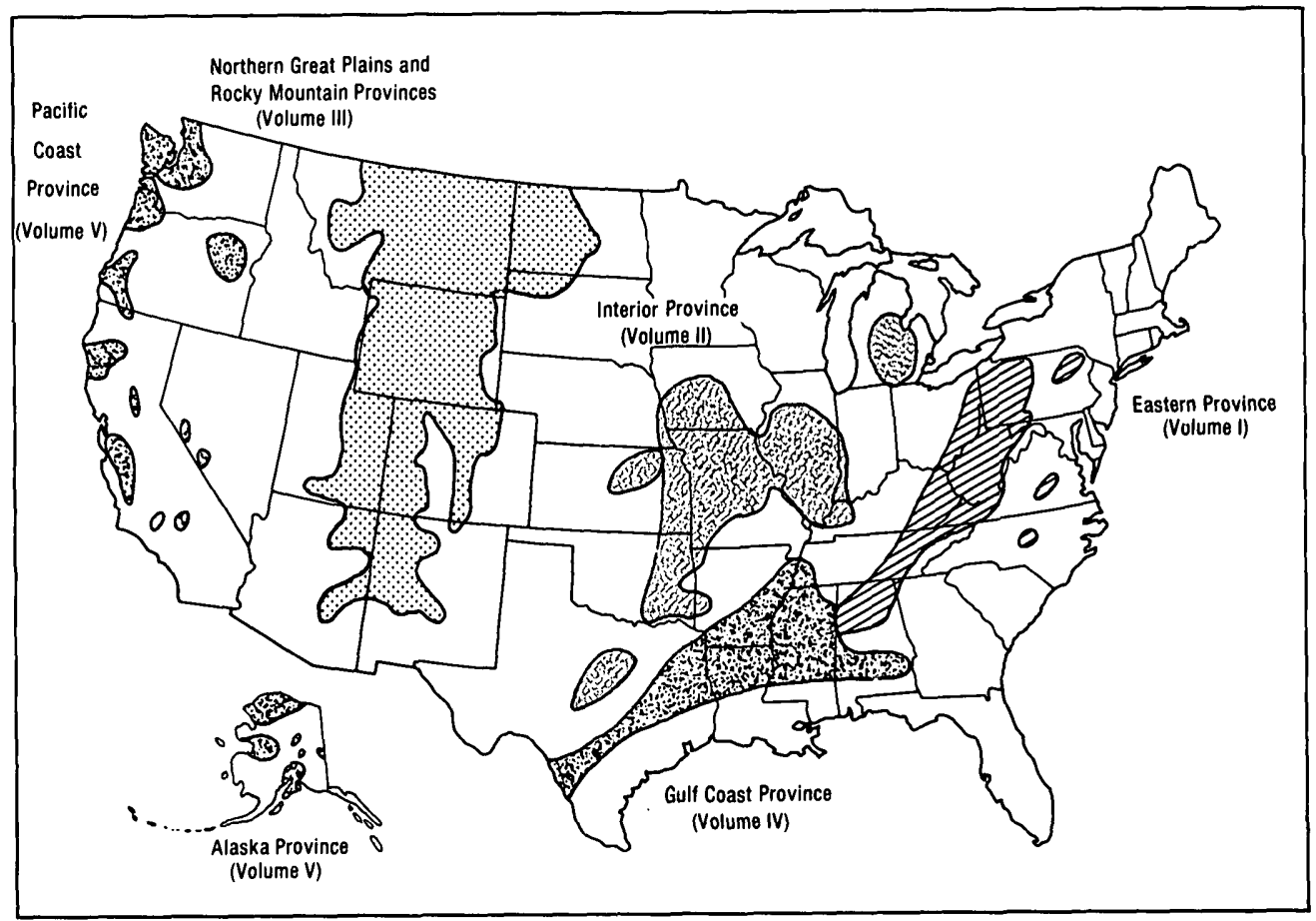

Figure 13.4-1 Index volumes and related provinces. 


\title{
13.0 WATER-DATA SOURCES--Continued 13.5 STORET
}

\section{STORET is U.S. Environmental Protection Agency Computerized Water-Data System}

\begin{abstract}
STORET is the computerized water-data system that is maintained by the U.S. Environmental Protection Agency; the system is used to store many kinds of water-quality data.
\end{abstract}

STORET is a computerized water-data system maintained by the U.S. Environmental Protection Agency (USEPA) for the STOrage and RETreival of data relating to the quality of water in waterways within and contiguous to the United States. The system is used to store data on water quality, water-quality standards, point sources of pollution, pollution-caused fish kills, waste-abatement needs, implementation schedules, and other water-quality related information. The Water Quality File (WQF) is the most widely used file.

The data in the WQF is collected through cooperative programs involving the Environmental Protection Agency, State water pollution control authorities, and other governmental agencies. The U.S. Forest Service, the U.S. Army Corps of Engineers, the U.S. Bureau of Reclamation, and the Tennessee Valley Authority all use STORET's WQF to store and retrieve data collected through their water-quality monitoring programs. Data from the U.S. Geological Survey's water-quality file in WATSTORE are automatically copied into STORET on a periodic basis.

There are 1,800 water-quality parameters defined within STORET's WQF. In 1976 data from more than 200,000 unique collection points in the United States were stored in the system. The groups of parameters and number of observations that are in the WQF are shown in figure 13.5-1.

State, Federal, interstate, and local government agencies can become STORET users. Information on becoming a user of the system can be obtained by contacting the EPA. The contact for Region $\mathrm{V}$ is:

$$
\begin{gathered}
\text { Director } \\
\text { Surveillance and Analysis Division } \\
\text { Environmental Protection Agency } \\
\text { 230 S. Dearborn Street } \\
\text { Chicago, IL } 60604
\end{gathered}
$$
(312) 353-6738
Source: Handbook, Water Quality Control Information System (STORET), U.S. Environmental Protection Agency, Office of Water and Hazardous Materials, Washington, D.C. 20460.




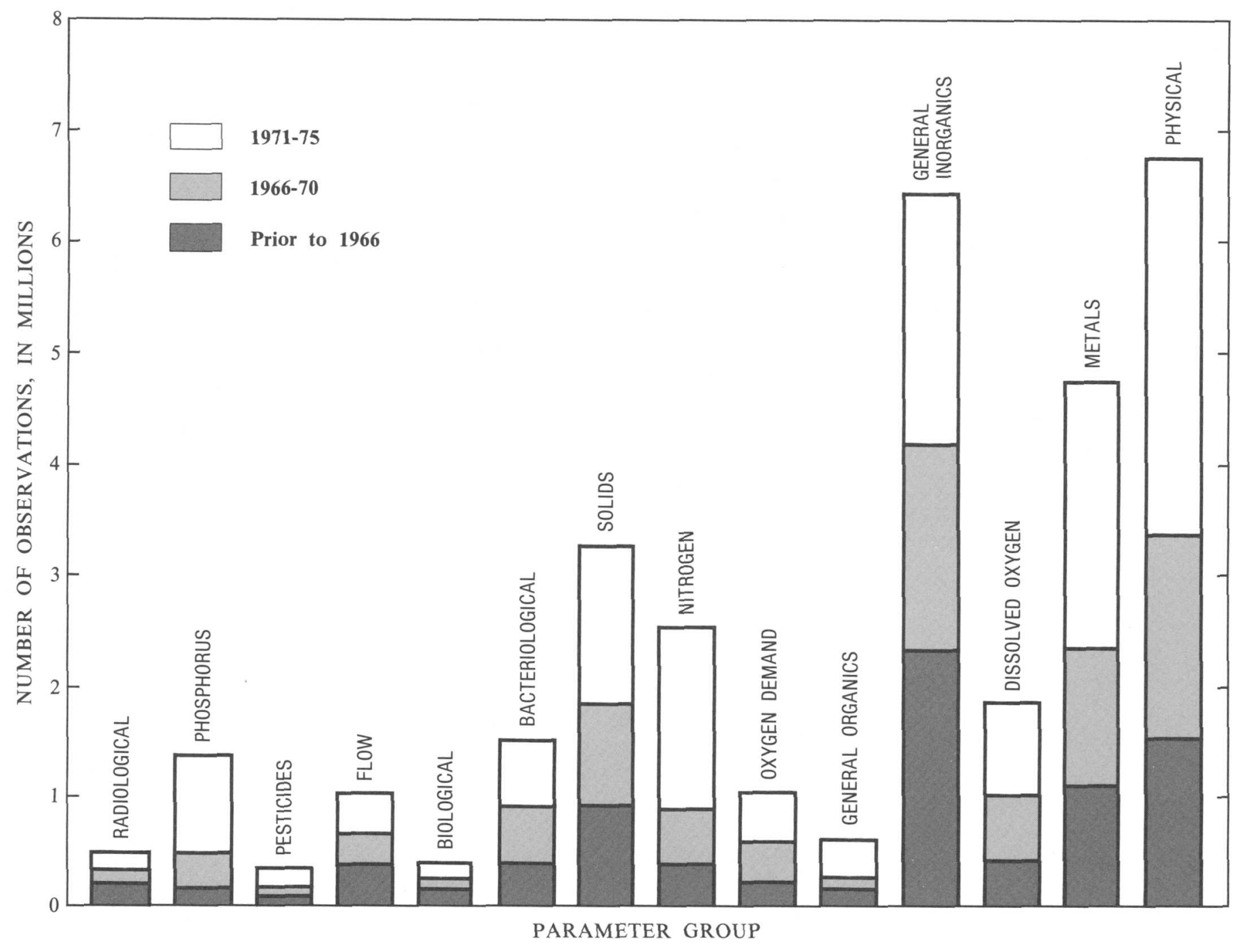

Figure 13.5-1 Groups of physical and chemical properties and number of observations in the Water Quality File (from STORET User Handbook). 


\subsection{LIST OF REFERENCES}

Andros, S. D., 1915, Coal mining in Illinois: Illinois State Geological Survey Coal Mining Investigation Bulletin 13, 250 p.

Bechert, C. H., and Heckard, J. M., 1966, Ground water, in Lindsey, A. A. ed., Natural features of Indiana: Indiana Academy of Science and Indiana State Library, p. 100-115.

Bonini, A. D., and others, 1983, Statewide instream sediment monitoring program for Illinois: Annual report-water year 1981 (excluding appendix B): Illinois State Water Survey Contract Report 318A, $45 \mathrm{p}$.

Curtis, G. W., 1977, Technique for estimating magnitude and frequency of floods in Illinois: U.S. Geological Survey Water-Resources Investigations 77-117, $70 \mathrm{p}$.

Dawes, J. H., and Terstriep, M. L., 1966, Potential surface water reservoirs of south-central Illinois: Illinois State Water Survey Report of Investigation 54, $119 \mathrm{p}$.

Edgar, Jim, ed., 1982, Illinois blue book, 1981-1982: Springfield, $656 \mathrm{p}$.

Fehrenbacher, J. B., Walker, G. O., and Wascher, H. L., 1967, Soils of Illinois: University of Illinois College of Agriculture, Agricultural Experiment Station, Urbana, Ill., Bulletin 725, 47 p.

Frederick, R. H., Myers, V. A., and Auciello, E. P., 1977, Five-to-sixty minute precipitation frequency for the eastern and central United States: National Oceanic and Atmospheric Administration Technical Memorandum NWS HYDRO-35, 36 p.

Gibb, J. P., 1973, Water quality and treatment of domestic ground-water supplies: Illinois State Water Survey Circular 118, $17 \mathrm{p}$.

Gray, H. H., Wayne, W. J., and Wier, C. E., 1970, Regional geologic map no. 3, Vincennes quadrangle: Indiana Department of Natural Resources, Geological Survey, scale 1:250,000.

Hem, J. D., 1970, Study and interpretation of the chemical characteristics of natural water: U.S. Geological Survey Water-Supply Paper 1473, 363 p.

Herschfield, D. M., 1961, Rainfall frequency atlas of the United States: U.S. Weather Bureau Technical Paper No. 40, 115 p.

Holhubner, E. G., and Fehrenbacher, J. B., 1972, Soil survey of Edwards and Richland Counties, Illinois: U.S. Department of Agriculture, Soil Conservation Service, in cooperation with Illinois Agricultural Experiment Station, Champaign, Ill., 84 p.

Illinois Conservation Needs Committee, 1970, Illinois soil and water conservation need inventory: Cooperative Extension Service, College of Agriculture, Univeristy of Illinois, Urbana, Ill.,
$192 \mathrm{p}$.

Illinois Department of Mines and Minerals, 1983, 1982 Annual coal, oil, and gas report: State of Illinois, Springfield, $342 \mathrm{p}$.

Illinois Environmental Protection Agency, 1976, Water quality management basin plan, phase I, Wabash River basin: Springfield, Chapter IV.

1978, Assessment and classification of $\mathrm{Il}$ linois lakes, volume 1: Water Quality Management Planning Program Staff Report, Planning and Standards Section, Division of Water Pollution Control, Springfield, $173 \mathrm{p}$.

Indiana Department of Natural Resources, 1982a, The 1980 survey of public water supply utilities in Indiana: Indianapolis, $68 \mathrm{p}$.

$1982 \mathrm{~b}$, The 1980 survey of domestic selfsupplied and livestock water uses in Indiana: Indianapolis, $13 \mathrm{p}$.

Indiana State Board of Health, Stream Pollution Control Board, 1980, Indiana State 208 water-quality management planning maps, regions $13 \mathrm{~A}$ and 13B: Indiana State Board of Health, Stream Pollution Control Board.

Josefson, B. M., and Blackwell, C. D., 1982, Directory of assistance centers of the National Water Data Exchange (NAWDEX): U.S. Geological Survey OpenFile Report 82-925, 31 p.

Kirk, J. R., Jarboe, Jacquelyn, Sanderson, E. W., Sasman, R. T., and Lonnquist, Carl, 1982, Water withdrawals in Illinois, 1980: Illinois State Water Survey Circular 152, $47 \mathrm{p}$.

Larson, T. E., 1963, Mineral content of public groundwater supplies in Illinois: Illinois State Water Survey Circular 90, $28 \mathrm{p}$.

Lewis, J. W., ed., 1972, Illinois blue book: Springfield, $856 \mathrm{p}$.

Lineback, J. A., 1979, Quaternary deposits of Illinois map: Illinois State Geological Survey, scale $1: 500,000$.

Meeks, W. C., revised by Dempster, G. R., Jr., 1983, Instructions for daily values file, daily values statistics (Program A969), in Hutchison, N. E., Compiler, 1975, WATSTORE user's guide, v. 1: U.S. Geological Survey Open-File Report 75-426, p. G1-G39.

Mitchell, W. D., 1957, Flow duration of Illinois streams: Illinois Department of Public Works and Buildings, Division of Waterways, $189 \mathrm{p}$.

Nawrot, J. R., Klimstra, W. D., Jenkusky, S. M., and Hickmann, T. J., 1980, Illinois State reclamation plan for abandoned mined land, resource document: Cooperative Wildlife Research Laboratory, Southern Illinois University, Carbondale, Ill., 254 p.

Nance, R. B., and Treworgy, C. G., 1981, Strippable coal 
resources of Illinois, Part 8-central and southeastern counties: Illinois Geological Survey Circular 515, 32 p.

Office of Surface Mining Reclamation and Enforcement, 1979, Surface coal mining and reclamation operations, permanent regulatory program: Federal Register, v. 44, no. 50, book 3, 153 p.

Patton, J. B., 1956, Geologic map of Indiana: Indiana Geological Survey, scale, 1:1,000,000.

Piskin, Kemal, and Bergstrom, R. E., 1975, Glacial drift in Illinois-thickness and character: Illinois State Geological Survey Circular 490, 35 p.

Pryor, W. A., 1956, Ground-water geology in southern Illinois: Illinois State Geological Survey Circular 212, $25 \mathrm{p}$.

Rickert, D. A., Ulman, W. J., and Hampton, E. R., 1979, Synthetic fuels development-Earth science considerations: U.S. Geological Survey Special Report, $45 \mathrm{p}$.

Sieber, C. R., 1970, A proposed streamflow data program for Illinois: U.S. Geological Survey Open-File report, $73 \mathrm{p}$.

Smith, W. H., and Stall, J. B., 1975, second printing 1977, Coal and water resources for coal conversion in Illinois: Illinois State Water Survey and Illinois State Geological Survey Cooperative Resources Report 4, $79 \mathrm{p}$.

Thornburn, T. H., 1963, Surface deposits of Illinois-a guide for soil engineers: University of Illinois Engineering Experiment Station Circular No. 80, Urbana, Ill., 135 p.

Toler, L. G.; 1982, Some chemical characteristics of mine drainage in Illinois: U.S. Geological Survey WaterSupply Paper 2078, 47 p.

Treworgy, C. G., and Bargh, N. H., 1982, Deep-minable coal resources of Illinois: Illinois State Geological Survey Circular 527, 65 p.

U.S. Department of Agriculture, 1977a, Soil associations of Indiana: Soil Conservation Service, in cooperation with Purdue University, Agricultural Experiment Station, Soil Associations Map, scale 1:500,000. 1977b, Prime farmland in Indiana: Soil Conservation Service, in cooperation with Purdue
University Agricultural Experiment Station, Prime Farmland Map, scale 1:500,000.

U.S. Environmental Protection Agency, 1976, Quality criteria for water: $256 \mathrm{p}$.

U.S. Geological Survey, 1975, Hydrologic unit map-1974, State of Illinois: Reston, Virginia, scale $1: 500,000$.

Van Den Berg, Jacob, and Elyn, J. R., 1981, Petroleum industry in Illinois, 1979: Illinois State Geological Survey, Illinois Petroleum 120, 132 p.

Walker, G. O., and Fehrenbacher, J. B., 1964, Soil survey of Wabash County, Illinois: U.S. Department of Agriculture, Soil Conservation Service, in cooperation with Illinois Agricultural Experiment Station, Champaign, Ill., 84 p., 23 plates.

Wallace, D. L., and Fehrenbacher, J. B., 1969, Soil survey of Gallatin County, Illinois: U.S. Department of Agriculture, Soil Conservation Service, in cooperation with Illinois Agricultural Experiment Station, Champaign, Ill., 136 p., 30 plates.

Wilber, W. G., Crawford, C. G., Renn, D. E., Ragone, S. E., and Wangsness, D. J., 1981, Preliminary assessment of the factors affecting water quality in the coal-mining region, southwestern Indiana, March to October 1979, in Warner, R. E., and Clark, P. E., eds., Water resources and land use management in Indiana, a symposium, Marshall, Ind., June 12-14, 1980, Proceedings: Indiana Water Resources Association, p. 215-234.

Willman, H. B., and others, 1967, Geologic map of Illinois: Illinois State Geological Survey, scale 1:500,000.

1975, Illinois stratigraphy: Illinois State Geological Survey Bulletin, 95, 261 p.

Wischmeier, W. H., and Smith, D. D., 1978, Predicting rainfall erosion losses-a guide to conservation planning: U.S. Department of Agriculture, Agriculture Handbook No. 537, 58 p.

Zuehls, E. E., Ryan, G. L., Peart, D. B., and Fitzgerald, K. K., 1981, Hydrology of Area 35, Eastern Region, Interior Coal Province, Illinois and Kentucky: U.S. Geological Survey Water-Resources Investigations Open-File Report 81-403, 68 p. 